The Effect of Shelf Space Positions on Perceived Brand's price and Quality: an Empirical Study on COOP \& Al Makhazen Stores in Lebanon

\author{
Dr. Nabila Abass \\ Associate Professor \\ Business Administration Department \\ Alexandria University
}




\title{
The Effect of Shelf Space Positions on Perceived Brand's price and Quality: an Empirical Study on COOP \& Al Makhazen Stores in Lebanon
}

\author{
Dr. Nabila Abass \\ Associate Professor \\ Business Administration Department \\ Alexandria University
}

\begin{abstract}
:
The aim of the current study is to investigate the preference of shelf space positions, with regard to two orientations (Vertical and Horizontal), as well as, investigating, the effect of shelf space position on the inferences of Brand's price and quality. This is tackled from the perspective of three groups of respondents (operations \& commercial department managers, customer and store managers)

Furthermore this study examines the differences among these groups with regard to the preferences of shelf space positions, as well as the meaning of different shelf space position (Vertical and Horizontal) with regard to the Brand's price and quality.

A pilot study was conducted to collect information about the Coop \& Almkhazen stores related to the company's store's number, items, sales and customers basket, as well as the manager's perception of planograms, the process of developing planograms and the information required to develop them.
\end{abstract}

The results of the pilot study indicate that the operations \& The commercial department managers are responsible for developing and producing planograms. The company purchased two software called SHELFLOGIC to help planogramers produce planograms for the 38 stores, so that the empirical study was applied on the Coop \& Almkhazen stores.

Based on the pilot study and the literature review the researcher developed a questionnaire, filled by 384 of the coop customers, 41 operations \& commercial department managers and 51 store managers.

The results of the ANOVA test regarding Horizontal orientation indicate that the three groups of respondents prefer Top positions over 
Central and Bottom positions, with no significant differences among them with this regard, furthermore the results indicate that the perceived price means reduced as brand positions moved from Top to Bottom, with no significant differences among them with this regards. Also perceived quality tracked those of price perception for store managers, but not for customers and operations and commercial department managers, these two groups believe that the brands that are placed on Central positions are of higher quality than those which are placed on Top and Bottom positions. For Horizontal orientation, the three groups of respondents prefers right positions, over Central and left positions with no significant differences among them with this regard, the results also indicate that the brand price means reducing from right to left for customers and store managers, but for operations \& commercial department managers the highest price mean is for Central position. The results also indicate that brands perceived quality means are reduced from right to left for store managers, the center of the array has the highest means for customers and operations \&commercial department managers. Finally, the results indicate that the effect of shelf space position on brand preference varies according to the brand in the product category. Recommendation for the Coop \& Almakhazen stores and other similar retail chains and future research directions are also presented.

Key words: planogram; shelf space positions; Vertical; Horizontal, price, quality. 


\section{Introduction:}

Aimed growing competition, retailers are increasingly interested in the effectiveness of their operations. They want to maximize the availability of products at minimal cost operations. Many studies were conducted on the promotional on shelf-availability, the most recent study by Ettouzoi et al. (2012) provides a framework to improve promotional on- shelf- availability, this framework includes eight causes affecting onshelf-availability, six of them are generic, that are forecasting, collaboration, replenishment, IT, distribution and production, the other two causes are specific to promotion, which are timescales and promotional process.

This issue is important because the study conducted by Grant and Fernlie (2008) found the $60 \%$ of customers will not purchase in store if confronted with out-of- stock (OOs), which affects the store profitability. Gray(2010) also found that the direct effect of more efficient and effective Backroom- to shelf replenishment contributes the overall retail store profitability. In addition to the availability of the products on shelves. The attractive presentation of shelves to attract customers, affects the sales and profitability. One of the marketing responsibilities is to design an attractive presentation, thus the amount of shelf space allocated to products is a primarily consequence of marketing decisions

Planograms represent plans of how retail products will be laid out on the shelves (Bai and Kendall, 2005) it determines the available shelf space for the operations. Planogram is a diagram, which is usually designed by Marketers and Retailers to define the shelf layout (Khan \& Asghar, 2010).

A Planogram contains important information for the execution of the operations, which includes the items in the assortment, the location of the items in the stores and the amount of space allocated to each item (Smith, 2011). The key characteristics of great Planogram include, customer-centric, operationally sound and financially viable (Smith, 2011).

Planogram is customer-centric when the space plan, with its assortment, grouping and placement techniques, is driven by a rich understanding of how customers shop, while still recognizing that patterns and emphasis often differ store by store.

Operationally sound, represents the strong consideration that must be given to empowering stores and supply chain, with space and information they need to implement and sustain the Planogram.

Empowering stores include ensuring new items that are available on the clearly defined rules of engagement around Planograms that are 
accurate and easy to interpret, thus capacities thus reflect consumer demand, an efficient replenishment method, and utilizing labor saving fixtures.

Financially viable reflects that the Planogram's sales and margins relative to the inventory and space must be consistent with the financial requirements for the category. The above discussion indicates the importance of Planogram integrity.

Planogram integrity is an important concept for marketers and retailers. It refers to the degree to which the Planograms are followed in practice, (Wonsel et al. 2006). High Planogram integrity occurs if the difference between Planogram and the actual situation is small. The differences between the actual realization and Planograms could be related to assortment differences, location differences, and facing differences (woensel et al. 2006). Assortment differences are related to the composition of the category, to add and drop items for the category will have an effect of the Planogram integrity. Location differences are related to the place in the self, where the item is on a different position than what is specified in the Planogram. Facing differences give an indicator whether the assigned facings are correct in the realized plans, and whether the correct side of the item is placed forward to the customer.

The results of the empirical study proposed by (woensel et al. 2006) demonstrate that the majority of differences relate back to facing differences, on the second and third place of importance. They could identify four main drivers for these differences the main drivers are as follows:

1-Local store management.

2-Different local circumstances than assumed in the Planograms.

3- A significant adoption time for change.

4- Lack of incentives for the headquarters.

According to (Woensel et al. 2006) the major consequences of a lack of Planogram integrity is a substantial loss of efficiency both in the marketing strategy as in the operational executions. The consequences of Planogram integrity are important for the efficiencies of marketing strategy as well as the operation execution. Planograms developed by marketers to increase or maintain the turnover, the deviation from the Planogram will lead to turnover reduction.

In conclusion, retail shelf space is an asset, improper location which might lead to delisting the product before it achieves its potential sales.

Space elasticity is the ratio of relative change in unit sales to relative change in shelf space. Space elasticity is used to measure the responsiveness of sales with regards to the change of allocated space 
(Curhan, 1972). Curhan (1973) found that the actual value of space elasticity can be different depending on the products; brands, stores; and in- store layout, this means that there are a lot of required information when specifying and changing shelf space, which is the focus of current study.

The objectives of the current study are to investigate the placement choices by brand (row and column preferences by brand), as well as the effect of shelf space position on the inferences of brand's price and quality from perspectives of different partners in retail supply chain (customers, store managers, operations \& commercial department managers). Furthermore the study aims to investigate the differences among these groups concerning the preference of shelf space positions as well as the meaning of different shelf space positions (Vertical and Horizontal) with regard to product price and quality.

The researcher conducted a pilot study, semi-structured interviews where carried out with the country managers, operations \& commercial department managers, and store managers. The interviews revealed that the COOP \& Al Makhazen stores have the following unique characteristics:

1-Amongst all supermarket chains in Lebanon, it is the biggest supermarket chain (38 stores). Appendix A-1 represents a list of the addresses and phone number of the 38 stores.

2-It is non demographic segregation, spread out all around Lebanese territories.

3- Diversity of stores type divided into 3 classes referring to the sales volume: class (A) stores, class (B) stores and class (C) stores.

4-By willing to be the most convenient stores from customer's point of view, the company builds each store entity (item file, layout, special offers) referring to its customer profile.

That is why the researcher applied the empirical study on the COOP \& Al Makhazen stores chain.

Current study may provide both practical and academic contribution as follows:

\section{Academic contribution:}

Results of the current study are expected to contribute to the growing literature on Planogram, by extending the investigation to a less developed country (Lebanon). However empirical research on the product shelf space positions and their relationship with product price and quality inferences, are somewhat limited, especially those which consider different partners in the retail supply chain (operations \& commercial department managers, store managers and customers). 


\section{Practical contribution:}

Many recent researches define supply chain management as integration of supply and demand processes within and across companies (Chen et al. 2009 a, b; Richey et al. 2010) this means that supply chains performance could be improved by the incorporation of market intelligence, that includes consumer demand information into supply side decision making (Nachmann et al, 2010), thus the coordination and collaboration within and across supply chain is very important, specially at the last hundred yards of supply chain, where retailers and customers interact, (Eroglu et al, 2010). Procter and Gamble refers to customer's retail shelf experience as the first moment of truth (Nelson and Ellison, 2005) because it represents the critical linkage between retail marketing management and supply chain management, so that customers, perspectives should be considered when developing the planogram.

Also Lindblom and Olkonen (2006) provided a new perspective on category management by examining the concept of power within manufacturer/retailer relationship. Their study revealed that manufacturer believe that retailers are clearly in charge of category management tactics, the large manufacturers possess relatively strong weight of control in category management decision making, whereas small manufacturer process little weight of control, thus at the practical level, current study will provide retailers with an effective Planogram to arrange the products in the stores, which will consider the perspectives of operations \& commercial department managers, stores managers, and customers. This will contribute to the asymmetric effect of preferences of the Vertical and Horizontal positions.

This may be an important contribution because when different stages in retail supply chain, customers, stores managers and operations \& commercial department managers' perspectives are consistent with each other in this regard, the inferences based on this schemas will represent conscious and controllable process and contribute to achieve Planogram integrity, which is very important for the effectiveness of marketing strategy as well as the operations executions. In addition, if the results will support the fact that they will extract the some meaning from different shelf space positions, the physical position of a product on the shelf should match its perceptual positioning, thus the result will help managers to specify the best shelf space position for each brand in the product category (by brand analysis). This may be an important contribution, specifically in the case of unsought or new brands. Moreover, the results will help retailers to develop the pricing strategy to 
charge premiums for specific space positions, and to convince manufactures to pay premiums for these positions, furthermore the result may help manufactures to make an efficient promotion (display) decisions.

To achieve the research objectives, current research is organized as follows. Section 2 surveys the relevant literature; section 3 represents the research problem; section 4 represents research objectives; section 5 describes the pilot study, section 6 represents the research methodology, which includes research hypothesis; research sampling and data collection procedures. Section 7 describes data analysis and hypothesis test and section 8 deals with research conclusion.

\section{Related and previous work:}

\subsection{The importance of retail Planogram:}

According to Rouse (2010) a retail Planogram is a diagram that shows how and where specific retail products should be placed on shelves or displayed in order to increase customer purchase.

Experienced Planogrammers develop these Planograms for different types of visual merchandising display (e.g. shelf- displays, pegboards, or slat board). Many retailers have adopted software programs (e.g. spaceman, Prospace), to develop planograms, the programs can display historical product sales, profits, and inventory turnover (Hansen et al. 2010).

Planograms should be developed based on the available information about the products (e.g. stock keeping unit numbers, product codes... etc).

Planogrammers make recommendations about the number of facings a certain products should have on a retail display, how high or low it should be on the display, and which products should surround it.

The Planogram used by the retail helpers that are hired to restack retail shelves and displays, thus it helps the managers of a retail stores or chain to control over the products display and to track and improve their Planograms.

Rettie and brewers (2000) suggested that customers' choice decisions are made at the point of sale with product placement influences the attractiveness of the offerings. Also Nelson and Ellison (2005) suggested that the position of the product is a crucial determinant of product choice. Simonson (1993), Simonson \& Tversky (1992), pointed out that different ways of presenting products in the store can modify the customer's choice. Simonson (1993) found that customers present a low probability of choosing the cheapest brand on the shelf when the product of the store category are organized according to design or variety Criteria 
instead of according to brand organization. The store brand sales may be higher if the dealer organized the shelf by brand.

Chen et al. (1999) emphasises the importance of store space allocation decision regarding the face of a deluge of new products and substantial profit opportunities through slotting allowances. Many prior researches on the effects of space on sales and others had shown that the space allocated has positive impact on product performance (Carins, 1963; Frank and Massy, 1970; Churhan, 1973; Corstjens and Dolyle, 1981; Bultez and Naert, 1988; Borin et al, 1994; Urban, 1998; Desmet and Renaudin, 1998). Suarez (2005) found direct relationship between the space occupation by store brands and the market share, and indirect relationship between the space and the price differential gap, the number of national brands and the range of choice.

Moreover many prior researches emphasized that as well designed shelf space allocation could help retailers to improve inventory return on investment and raise customer satisfaction, by reducing the likelihood of products being out- of - stock.

Shelf space allocation can also help retailers to improve the financial performance of store, increase profit margins and reducing manpower costs (Fanschers, 1991; yang and chen 1999; yang, 2001).

Efficient space management can also allow for better brand exposure which can encourage impulse buying (Levy and weitz, 1995; walter and Bommer, 1996). Space management provides retailers with an effective tool to implement mixed strategies that combine low cost with differentiation (Helms et al, 1992; Yang and Chen, 1999).

The traditional space management tool employed is a Planogram, which provides a shelf space layout of products and workable method by which merchandising plans can be communicated efficiently.

An effective Planograming helps in leveraging every inch of selling space available, and in capitalizing available data to achieve financial targets (Zufryden, 1986; Dreze et al, 1994; Borin et al, 1994; Yang, 2001). Gajjar and Adil (2010) proposed three heuristics to solve a shelf space allocation problem, the study found that the proposed heuristics are applied to a case of existing retail stores and gave more profit than the current allocation schema, which means that the planograms should be revised to improve the retail's performance.

\subsection{The effect of spatial positions of products on sales}

Shelf space allocation affects retail sales by stimulating demand (Koschat, 2008) minimizing stock out. It drives operating costs, such as inventory, labour and information processing, which affect the profitability of retail operation (Ratchford, 2003). Nierop, (2008) indicated that the allocation of scarce shelf space among stocked items 
are relevant issues for the retailer, it is an important determinant of sales and marketing effectiveness, revenue, costs and profit of the product category.

Many studies on product placement concluded that the spatial position of products effects consumers' inferences about prices (Inman et al. 1990), the number of product Comparisons that buyers make before purchasing (Breugelmans et al. 2000), the attention of the products or Brands (Chandon et al. 2007), the level of exposure and physical interaction with the products (Desmet and Renqudin, 1998).

Inconsistent effects have been noticed for other positions, these effects were an extreme position advantage (Nisbete and Wilson, 1997), Middle position advantage (Show, 2000), no position advantage (Chandon et al. 2007) and position advantages based on product category.

Dreze et al. (1994) investigated cross- products effect, the study found that complementary merchandizing resulted a positive boosts in sales, on tested products, shelves at eyesight level are more favorable than shelves located at the Top or Bottom of the shelf fixtures.

Valenzuela et al. (2006) conducted five experiments to examine customers beliefs regarding the price and quality of products based on their Vertical and Horizontal self space positions.

The results showed that consumers shared beliefs regarding the price of products based on their Vertical and Horizontal shelf space position. The Horizontality inferences were the right-hand-side. The price inferences translate into quality inferences and result in items in the Vertical and Horizontal centers (Middle- row and/ or column) being perceived as price/ quality trade off and being preferred.

The Verticality inference captures that higher priced products are in Top rows. The results suggested that Verticality effects are conscious, whereas Horizontality effects are non-conscious.

There are many quantitative models that have been proposed to describe the relationship between shelf space and sales. In Malsagne (1972) space is allocated in proportion to total sales.

Gifrino and Mckinsey (1963) assigned space in relation to direct product profit. Zafryden (1986) proposed a dynamic programming model for the shelf space allocation problem, the model took into account other factors such as price, store characteristics, advertising and promotion.

Shelf space allocation is related with many retailing problems, some integrated models have been proposed in this regards. Borin et al. (1994) could provide a sudation for product assortment and shelf space allocation. Urban (1998) integrated assortment, inventory control with a traditional shelf space allocation mode.

Bai et al. (2006) stated that these models usually involve a large number of parameters, and it was difficult to obtain a reliable estimation 
of these parameters. Yang (2001) proposed a simplified linear model, which includes the location effect of shelves on sales; the model was also difficult to be applied.

Bai et al. (2006) proposed two dimensional shelf space allocation model, the model added the right dimension to the shelf space allocation decisions, to the shelf length. It was more realistic when compared to the available models in the literature and the software currently used in retail practice. Based on the results of the empirical study for a real- life supermarket chain, the height dimension will improve shelf space utilization and sales. Irion et al. (2011) proposed a model for store shelf space allocation, their Methodology was illustrated on a real-life application where they predict a $22.33 \%$ increase in store profits if the model's solution is implemented.

Murray et al. (2010) developed a model that optimizes a retailer's decision for product prices, display facing areas, display orientations and shelf-space locations in a product category, their model considers both the width and height of each shelf, allowing products to be tracked, and allow retailers to consider product display areas and multiple display orientation, also their model allows joint decisions on both product allocation and price decisions, and captures cross-product interactions in demand through prices.

\section{Research problem:}

The effect of shelf space placement is very important to retail stores. Dreze et al. (1994) concluded that moving a product from the worst to the best Vertical position increased sales up to $40 \%$ and up to $15 \%$ for similar Horizontal movement.

Reviewing the available Planograms literature reveals that retail shelf space is an asset, improper location might lead to delisting the product before it achieve its potential sales. Shelf space placement helps retail mangers to control over the products display. The position of the product is an important determinant of product choice (Nelson and Ellison, 2005).

Many researches' results supported the effect of spatial positions of the products on consumer's inferences about prices (Iman et al. 1990), the attention of product demand (Chandon et al. 2007).

Consumers' choice decisions are made at the point of purchase, influenced by product placement, a well managed shelf space allows retailers to get more and more business from different stages in the supply chain (Eroglu and waller, 2011).

One of the key characteristics of good Planogram is that the Planogram is customer-centrice, which means that the space plan, with its 
assortment, grouping and placement techniques, is driven by a deep understanding of how customers shop, while still recognizing the patterns and emphasis which differ from store to store (smith, 2011).

The development of a great Planogram needs a lot of information about different stages of supply chain (e.g. manufacturer, store managers, operations managers and customers).

Reviewing related literature revealed that most of the studies were conducted in these developed countries. No studies have been conducted in this regard in Lebanon (to the researcher's knowledge). Moreover the previous studies have given considerable effort of product Vertical and Horizontal shelf space position and customer's believes about its price and quality, little have been done to include different supply chain partners' perspectives (customers, retail managers, operations managers, and commercial department managers).

Valenzuela et al. (2006) studied the difference between manufacturer and retail managers' beliefs regarding the prices and quality of the products based on their Vertical and Horizontal positions.

The interview that conducted with the COOP \& Al Makhazen stores country manager in the current study reveals that the operation $\&$ commercial department managers are responsible for developing the Planograms for the 38 stores of the COOP stores chain in Lebanon, depending on the information about numbering items, varieties and different size, sales, margin, profitability of the items store brands, other brands, stock keeping, unit number, product code, suppliers contractual agreements and the minimum and maximum size of Planograms. It also reveals that and the Planograms should be different from one store to another based on the available space at the store location, and the required items in each location.

Retail helpers use Planograms to restock retail shelves and displays under the supervision of store managers. Customers and store managers' perspectives are not considered when developing the Planograms. So current study attempts to examine the effect of different shelf space positions on the perception of brand's price and quality for operations \& commercial department managers who develop and produce Planograms, store managers who supervise the Planogram integrity and customers who purchase from stores and use shelf space positions as a source of information to inference price and quality. Furthermore, the study will measure the differences among these groups in this regards. 


\section{Research objectives:}

The current research aims to:

1- Contribute to Planogram literature from the prespective of a developing country (Lebanon).

2- Extend knowledge about Planogram importance in the COOP retail chain, in particular this study will investigate the following:

2-1-Shelf Space positions' preferences from the three groups of respondents' perspectives and the difference among them with this regard.

2-2-The difference among customers, operations \& commercial department managers and store managers with regard to the meaning of different shelf space positions (Vertical and Horizontal) with regard to products price and quality.

2-3- The placement choices by Brand (Row and Column preferences by brand) for customers, store managers, operations \& commercial department managers' perspective and the differences among them with this regard.

3- Provide recommendations to both operations \& commercial department managers, store managers regarding the development of an effective Planograms, which should confirm customers' expectations about the relationship between product shelf space positions and Brands' prices and quality as well as the ideal $2^{\text {nd }}$ best and worst positions for different brands in the product categories.

\section{Pilot Study:}

Semi-structured interviews were carried out with the Country manager, the operations \& commercial department managers and their assistants (14 managers) and store managers (10 managers) of the United Company for Central Markets "COOP". The objectives of the interviews are to collect information about the following:

1-The company's stores chain in different districts in Lebanon with regards to number of the items, sales volumes and customer basket.

2- The managers' perceptions of Planograms and its benefits to Corporate and stores.

3-The process of developing Planograms for different stores locations, the information required to develop them and the individuals who are responsible for developing the Planogram.

The results of the pilot study provide the following information:

1 - The total number of separate key unit SKUs is 28000 , while the total number of private label SKUs is 600 .

2-Recent data (2011) represents the number of customers, sales value + TVA and Basket + TV, for different Lebanese districts. Appendix A - 2 represents this data. 
3-The COOP operations managers define the Planogram as a schematic drawing of shelves and fixtures that help achieve optimal use of available shelf space at the COOP stores. They believe that they should drive their customers when developing and producing planograms.

4-Operations and commercial department managers are responsible for developing and producing the Planograms, the company purchased two software called SHELF LOGIC to help the Planogrammers producing Planograms. They make decisions about brands, products, items according to specified information (as mentioned before). The final Planogram signed off by the commercial department. The data and information obtained from the pilot study was used to develop the research hypothesis and questionnaire.

\section{Research Methodology}

\subsection{Research Hypotheses}

Based on the literature review on the meaning of product positions (Vertical, and Horizontal), and the interviews conducted with the COOP managers, which indicates that the store managers' role is to achieve Planogram integrity while the operations \& commercial department managers' role is to maximize product category sale and customers expect to infer brands' price and quality, so that the researcher propose the research hypotheses for the two orientations as follows:

\subsubsection{Vertical Positions Hypotheses:}

Vertical lines communicate high, strength, dignity and majesty. It can relay an impression of elegance and refinement (Cross, 2011).

Cross (2011) claims that 80 percent of customers will turn to the right upon centering a store. A Vertical retail display that is positioned at the end of an entry way aisle redirects the human tendency to move to the right after entering a retail store. The location of the item on Vertical shelf is very important, and has meaning from a customer's point of view, items on the lower shelves get less customer attention than on the upper, and may benefit less customer attention then on the upper.

According to Lefebvre (2007), Vertical merchandising allows retailers to group items in a way that helps customers see products better and reach them easier, that's because products arranged Vertically are at eye level and hand level at the same time.

Befebvre (2007) states that the products arranged close together in a Vertical arrangement also allow customers to see more of an assortment at one time, which could boost the purchases.

Consistent with Cross (2011), regarding customers impression about Vertically, Heler and Robinson (2004) found that customers believe that higher is better. This results were supported by the work of Schubert 
(2005), who studied the notion that the Vertical spatial positions are associated with power, products in higher physical positions are perceived to be more powerful.

Recent study conducted by Nelson and Simmons (2009) concluded that people shared beliefs that higher quality products are more likely to be in Northern position (versus southern). On this basis the researcher could propose the Verticality Hypothesis as follows:

H.1: There are significant differences related to the preferences of Vertical shelf space positions.

H.2: There are significant differences among customers, operations \& commercial department managers, and store managers with regard to the preference of the Vertical shelf space positions.

H.3: There are significant differences related to the perceived price of the products that are placed on the Vertical shelf space positions.

H.4: There are significant differences related to the perceived quality of the products that are placed on the Vertical shelf space positions.

H.5: There are significant differences among customers, operations \& commercial department managers and store managers with regard to perceived price of the products that are placed on the Vertical shelf space positions.

H.6: There are significant differences among customers operations \& commercial department managers, and store managers with regard to the perceived quality of the product that are placed on the Vertical shelf space positions.

\subsubsection{Horizontal Positions Hypotheses:}

Horizontal merchandising is frequently used for products display on one level like tables, and tiered retail fixtures.

Horizontal lines provide an easy going, restful quality is communicated when low, spreading lines are used in merchandising.

On the other hand, Horizontal merchandising restricts visibility and requires the shoppers to walk closer to see more. There are little prior researchers that examine the meaning associated with a left- right ordering. Valenzuela (2006) suggested that consumer associate positions that are to the right in a Horizontal shelf space array with having higher prices and quality.

The results of her study indicated that products in the center perceived to be the highest priced ones. Her study found that subjects did not place cheep and expressive brand differently along the Horizontal continuum. She concluded that people are unaware of the influence of Horizontal-order, of presentation on their judgments, and are unable to control it accordingly, the Horizontality hypothesis are: 
H.7: There are significant differences related to the preferences of the Horizontal shelf space positions.

H.8: There are significant difference among customers, operations \& commercial department managers and store managers with regard to the preferences of Horizontal shelf space positions.

H.9: There are significant differences related to the perceived price of the products that are placed on Horizontal shelf space positions.

H.10: There are significant differences among customers, operations \& commercial department managers and store managers with regard to the perceived price of the products that are placed on the Horizontal shelf space positions.

H.11: There are significant differences related to the perceived quality of the products that are placed on the Horizontal shelf space positions.

H.12: There are significant differences among customers, operations and commercial department managers and store managers with regard to the perceived quality of the products that are placed on the Horizontal shelf space positions.

\subsubsection{Placement choices by brand:}

H.13: There are significant differences among customers, operations \& commercial department managers, and store managers related to the placement choices by brand.

\subsection{Research Variables and measurement:}

Table 1 Represent research variables and measurement.

Table 1: Research variables and measurement.

\begin{tabular}{|c|c|c|}
\hline Measurement & Definition & Variables \\
\hline $\begin{array}{l}\text { The diagram at five levels, Vertically } \\
\text { Top } 1 \text {, Top } 2 \text {, center, Bottom } 1 \text { and } \\
\text { Bottom 2) and Horizontally (left } 1 \text {, left } \\
2 \text {, center, right } 1 \text { and right } 2 \text { ), in section } \\
\text { A in the questionnaire, as well as the } \\
\text { planogram of } 25 \text { celles in section B in } \\
\text { the Questionnaire in which the brand } \\
\text { are allocated. }\end{array}$ & $\begin{array}{l}\text { The position of the product on the } \\
\text { shelf regarding two placement } \\
\text { choices Horizontal (left to right) } \\
\text { and Vertical (top to Bottom), } \\
\text { (Benek, 2011) }\end{array}$ & $\begin{array}{l}\text { Independent Variable } \\
\text { - Shelf space position. }\end{array}$ \\
\hline $\begin{array}{l}\text { Item A.3.1 for Vertical and Horizontal } \\
\text { in section A. in the questionnaire, as } \\
\text { well as section B.3 in the questionnaire }\end{array}$ & $\begin{array}{l}\text { The degree to which customer } \\
\text { preference one brand position } \\
\text { over another (Gwin, 2009) }\end{array}$ & $\begin{array}{l}\text { Dependent variables: } \\
\text { - Shelf space position } \\
\text { preference }\end{array}$ \\
\hline $\begin{array}{l}\text { Item A.3.2 for Vertical and Horizontal } \\
\text { position in section A in the } \\
\text { questionnaire. }\end{array}$ & $\begin{array}{l}\text { Customer's judgment about a } \\
\text { brand's overall excellence or } \\
\text { superiority (zeithaml, 1988). }\end{array}$ & $\begin{array}{l}\text { - Perceived brand } \\
\text { quality. }\end{array}$ \\
\hline $\begin{array}{l}\text { Item A.3.3 for Vertical and Horizontal } \\
\text { positions in section A in the } \\
\text { questionnaire. }\end{array}$ & $\begin{array}{l}\text { The price as encoded by the } \\
\text { customer (zeithaml, 1988). }\end{array}$ & $\begin{array}{l}\text { - Perceived brand } \\
\text { price. }\end{array}$ \\
\hline
\end{tabular}




\subsection{Sampling:}

Sampling process includes population definitions, specifying sampling frame, sampling units and determining sample type and size. The following section represents this process.

\subsubsection{Managers' sample:}

The researcher collect data from all commercial department managers, (14 managers), operation managers and their assistants (11 managers), marketing managers (16 managers) and store managers and their assistants (51 managers).

\subsubsection{Customers' sample:}

Population consists of all COOP stores' customers from different districts, that covers all of Lebanon during the period from June 2010 to September 2011.

\subsubsection{Sampling Unit:}

The sampling unit was the COOP store at which the researcher met the customers and store managers and distributed questionnaires to collect data.

\subsubsection{Sample size:}

According to most marketing studies, when the community is large ( 100.000 or more) the size of the sample that can be reliable estimated at about 384 subjects under the following conditions:

- Confidence level is to be $95 \%$.

- The value of standard normal variable is 1.96 .

- Standard deviation is $30 \%$.

- Standard error is to be not more than $3 \%$.

Accordingly the equation is as follows $n=\left(S^{*}-\mathrm{Z}\right)^{2} / \mathrm{e}^{2}=$ $(1.960 \times 0.3)^{2} / 0.3^{2}=384$ subjects. Were:

$\mathrm{n}=$ number of subjects (sample size)

$\mathrm{s}=$ the value of standard normal variable.

$\mathrm{Z}=$ standard deviation.

$\mathrm{e}=$ standard error (Tull \& Wakins, 1993)

The sample type was a systematic traffic random sample because since there was no available sampling frame, since one questionnaire requires five minutes to be filled, the research select customer one, then number seven and so on.

\section{Data Collection:}

A self - administrated questionnaire was developed to callect the data, based on the results of the pilot study and the literature review (valenzula, 2009). 
The country manager for the united company for the Central market "Coop" sent the questionnaires to 37 store managers by mail, to collect the data.

The questionnaire is divided in two sections A and B. First section A was designed to measure the awareness of the Verticality and Horizontality schemas (shelf space schemas) for the following groups:

1-Customers who buy form the "Coop" stores

2-Operations \& commercial department managers who are responsible for developing planogram.

3-Store managers who supervise planograms integrity.

The purpose is to test whether the Horizontal and Vertical positions of the brand influence, the beliefs about its price and quality, and how these inferences affect product preferences.

A diagram at five levels was drawn labled (1,2,3,4 and 5) and laid out at two levels ( Horizontal and Vertical). Participants were asked to imagine that they visited one of the Coop stores, where they find only five different brand of apple Juice, and they do not have any information about them, the brands were allocated at shelves from 1-5 Vertically (top1, Top 2, center, Bottom, and Bottom2), and Horizontally (left1, left2, center, right1, and right2), they were asked to specify the cell from which they will choose and buy the products.

They were asked to allocate five different categories of prices ranged from ((1) 2000 L.L, (2) 20001-30999 L.L, (3) 4000-5999 L.L, (4)6000-7999 L.L, (5) 8000 L.L and more) for the five cells on the Vertical and Horizontal shelf space in addition, participants were asked to evaluate product quality and price for each shelf space position using a five- point liker scale, where 5 refers to agree strongly to disagree strongly.

Second section $\mathrm{B}$ is divided into three parts, B1, B2 and B3. Section B1 concentrates on placement choices by brand, an empty $5 \times 5$ (Rows x Columns) planogram was drawn which contains 25 cells, participants were asked to make decisions for arranging the brands with powder milk, described using eight descriptions: Price Leader, premium, promoted, popular, store, slow- moving, well- known, and new brand. The final design was a 5 (Vertical: Rows x 5 (Horizontal: columns) x 8 brands).

In section B2, participants were asked to chose of the 1 ideal, $2^{\text {nd }}$ best and the worst position from the 25 cells separately from the 25 cells separately from each of the eight brand descriptions. The aim was to test the preferences for Vertical position Top 1, cells (1, 2, 3, 4 and 5), Top2, cells $(6,7,8,9,10)$ Central, cells $(11,12 /, 13,14$ and 15), Bottom 1 (cells $(16,17,18,19$ and 20) and Bottom 2 cells $(21,22,23,24$ and 25), as well as the Horizontal positions, left 1 , cells, $(1,6,11,16$ and 21) left 2, cells 
(2,7,12,17 and 22), Central, cells (3, 8, 13, 18 and 23) Right 1 cells $(4,9,14,19$ and 24) and right 2 cells $(5,10,15,20$ and 25).

Participants were asked to also to allocate the eight brands to fill the 25 positions with at least one cell per brand, with multiple allocations possible.

In section B3 participants were asked to specify the references of each of the 25 cells using a five - point liker scale, 5 for agree strongly and 1 for disagree to measure face- validity, eight academic researchers at the faculty of commerce and business administration, Beirut Arab University, thirty of coop customers, 10 coop managers have evaluated the questionnaire. Based on their feedback and comment, several items, questions and plan grams were modified and simplified, Appendix B represents the questionnaire.

\section{Data Analysis and Hypotheses Test}

\subsection{Data Analysis for the brands choice and price estimation:}

Analysis of the Respondents choices concerning the brands and price categories of the brands for the two orientations is as follows.

\subsubsection{Vertical Orientation:}

Frequencies technique is used for the preferences of the Vertical shelf space positions. Table (2) show the results.

Table 2: The three groups of respondents choices by brand for the Vertical shelf space positions

\begin{tabular}{|c|c|c|c|}
\hline $\begin{array}{c}\text { Store Managers } \\
\mathbf{N = 5 1}\end{array}$ & $\begin{array}{c}\text { Customers } \\
\mathbf{N = 3 8 4}\end{array}$ & $\begin{array}{c}\text { Operations \& Commercial } \\
\text { department manager } \\
\mathbf{N = 4 1}\end{array}$ & Respondents \\
\hline $30(58 \%)$ & $180(47 \%)$ & $30(75 \%)$ & Top 1 \\
\hline $28(55 \%)$ & $170(44 \%)$ & $25(62 \%)$ & Top 2 \\
\hline $35(69 \%)$ & $160(42 \%)$ & $12(30 \%)$ & Central \\
\hline $10(28 \%)$ & $100(26 \%)$ & $10(25 \%)$ & Bottom 1 \\
\hline $7(14 \%)$ & $20(0.53 \%)$ & $8(20 \%)$ & \\
\hline
\end{tabular}

The results indicate that operations \& commercial department managers, and customers prefer Top positions to chose the brand, over Central and Bottom positions, but store managers, prefer Central position over Top and Bottom positions.

The results also indicate that price estimates decreased from Top to Bottom for operations \& commercial department managers and customers, but store managers estimate the higher price for center position. Table (3) shows the frequencies as percentage of respondents who estimate each price category for the different shelf space positions. 
Table 3: The three groups of respondents price estimation for the Vertical shelf space positions

\begin{tabular}{|c|c|c|c|c|c|c|c|c|c|}
\hline \multicolumn{2}{|c|}{$\begin{array}{c}\text { Store managers } \\
\text { N=51 }\end{array}$} & \multicolumn{3}{c|}{$\begin{array}{c}\text { Customers } \\
\text { N= 384 }\end{array}$} & \multicolumn{2}{c|}{$\begin{array}{c}\text { Operations \& } \\
\text { Commercial } \\
\text { department managers } \\
\text { N= 41 }\end{array}$} & Positions \\
\hline Percentage & Frequencies & $\begin{array}{c}\text { Price } \\
\text { category }\end{array}$ & Percentage & Frequencies & $\begin{array}{c}\text { Price } \\
\text { category }\end{array}$ & $\begin{array}{c}\text { percentag } \\
\text { e }\end{array}$ & Frequencies & $\begin{array}{c}\text { Price } \\
\text { category }\end{array}$ & \\
\hline $88 \%$ & 45 & 5 & $70 \%$ & 300 & 5 & $85 \%$ & 35 & 5 & Top 1 \\
\hline $78 \%$ & 40 & 4 & $83 \%$ & 320 & 4 & $92.6 \%$ & 38 & 4 & Top 2 \\
\hline $88 \%$ & 45 & 3 & $72 \%$ & 280 & 3 & $68 \%$ & 28 & 4 & Center \\
\hline $68 \%$ & 35 & 2 & $65 \%$ & 250 & 2 & $78 \%$ & 32 & 3 & Bottom 1 \\
\hline $82 \%$ & 42 & 1 & $75.5 \%$ & 240 & 1 & $92.6 \%$ & 38 & 1 & Bottom 2 \\
\hline
\end{tabular}

\subsubsection{Horizontal Orientations:}

The results indicate that the three groups of respondents prefer right positions over left. And then estimate higher prices for the brands on right positions over left positions. Table (4) and (5) show the results of the frequencies test.

Table 4: The three groups of respondents choice by brand for Horizontal Shelf space positions

\begin{tabular}{|c|c|c|c|}
\hline Store Managers & Customers & $\begin{array}{c}\text { Operations \& Commercial } \\
\text { department manager }\end{array}$ & Positions \\
\hline $40(78 \%)$ & $200(52 \%)$ & $32(78 \%)$ & Right 1 \\
\hline $39(76.5 \%)$ & $195(51 \%)$ & $30(73 \%)$ & Right 2 \\
\hline $38(74.5 \%)$ & $180(47 \%)$ & $30(73 \%)$ & Center \\
\hline $22(43 \%)$ & $110(29 \%)$ & $17(41 \%)$ & Left 1 \\
\hline $10(19 \%)$ & $95(25 \%)$ & $25(62.3 \%)$ & Left 2 \\
\hline
\end{tabular}

Table 5: The three groups of respondents choice by brand (Horizontal orientation)

\begin{tabular}{|c|c|c|c|c|c|c|c|c|c|}
\hline \multicolumn{4}{|c|}{ Store managers } & \multicolumn{3}{|c|}{ Customers } & \multicolumn{2}{c|}{$\begin{array}{c}\text { Operations \& Commercial } \\
\text { department managers }\end{array}$} & Respondents \\
Positions \\
\hline Percentage & Frequencies & $\begin{array}{c}\text { Price } \\
\text { category }\end{array}$ & Percentage & Frequencies & $\begin{array}{c}\text { Price } \\
\text { category }\end{array}$ & percentage & Frequencies & $\begin{array}{c}\text { Price } \\
\text { category }\end{array}$ \\
\hline $78 \%$ & 40 & 5 & $83 \%$ & 320 & 5 & $85 \%$ & 35 & 5 & Right 1 \\
\hline $68 \%$ & 35 & 4 & $78 \%$ & 300 & 5 & $80.4 \%$ & 33 & 4 & Right 2 \\
\hline $78 \%$ & 40 & 4 & $62.5 \%$ & 240 & 3 & $68 \%$ & 28 & 4 & Center \\
\hline $88 \%$ & 45 & 3 & $78 \%$ & 300 & 3 & $85 \%$ & 35 & 3 & Left 1 \\
\hline $94 \%$ & 48 & 1 & $80.7 \%$ & 310 & 2 & $97 \%$ & 40 & 2 & Left 2 \\
\hline
\end{tabular}




\subsection{Hypotheses Test:}

\section{H.1}

ANOVA test is used to test the differences among the Vertical shelf space positions' preferences for the three groups of respondents. The results of the ANOVA test indicate that the three groups of respondents prefer Top positions, the preferences decreased from Top to Bottom. For customers group means are $=(\operatorname{top} 1=4.4635 ;$ Top $2=4.2786$; center $=$ 3.0313; Bottom 1= 1.6719 and Bottom 2=1.6094, F-value $=2642.58$ and $\mathrm{P}-$ Value $=0.000)$.

For operations \& commercial department managers group means are $=($ top $1=4.8787 ;$ Top $2=4.3171 ;$ center $=3.0244 ;$ Bottom $1=1.7317$ and Bottom $2=1.5366$, F- Value $=372.66$ and $\mathrm{P}-$ Value $=0.000$ ).

For store managers means are $=($ top $1=4.4902$, Top $2=4.3137$, center $=2.9216$; Bottom $1=1.6863$ and Bottom $2=1.7059$, F-Value $=$ 459.59 and $\mathrm{P}-$ Value $=0.000$ ).

Thus H. 1 is supported for the three groups of respondents. Tables (1-3) in appendix C show the results of the ANOVA test for H.1.

\section{H.2}

ANOVA test is used to measure the differences among the three groups of respondents, regarding the preferences of the Vertical shelf space positions.

The results of the ANOVA tests indicate that there are no significant differences among the three groups of respondent with regard to the preferences of Top 1 on the Vertical shelf space positions, (the means are $=4.4635 ; 4.4878$ and 4.4902, F- Values $=0.09$ and $\mathrm{P}-$ Value $=$ 0.915 ), as well as for Top 2 (means are $=4.2786$; 4.3171 and 4.3137, FValue $=0.09$ and $\mathrm{P}-$ Value $=0.8310$ )

The results also indicate that there are no significant differences among the three groups with regard to the Central positions, means are= (3.0313; 3.0244 and 2.9216, F-Value $=1.49$ and P-Value= 0.227). as well as for Bottom I, means are $=(1.6719 ; 1.7317$ and 1.6867. $\mathrm{F}-$ Value $=0.26$ and $\mathrm{P}$-Value $=0.7680)$. For Bottom 2 means are $=(1649,1.5365$ and 1.7059, F-Value $=1.36$ and $\mathrm{P}-$ Value $=0.273)$. Thus H.2 is not supported for the three groups of respondents. Table (4) in Appendix $\mathrm{C}$ shows the results of the ANOVA test for H. 2.

\section{H.3}

ANOVA test is used to measure the differences of the perceived price of the products that are placed on Vertical shelf space positions. The results indicate that there are significant differences of the perceived prices for the products that are placed on the Vertical shelf space positions. The means reducing from Top to Bottom. For customers group 
means are $=($ top $1=4.3828 ;$ Top $2=2.2969 ;$ center $=2.9479 ;$ Bottom $1=$ 1.6589 and Bottom $2=1.6406, \mathrm{~F}-$ Value $=277.58$ and $\mathrm{P}-$ Value $=0.000$ ). For operations \& commercial department managers, means are $=($ top $1=$ 4.4878; Top 2= 4.5366; center $=2.9024$; Bottom $1=1.5610$ and Bottom $2=1.6585, \mathrm{~F}-$ Value $=399.46$ and $\mathrm{P}-$ Value $=0.000)$.

For store managers, means are $=(\operatorname{top} 1=4.4902$, Top $2=4.3137$, center $=2.9216$, Bottom $=1.6863$, Bottom $2=1.7059$. F-Value $=459.59$ and P-Value $=0.000$ ). Thus H.3 is supported for the three groups of respondents. Tables (5-7) in the appendix C Show the results of the ANOVA Test for H. 3.

\section{H.4}

ANOVA test is used to test the differences among the three groups of respondents with regard to the perceived price of the products that are placed on different Vertical shelf space positions.

The results of the ANOVA test indicate that there are no significant difference among the three groups of respondents with this regard. For Top 1 means are $=(4.3828 ; 4.8178$ and $4.4902, \mathrm{~F}-$ Value $=1.51$ and $\mathrm{P}-$ Value $=0.223)$, for Top 2 means are $=(4.2969 ; 4.5360$ and 4.3139 , FValue $=3.67$ and $\mathrm{P}-$ Value $=0.026)$, for Vertical center position means are $=(2.9479 ; 2.9024$ and 2.9216. $\mathrm{F}-$ Value $=0.27$ and $\mathrm{P}-$ Value $=0.762)$.

For Bottom 1 means are $=(1.6589,1.516$ and 1.6863. F-Value $=$ 0.90 and P-Value $=0.407)$. For Bottom 2 Means are $=(1.6406,1.6585$ and 1.7059, F-Value $=0.42$ and P-Value= 0.657). Thus H. 4 is not supported. Table (8) in appendix $\mathrm{C}$ shows the results of the ANOVA test for H. 4.

\section{H.5}

ANOVA test is used to measure the differences on the perceived quality of the products that are placed on the different Vertical shelf space positions.

The results of the ANOVA test indicate that there are significant differences on the perceived quality of the products that are placed on different Vertical shelf space positions for the three groups of respondents.

For customers group, means are $=(\operatorname{top} 1=3.9683$; Top $2=3.9505$, center $=4.3880$, Bottom $1=2.0365$ and Bottom $2=2.0391$, F-Value $=$ 1071.2 and P-Value $=0.000)$. For the operations \& commercial department managers group, means are $=($ top $1=3.9756$; Top $2=4.0244$, center position $=4.3415$; Bottom $1=1.9756$ and Bottom $2=2.0752$, $\mathrm{F}-$ Value $=120.000$ and $\mathrm{p}$-value $=0.000)$. Fore store managers, means are $=$ (top 1=4.4092; Top 2= 4.3137, center $=2.5216$, Bottom $1=1.6863$ and Bottom $2=1.7059$, F- Value $=459.59$ and $\mathrm{P}-$ Value $=0.000$ ). Thus H. 5 is 
supported for the three groups of respondents. Tables (9-11) in appendix $\mathrm{C}$ show the results of the ANOVA test for H. 5.

\section{H.6}

ANOVA tests is used to test the differences among customers, operations \& Commercial department managers and store managers' perception of the quality the products that are placed on different Vertical shelf space positions.

The results of the ANOVA test indicate that there are significant differences among the three groups of respondents related to the perceived quality of the products that are placed on different Vertical shelf space positions. For Top 1, means are $=(3.9580,3.9756$ and 4.4902, $\mathrm{F}-$ Value $=12.47$ and P- Value $=0.000)$. For Top 2 means are $=(3.9505$, 4.0244 and 4.3137). F-Value $=5.65$ and $\mathrm{P}$-value $=0.004$ ).

For Central Vertical position, mean are $=(4.3880,4.3415$ and 2.9216, F-Value $=198.43$ and P-Value $=0.000)$. For Bottom1, means are $=(2.0365 ; 1.9756$ and 1.6863, F-value $=6.08$ and $\mathrm{P}$-value $=0.002)$. for Bottom 2 means are $=(2.0391 ; 2.0732$ and $1.7059, \mathrm{~F}$-value $=5.75$ and $\mathrm{P}-$ value $=0.003$ ), Thus H. 6 is supported. Table (12) in Appendix C shows the results of the ANOVA Test for H. 6 .

\section{H.7}

ANOVA test is used to test the differences among the Horizontal shelf space positions' preferences for the three groups of respondents.

The results of the ANOVA test indicate that the three groups of respondents prefer right positions, the preferences means decreased from right to left. For customers group means are $=$ (right $1=4.4375$; right $2=$ 4.3411, Central $=2.8964$; left $1=1.6979$ and left $2=1.6563$, F-value $=$ 3233.07 and P-value $=0.000$ ).

For operations \& commercial department managers, means are $=$ (right $1=4.4634$ ); right $2=4.4390$; Central $=2.9268$; Left $1=1.5854$ and left $2=1.6341, \mathrm{~F}$-value $=389.60$ and $\mathrm{p}$-value $=0.000$ ).

For store managers, means are $=($ right $1=4.5294$; right $2=4.3922$; Central $=2.8235$; left $1=1.6078$, left $2=1.6471$, F-value $=443.28$ and $\mathrm{P}$-value $=0.000$ ). Thus H.7 is supported.

Tables (13-15) in appendix $\mathrm{C}$ show the results of the ANOVA test for H.7.

\section{H.8}

ANOVA test is used to test the differences among the three groups of respondents regarding the preferences of the Horizontal shelf space locations. 
The results of the ANOVA test indicate that there are no significant differences among the three groups of respondents, with regard to the preferences of the Horizontal shelf space positions.

For right 1 , means are $=(4.4386 ; 4.4634$ and 4.5294 . F-value $=0.74$ and P-value $=0.479)$. For right 2 , means are $=(4.3394,4.4390$ and 4.3922, $\mathrm{F}-$ Value $=0.92$ and $\mathrm{P}$-value $=0.400)$. For Central position, means are $=$ $(2.8982,2.9268$ and 2.8239, F-Value $=1.21$ and P-Value $=0.300)$. For left 1 , means are $=(1.6971 ; 1.5854$ and $1.6078, \mathrm{~F}$-value $=1.53$ and $\mathrm{P}$-value $=$ $0.219)$. For left 2 , Means are $=(1.6580 ; 1.6341$ and 1.6471, F-Value $=0.05$ and $\mathrm{P}$-value $=0.948$ ).

Thus H.8 is not supported. Table (16) in appendix C shows the results of the ANOVA test for H. 8 .

\section{H.9}

ANOVA test is used to test the differences on the perceived price of the products that are placed on different Horizontal shelf space positions.

The results of the ANOVA test indicate that there are significant differences on the perceived price of the products that are placed on the different positions on the Horizontal shelf space. For customers group, means are $=$ (right $1=4.3464$; right $2=4.4010$; Central $=2.9089$; left $1=$ 1.7260 and Left $2=1.7500$, F-value $=2544.4$ and $p$ - value $=0.000$ ).

The means reducing from right to left. Thus $\mathrm{H} .9$ was supported for customers group.

For operations \& commercial department managers, means are $=$ (right $1=4$; right $2=4.122$; center $=4.4878$; left $1=2$ and left $2=1.9512$. $\mathrm{F}$-value $=137.78$ and $\mathrm{P}$-value $=0.000$ ).

The highest mean is for Central position. Thus H. 9 is supported for operations \& commercial department managers. For store managers, the means are reducing from right to left, means are $=($ right $1=4.5294$; right $2=4.3922$, center $=2.9216$; left $1=1.7255$ and left $2=1.7451$, Fvalue $=311.39$ and $\mathrm{P}-$ Value $=0.000$ ). Thus H. 9 is supported for the three groups of respondents. Tables (17-20) in appendix $\mathrm{C}$ show the results of the ANOVA tests for H.9.

\section{H.10}

ANOVA test is used to test the differences among the three groups of respondents with regard to perceived price of the products that are placed on different Horizontal shelf space positions.

The results indicate that there are significant differences among the three groups of respondents with regards to right 1 and center positions.

For right 1 means are $=(4.3464 ; 4 ; 4$ and $4.5294 ; \mathrm{F}$-value $=11.4$ and $\mathrm{P}$-value $=0.000)$. For center position means are $=(2.9080 ; 4.4878$ and 
2.9216; F- value $=251,33$ and $P$-value $=0.000$ ). but no significant differences are found for right 2 , left 1 and left 2 . For right 2 means are= (4.4010, 4.1220 and 4.3922, F-value $=5.01$ and $\mathrm{P}$-value $=0.007)$, for left 1 , means are $=(1.7266 ; 2$ and $1.7255, F-$ value $=4.19$ and $\mathrm{P}$-value $=0.16)$ for left 2 , means are $=(1.7500,1.9512$ and $1.7451, \mathrm{~F}$-value $=2.38$ and $\mathrm{P}-$ value $=0.093$ ) .

Thus H.10 is supported for right 1 and center positions, and not supported for right 2, left 1 and left 2 . Table (20) in appendix C shows the results of the ANOVA test for $\mathrm{H} .10$.

\section{H.11}

ANOVA test is used to measure the differences on the perceived quality of the products that are placed on the different Horizontal shelf space positions.

The results of the ANOVA test indicate that there are significant differences on the perceived quality of the products that are placed on different Horizontal shelf space positions.

For customers group, the results of the ANOVA indicate that there are significant differences related to the quality of the products that are placed on the Horizontal shelf space positions.

The center of the array has the highest mean are $=(4.3854$ followed by right 2 ; mean $=3.9661$, right 1 , mean $=3.9427$, left 2 , mean are $=$ 2.0599 and left 1 mean= 2.0147, F-value $=1006.7$ and $\mathrm{P}$-value $=0.000$ ).

Thus H. 11 is supported for customer group. As for operations \& commercial department managers, the center of the array has the highest mean are $=(4.61634$, followed by right 1 , mean are $=3.9024$, right 2 mean are $=3.8537$, left 1 and left 2 , mean $=2$, F- value $=118.85$ and $\mathrm{P}-$ Value $=$ $0.000)$.

Thus H. 11 is supported for operations \& commercial department managers.

For store managers right 1 has the highest mean $=(4.5294$, right 2 mean are $=4.3922$, center, mean $=2.7647$, left 2 , mean are $=1.8235$ and left 2 , mean are $=1.8639$. F- value $=219.53$ and $\mathrm{P}-$ Value $=0.000$ ).

The means are descending from right to left. Thus H. 11 is supported for the three groups of respondents. Tables (21-23) in appendix $\mathrm{C}$ show the results of the ANOVA test for H. 11 .

\section{H.12}

ANOVA test is used to test the differences among customers, operations \& commercial department managers and store managers with regard to the perceived quality of the products that are placed on different positions on the Horizontal shelf space. 
The results of the ANOVA test indicate that there are significant differences among the three groups of respondents with regard to the perceived quality of the products that are placed on the different Horizontal shelf space for right 1, right 2 and Central positions, but no significant differences are found with regards to left 1 and left 2 positions. For right 1 means are $=(3.9427 ; 3.8537$ and 4.5294 , F-Value $=$ 14.91 and P-Value $=0.000)$. For right 2 Means are $=(3.9661 ; 3.9024$ and 4.3922, F-Value $=8.45$ and $\mathrm{P}$-value $=0.000$ ). For Central position, means are $=(4.3854,4.4634$ and 2.7647, $\mathrm{F}$-value $=180.66$ and $\mathrm{P}$-value $=0.000)$.

Fore left 1 , means are $=(2.0417,2.000$ and 1.8039, F-value $=2.29$ and P-Value $=0.076$ ).

For left 2, means are $=(2.0599 ; 2000$ and $1.8235, \mathrm{~F}-$ Value $=2.49$ and

P-Value $=0.084$ ). Thus H.12 is supported for right 1, right 2 and Central Positions, but was not supported for the left 1 and left 2 positions.

Table (24) in Appendix C shows the results of the ANOVA test for H. 12.

\section{Placement Choices by Brands: H.13}

H. 13 is tested using two techniques, the first is the placement choices by brand, choices of Ideal, $2^{\text {nd }}$ best and worst position from the 25 cells separately, for each of the eight brands descriptions, this techniques is used for the three groups of respondents.

The second technique is the measurement of rows and columns, preferences, for each of the five rows and five columns, using a-fivepoint Likert type scale. This technique is applied for the three groups of respondents.

The one-way analysis of variance is used to measure the differences on the respondents' preferences for rows and columns.

\section{Placement choices for ideal, $2^{\text {nd }}$ best and worst positions.}

Table (25) in Appendix C shows the placement choices by brand for the three groups of respondents as a percentages of the frequencies of these choices. For customers group, the results indicate the center of the array, (Cells 8, 13, and 18) was chosen as the ideal positions for four brands $($ Premium $=19.8 \%$; Popular $=14.8 \%$; new $=20.6 \%$ and Slowmoving $=15.6 \%)$. The extreme - left positions, cells $(5,10,15$, and 25) were chosen as the $2^{\text {nd }}$ best positions for four brands, (Cheapest $=14.3 \%$; Well-known $=14.6 \%$; New $18.2 \%$ and slow - moving $=16.4 \%)$.

The second right positions (cells 17, 22) were chosen as the worst position for two brands, premium 12\% and popular, 9.9\%. (Customers Questionnaire was designed in Arabic Language). 
For store managers, the center of the array cells, $(8,13,23)$, was chosen as the ideal position for six brands (cheapest $=25.5 \%$; premium $=$ $25.5 \%$; popular $=25.5 \%$; promoted $=25.5 \%$; well- known $=27.5 \%$ and slow- moving $=25.5 \%$ ). The second Bottom position, (Cells 22, 23, and 25 ) were chosen as the $2^{\text {nd }}$ best positions for four brands, (store $=19.64 \%$; well- known $=16.7 \%$; new $=31.4 \%$ and slow- moving $=29.4 \%$ ).

The second left positions, (cells, 2, 12, and 22) were chosen as the worst positions for four brands, $($ premium $=27.5 \%$; promoted $=15.7 \%$, well- know $=19.6 \%$ and new $=21.6 \%$ ).

For operations \& commercial department managers, similar to customers and store managers groups, the center of the array Vertically (cells, 8, 12, and 23) was chosen as the ideal positions for five brands,. (popular $=26 \%$; slow - moving $=22 \%$; premium $=31 \%$; store $=31 \%$ and well- known $=39 \%$ ).

The center positions Horizontally, (cells 11, 13, 14, and 15) were chosen as the second best positions for five brands (store $=24.4 \%$, cheapest $=31 \%$; well- known $=39 \%$; premium $=24 \%$ and slow - moving $=$ $26 \%)$.

The second Bottom positions, (cells 21, 22, 24, and 25), were chosen as the worst positions for five brands, (cheapest $=24 \%$; premium $=$ $29 \%$; popular $=19 \%$; promoted $=41 \%$ and slow- moving $=36 \%$ ). Thus. $\mathrm{H}$. 13 is supported.

Table (25) in appendix $\mathrm{C}$ shows the placement choices by brands among the 25 cells, and table (26) shows a comparison among customers, store managers and operations \& commercial department managers with regard to the Ideal, $2^{\text {nd }}$ best and the worst position for each brand.

\section{Rows and Columns preferences by brand.}

One way analysis of variance is used to measure the differences among the three groups of respondents regarding the preferences of rows and columns, for the eight brands and two orientations, Horizontal orientation left (column 1 and 2), Central (column 3) and right 1 (column 5), and right 2 (column 4), and Vertical orientation Top first two rows (1, 2), Central the third row and Bottom, the fourth and fifth rows as follow.

\section{Customers group:}

\section{Horizontal orientation.}

The results of the ANOVA test indicate that the left 1 position was the first preferred position for the well-known brand, (mean=3.5634, $\mathrm{F}=$ 39.33 and $\mathrm{p}$ - value $=0.000$ ), the second choice for store brand, (mean= $(3.2721, \mathrm{~F}-$ value $=24.60$ and $\mathrm{p}$-value $=0.000)$, left 2 was chosen as the first preferred position for promoted brand, mean $=(3.5156, \mathrm{~F}-$ Value $=$ 
344.16 and $p$-value $=0.000)$, and store brand, mean $=(3.3637, \mathrm{~F}-$ Value $=$ 24.60 and $\mathrm{P}$-value $=0.000$ ), and the second preferred position, for the well-known brand, $($ mean $=3.2951, \mathrm{~F}-$ Value $=39.33$ and $\mathrm{p}$ - value $=0.000)$ and New brand, (mean $=3.6983$, F-value $=419.33$ and $p$-value $=0.000)$.

The Horizontal center of the array was chosen as the first preferred position for premium, popular, new and slow moving, means $=(3.2490$, $3.8214,3.7177$ and 4.8609 , p- value $=0.000$ ).

The first right positions was chosen as the first preferred position for the cheapest, $($ mean are $=4.762, \mathrm{~F}-$ value $=5821$ and $\mathrm{p}$ - value $=0.000)$ while the second right position was chosen as the second preferred choice for the premium and popular brands, (means are $=3.2234,3.7057$, Pvalue $=0.000$ ). These results indicate that the Horizontal center of the array was chosen as the first preferred position for four brands.

Thus H.13 is supported for customers group with regard to the Horizontal orientation. Table (27) in appendix $C$ shows the results of the ANOVA test for H. 13.

\section{Vertical orientation:}

The results of the ANOVA test indicate that the Top 1 position was chosen as the first preferred position for the well- known brand, (mean= 3.6809 , $\mathrm{p}$ - value $=0.000$ ), the second preferred position for popular and Slow - Moving brands, (means $=3.5036$ and 3.6849, $\mathrm{p}$ - value $=0.000$ ).

Top 2 was chosen as the first preferred positions for premium, promoted and new brands. (means= 3.7321, 3.7552 and 3.8906 and $\mathrm{P}$ - value $=0.000$ ), and the second preferred position for store brand, $($ mean $=3.396$ and $p-$ value $=0.000)$.

The Vertical center of the array was chosen as the first preferred position for the cheapest, popular and store brands, (means $=3.882$, 3.7240; 3.527, $\mathrm{p}$ - value $=0.000$ ).

The first Bottom was chosen as the second preferred position for the well- known and new brands, (means $=3.4276,3.1479$, P-value $=$ $0.000)$.

The second Bottom was chosen as the most preferred position for Slow - Moving brand, $($ mean $=3.773$, P-value $=0.000)$.

Thus the second Top and Vertical Central positions were the most preferred positions. Table (28) in appendix $\mathrm{C}$ shows these results from customer's point of view. Thus H. 13 is supported for customers group, with regard to Vertical orientation.

\section{Store managers group:}

\section{Horizontal Orientation:}

The results of the ANOVA test indicate that the first left position was chosen as the first preferred position for store brand, (mean=3.3640 
and $\mathrm{P}$-value $=0.000$, and the second preferred positions for the wellknown and new brands, $($ mean $=3.2078 ; 3.3640$ and $\mathrm{P}-$ Value $=0.000)$. The second left position was chosen as the first choice for new brand $($ mean $=3.588, \mathrm{P}$-value $=0.000)$ and the second preferred position for promoted brand, $($ mean $=3.5120, \mathrm{~F}-\mathrm{value}=53.63$ and $\mathrm{p}$-value $=0.000)$.

The center of the array was chosen as the first preferred position for premium, popular, promoted, well-known and slow-moving brands $($ means $=3.959,3.88,3.956,3.775$ and 3.8680, $\mathrm{p}$-value $=0.000)$, and the second choice for store brand, $($ mean $=3.0120$ and $\mathrm{p}$-value $=0.000$ ).

The second right position was chosen as the second preferred positions for the cheapest, and premium brands, (means $=3.1240,3.6824$, p-value $=0.000$ ).

The first right position was chosen as the first preferred choice for the cheapest brand, $($ mean $=4.6960$ and $p$-value $=0.000)$, and the second positions for the popular and slow moving brands, (means $=3.7240$, 3.0280 and p-value $=0.000$ ). Table (29) in Appendix $\mathrm{C}$ shows the results of the ANOVA Test. Thus H.13 is supported for store managers group with regard to Horizontal orientation.

\section{Vertical orientation:}

According to the results of the ANOVA test Top1 was chosen as the first preferred position for new brand, $($ mean $=3.7765$, $\mathrm{p}$-value $=$ $0.000)$, Top 2 was chosen as the first preferred position for promoted brand. $($ mean $=3.7640$ and Slow - Moving, mean $=3.9490, \mathrm{P}$-value $=$ $0.000)$.

The Vertical Central position was chosen as the first preferred choice for premium, popular and well- known brands, (means $=4.1918$, 4.100 and 3.7020, P-value $=0.000$ ), and the second preferred choice for the cheapest and promoted brands, (means $=3.928,3.1259$ and Pvalue $=0.000$ ). The first Bottom is the first preferred place for store brand, $($ Mean $=2.876$ and $\mathrm{P}$-value $=0.000)$.

The first Bottom was chosen as the first preferred position for the cheapest brand, $($ mean $=2.9920$ ) and the second preferred position for store, well-known, new and slow-moving brands, (means $=3.800 ; 3.0627$, 3.666 and 3.1412 and $\mathrm{P}-$ value $=0.000$ ).

Table (30) in the appendix $\mathrm{C}$ shows the results of the ANOVA Test. Thus H. 13 is supported for store managers group with regard to the Vertical orientation.

\section{Operations \& Commercial department managers group:} Horizontal orientation:

According to the ANOVA results, left 1 is the first preferred place for the new brand, (mean $=4.8200$ and $\mathrm{P}$-value $=0.000$ ), left 2 is the 
second preferred positions for store, well-known and Slow - Moving brands, (means $=4.4590,4.6700,4.600$ and $\mathrm{P}$-value $=0.000$ ). The Central of the array is the first preferred positions for the cheapest, store and wellknown brands, $($ means $=4.5900 ; 4.8300 ; 4.8600$ and $4.775 \mathrm{P}$-value $=$ 0.000 ), the second right position is the first preferred position for premium, popular and promoted brands, (means $=4.88,4.7650$ and 4.750 and P-value $=0.000)$. Table (31) in appendix $\mathrm{C}$ shows the results of the ANOVA Test. Thus H. 13 is supported for operations \& commercial department managers group with regard to Horizontal orientations.

\section{Vertical orientation:}

The results of the ANOVA Test indicate that Bottom1 is the first preferred positions for seven brands, cheapest, premium, popular, promoted, store, well-known and Slow - moving, (means $=3.4600$; $3.8800 ; 3.7139 ; 3.6700 ; 3.6700 ; 3.7750$ and 3.8005$)$, but the results are not significant for the popular, $(\mathrm{p}$-value $=0.509$, promoted, $\mathrm{p}$-value $=$ 0.874 and store brand, $\mathrm{p}$-value $=0.761)$.

Central position was the first preferred position for the new brand, (mean $=3.990$ and $\mathrm{P}$-value $=0.000$ ), the second Bottom position was chosen as the second preferred position for premium, (mean $=3.7019$, $\mathrm{p}$ value $=0.000$ and slow-moving, mean $=3.7487$ and $\mathrm{p}$-value $=0.000$ ) . Thus H.13 is supported for operations \& commercial department managers group with regard to Vertical orientation. Table (32) in Appendix C shows the results of the ANOVA test for H.13.

Table (6) summarize the results of the ANOVA test related to the preferred, shelf space positions for the eight brands, for the three groups of respondents.

Table 6: ANOVA test results for the preference of shelf Space positions for the three groups of respondents

\begin{tabular}{|c|l|c|l|c|l|l|}
\hline \multicolumn{7}{|c|}{ The most preferred shelf space positions } \\
\hline $\begin{array}{c}\text { Operations \& commercial } \\
\text { department managers }\end{array}$ & \multicolumn{2}{|c|}{ Store managers } & \multicolumn{2}{|c|}{ Customers } & Brands \\
\hline $\begin{array}{c}\text { Cell } \\
\text { number }\end{array}$ & Position & $\begin{array}{c}\text { Cell } \\
\text { number }\end{array}$ & \multicolumn{1}{|c|}{ Position } & $\begin{array}{c}\text { Cell } \\
\text { number }\end{array}$ & Position & \\
\hline 18 & Bottom1, Central & 24 & $\begin{array}{l}\text { Right2, } \\
\text { Bottom2 }\end{array}$ & 3 & Right2, Central & Cheapest \\
\hline 19 & Bottom1, right1 & 13 & Central, Central & 8 & Top2, Central & Premium \\
\hline 19 & Bottom1, right1 & 13 & Central, Central & 13 & Central, Central & Popular \\
\hline 8 & Top2, Central & 8 & Top2, Central & 7 & Top2, left2 & Promoted \\
\hline 18 & Bottom1, Central & 16 & Bottom1, left1 & 12 & Left2, Central & Store \\
\hline 18 & Bottom1. Central & 13 & Central, Central & 1 & Top1, left2 & Well-known \\
\hline 11 & Left1, Central & 2 & Top1, left 2 & 8 & Top2, Central & New \\
\hline 18 & Bottom1, Central & 8 & Top2, Central & 3 & Top1, Central & $\begin{array}{l}\text { Slow- } \\
\text { moving }\end{array}$ \\
\hline
\end{tabular}

ANOVA test is used to test the differences among the three groups of respondents related to preferred positions by brand. 
For Horizontal shelf space positions, customers have the highest mean for left1 and 2, for the cheapest brand, (means are 3.400 and 3.956, F-value $=284.69$ and $\mathrm{p}$-value $=0.000$ ), premium brand, (means are 3.1300 and 3.4964, F-value $=106.30$ and $p$-value $=0.000)$ and popular brand, (means are 3.8762 and 3.3594, F-value $=210$, and $p$-value $=0.00$ ), while store managers have the highest means for the promoted brand, regarding left1 and 2 position, (means are $=3.1280$ and $3.5120, \mathrm{~F}-\mathrm{value}=$ 118.7 and $\mathrm{p}$-value $=0.000)$. Operations \& commercial department managers have the highest means for left1 and 2, regarding new Brand, (means $=4.8200$ and 4.155, F-value $=219.19$ and $p$-value $=0.000)$ as well as the well-known, brand, (means $=4.6050$ and $4.7600, \mathrm{~F}$-value $=76.22$ and $\mathrm{p}$-value $=0.000$ ). Table (33) in the appendix $\mathrm{C}$ shows the results of the ANOVA test for H. 13. Thus H. 13 was supported.

For Horizontal Central positions, operations \& commercial department managers have the highest means for the cheapest, premium, popular, promoted, store, well-known brands. (means are $=$ (4.3900, $\mathrm{F}$-value $=580.95 ; 4.700, \mathrm{~F}$-value $=629.22 ; 4.7100, \mathrm{~F}$-value $=125.06 ;$ $3.556, \mathrm{~F}-$ value $=76.63 ; 4.83, \mathrm{~F}-$ value $=194 ; 4.8600, \mathrm{~F}-\mathrm{value}=78.61$, and $\mathrm{p}$-value $=0.000$ ).

Customers have the highest mean for the new brand (mean= 3.7177, F-value $=19.400)$ and slow-moving $($ mean $=4.866$, F-value $=$ 479.46 and $p$-value $=0.000)$. Thus $\mathrm{H}$. 13 is supported for the Central positions. Table (34) in appendix $\mathrm{C}$ shows the results of the ANOVA Test for H. 13

For the Right positions, right 1 and 2, operations \& commercial department managers have the highest means for six brands, popular, promoted, store, well-known, new and slow-moving, $($ means $=$ right $2=$ $3.6250, \mathrm{~F}$-value $=13.44 ;$ right $1=3.575, \mathrm{~F}$-value $=28.92 ;$ right $1=3.6856$, $\mathrm{F}$ - value 106.91 ; right $2=3.560, \mathrm{~F}$-value $=106.91$; right $1=3.6609$, $\mathrm{F}-$ value $=90.5$; right $1=3.947, \mathrm{~F}-$ value $=244.13$ and $\mathrm{P}-$ value $=0.000$, right $2=3.889, \mathrm{~F}$-value $=244.13$ and right $1=3.684, \mathrm{~F}$-value $=71.43$ and $\mathrm{P}$-value $=0.000$ ).

Customers have the highest mean for premium and popular, (Means $=$ Right $2=3.7321$, F-value $=85$, Right $1=3.6250$, F-value $=13.44$ and $\mathrm{p}$-value $=0.000$ ).

Store managers have the highest means for cheapest, premium, promoted and slow-moving brands, $($ means $=$ Right $2=3.816, \mathrm{~F}$-value $=$ 558 ; right $1=3.9551, \mathrm{~F}$-value $=85$, right $2=3.76$, F-value $=28.92$; right $2=$ $3.952 \mathrm{~F}$-value $=71.43$ and $\mathrm{p}$-value $=0.000$ ). Thus $\mathrm{H}$. 13 is supported for Horizontal positions.

For Vertical shelf space positions Top1 and Top 2, operations \& commercial department managers have the highest mean for Top1 and Top 2, for five Brands, the popular, promoted, store, well-known and 
slow-moving means $=(\operatorname{top} 1=3.6$ and Top $2=3.6250, \mathrm{~F}$-value $=22.32 ; \mathrm{p}-$ value $=0.000 ;$ Top $1=3.5794$, F-value $=189.35 ; p$-value $=0.000 ;$ Top $1=$ 3.68 , Top 2=3.55, F-value $=105.81 ; \mathrm{p}$-value $=0.000 ;$ Top $1=3.9301$ and Top 2=3.91, F-value $=65.76$ and $\mathrm{p}$-value $=0.000$ and Top $1=4.091$, Top $2=$

$\mathrm{F}$-value $=67.60$ and $\mathrm{p}$-value $=0.000$ ).

Customers have the highest Means for cheapest, mean $=$ (top $2=$ $3.816, \mathrm{~F}$-value $=597.7$, premium Top $2=3.733, \mathrm{~F}$-value $=85.10$, promoted Top $1=3.7527$, F-value $=189.35$ and new brand, Top $2=3.8618$, Fvalue $=155.85$ and $\mathrm{P}$-value $=0.000$ ).

For store managers, Top 1 has the highest means for premium mean $=3.944, \mathrm{~F}$-value $=85.10$, and new brand mean $=$ Top $1=3.736$, Fvalue $=155.58$ and $\mathrm{p}$-value $=0.000$ ).

Table (36) in appendix C shows the results of the ANOVA Test for H.13 regarding Top positions.

For Vertical Central positions there are no significant differences among the three groups of respondent with regard to the eight brands. Thus H. 13 was not supported for the Central position. Table (37) in the appendix $\mathrm{C}$ shows the results of the ANOVA test for $\mathrm{H}$. 13 regarding Central position.

For Bottom shelf space positions. Operations and commercial department managers have the highest means for Bottom 1 and 2 with regard to seven brands, premium $=$ Bottom 1 (mean $=3.88$, Bottom $2=$ 3.70 , F-value $=395.58$, Popular, Bottom 1 (mean $=3.675$, Bottom $2=$ 3.6396, F- Value $=93.8$; promoted, Bottom $1=3.67$, Bottom $2=3.6166$, F- Value $=20.41$; store, Bottom $1=3.775$; well- known, Bottom $1=$ 3.9254; Bottom $2=3.9254$, F-value $=112.70$; new Bottom $1=3.777$, Bottom $2=3.7549, \mathrm{~F}-$ Value $=162.78$; show - moving Bottom $1=4.095$ and Bottom 2 $=4.0731, \mathrm{~F}$ - value $=214.50$ and $\mathrm{P}$-value $=0.000$, and for Bottom 1 for the cheapest brand mean= 3.46 and $\mathrm{F}$-value $=26.82$, Pvalue $=0.000$ ). Customers have the highest mean for Bottom 2 with regard to the cheapest brand (mean= 3.109, F-value 26.82 and Pvalue $=0.000$ ) and store managers have the highest mean for Bottom 2 with regard to the store brand, $($ mean $=3.788 \mathrm{~F}$-value $-41.50 \mathrm{P}-$ value $=$ 0.000). Thus H. 13 was supported for Bottom positions. Table (38) in Appendix $\mathrm{C}$ shows the results of the ANOVA test for $\mathrm{H} .13$.

\section{Conclusion and Future Researches}

Current study investigates the believes that the products are spatially ordered according to perceptions of their price and quality levels, and whether brands preferences are based on their spatial Horizontal and Vertical positions. Moreover the study investigates whether the preferences of shelf space positions will differ based on the 
brand in the product category, from the perspectives of three groups of respondents, customers, operations \& commercial departments managers, and store managers, at the Coop and Al- Makhazen stores in Lebanon. The study tested 13 hypothesis, and finds support for 10 hypothesis. The results could be concluded as follows.

\subsection{Vertical shelf space positions:}

The three groups of respondents prefere Top positions over Central and Bottom positions, the preferences' means decreased from Top to Bottom with no significant differences among the three groups of respondents with this regard. These results are consistent with many prior researches, Nierop et al. (2008) suggested that items in the lowest shelves usually get less consumer attention than on the upper shelves, the items on lowers shelves therefore have lower sales and may also benefit less from promotion. Consistent with Cross (2011) regarding the preferences of Top position Heller and Robinson (2004) found that customers believe that the Top is better, as well as Schubert (2005) who stated that customers believe that product in the higher physical positions are perceived to be more powerful. Fazio, Powell and Williams (1989) found that customers believe that the products on the Top position have high prices, current study's results indicates that the perceived price means reduced as the position moved from Top to Bottom, these results are significant for the three group of respondents, and there are no significant difference among them with regard to the perceived price means of the products on the Vertical position. These results are consistent with many prior studies, Valenzuela et al. (2006) found that customers shared beliefs regarding the price of the products based on their Vertical and Horizontal shelf space. The Verticality inferences captures that the higher priced products are in Top rows. Also Valenzuela et al. (2012) explored that customers believe expensive products are placed on Top shelves.

Regarding the perceived quality of the products that are placed on different Vertical shelf space positions, perceived quality tracked those of price perceptions, for store managers group, but not for customers and operations \& commercial department managers, the latter two groups believe that quality of the products that are placed on Central positions are higher than those which are placed on Top and Bottom positions. These results are consistent with Goldstone (1989) who stated that the Central shelf space positions is very important for practitioners, they believe it increases the exposure and attentions paid to a brand, Shows (2000) recognized the advantages of the middle positions, as well as the study conducted by Valenzuela et al. (2006) which found that the products in the center of the array may represent price - quality trade - 
offs. But does not consist with the most recent study conducted by Valenzuela at el. (2012) which explored that customers believe popular products are placed on middle shelves.

\subsection{Horizontal shelf space locations:}

The three groups of respondents prefer right positions over Central and left locations, with no significant differences among them with this regards.

These results are not consistent with the studies conducted by Valenzulea and Raghubir. (2009, 2010) which found that, within the Horizontal layout, the center column is more preferred to the extreme left or right ones.

Regarding the perceived prices of the products that are placed on different Horizontal shelf space positions, the results indicate that there are significant differences related to the perceived prices of the products that are placed on different Horizontal shelf spaces positions. The price means reducing from right to left for customers and store managers, but for operations \& commercial department managers, the highest price mean is for Central position.

Results also indicate that there are significant differences related to the perceived quality of the products that are placed on different Horizontal shelf space positions for the three groups respondents. The center of the array has the highest means for customers and operation \& commercial department managers, for store managers the means of the perceived quality are reduced from right to left. Thus these results support the results of Valenzulea and Raghbir (2009) as well as Goldstone, (1989).

These the results show the importance and value of the center of the array for both orientation, Vertical and Horizontal.

\subsection{Placement Choices by Brand:}

Current study also indicates that the effect of shelf space position on product preferences varies according to brand in the product category, the Ideal, $2^{\text {nd }}$ best and worst positions are contingent on brand in the product category, the results indicate that the center of the array was chosen as the Ideal position for many brands, regarding the three groups of respondents. For customers group, it was the Ideal position for premium, popular, new and slow - moving brands, Store managers group have chosen the center of the array as the Ideal position for six brand categories, the cheapest, premium, popular, promoted, slow-moving and well-known. 
Similar to customers and store managers operations and commercial department managers have chosen the center of the array as the Ideal position for five brands, popular, slow-moving, premium, store and well- known.

The extreme left positions were chosen as the $2^{\text {nd }}$ best positions for the cheapest, well-known, new and slow moving from customer point of view, while store managers have chosen the second Bottom positions as the $2^{\text {nd }}$ best position for the cheapest, premium, popular, promoted, wellknown and the slow- moving brands. It was chosen by operations \& commercial department managers also as the $2^{\text {nd }}$ best positions for store, well-known, new and slow- moving brands. Similar to customers the second best positions for store, cheapest, well- known brands were the Bottom positions. The worst position for premium and popular brands was the second right positions, for customers group, similar to customers the store manger have chosen the second right positions as the worst position for premium, promoted, well- known and new brands. The Bottom positions were chosen as the worst positions for the cheapest, premium, popular, promoted and slow- moving brand categories.

These results indicate that the Central positions were chosen as the Ideal positions for many brands by the three groups of respondents, as in the Horizontal and Vertical orientation, which are consistent with the results of Valenzuela and Raghubir (2009, 2010), with regard to the popularity of the center position in both the Vertical orientation as well as in the Horizontal orientation. These results are also consistent with earlier findings by Christenfeld (1995) and show (2000) which indicated that customer favor items located in the middle positions.

\subsection{Implications:}

The current study indicates that customers, operations \& commercial department managers and store managers extract meaning from Horizontal and Vertical shelf space positions, thus the product position on the shelf should match its perceived meaning. For Vertical orientation, the result of the current study indicate that the three groups of respondents prefer Top position, they believe that the products that are placed on Top position have high price levels, thus expensive products should be placed on Top positions.

The results also indicate that there are significant differences among the three groups of respondents with regard to the perceived quality of the products on Vertical positions, so that the Coop \& Almakhazen Stores should follow customers schema, which means to place high priced and quality products on the Vertical center of the array, to handle the mismatch between customers, operations \& commercial department managers, and store manager's perception of the meaning of 
shelf space positions, customer should drive the planograms and the other partners should meet customer's expectations and perceptions.

For Horizontal orientations the three groups of respondents prefer the right position, so that the preferred products should be placed on the right positions.

Customers and store managers perceive products that are placed on the right positions have high price levels and the price means are reducing from right to left, so that high priced products should be placed on the right positions. Regarding the quality of the product that replaced on different Horizontal shelf space positions, customers and operations \& commercial department managers perceive the product on the center of the array as high quality products, so that the high quality products should be placed on the Horizontal center of the array. Horizontally retailers should charge premium for the right and Central positions and manufacturers should pay premium for them. Vertically, retailers should change premium for the Top and Central positions, and manufacturers should pay premium for these positions.

The current study also indicate that the effect of shelf space positions on product references varied according to the brand on product category. Ideal, $2^{\text {nd }}$ best and the worst positions are contingent on brand on the product Category. The study could specify the brand in the product category that benefit from specific shelf space positions, Coop \& AlMakhazen could benefit from these results, by placing the high priced and quality products in the brand category on the places in which they would be perceived as High Quality and priced products, each product in the product category should be placed on the suitable place for it as perceived by customers, according to the current study's results.

The current study is the first academic research based on survey conducted on the Coop \& Al-Makhazen stores, so that many replicated studies are needed on other supermarkets chain, or shopping centers to validate results obtained from this study.

The study also uses the first step at studying shelf positions and its effect on brand preferences, price, and quality in Lebanon, so that further replicate studies are needed about the relationship between shelf space positions and many other variables, for example stock outs, operating costs, sales, product attentions.

Current study is limited to eight brands, it will be more useful to the supply chain partners, if other researches try to replicate it on other brands on different product categories.

Additional researches are also needed in this area because little is known about how supply chain stages evaluate shelf space positions and extract meaning from them, specially the manufactures researches which can be conducted by doing analysis on multiple supply chains. 


\section{References}

Albeniz, V. and Roles, G. (2007), "Competing for Shelf Space," working paper, WP no: 717, Submitted to Management Science, manuscript available at: $\underline{w w w . i e s e . e d u / r e s e a r c h / p d f s / D i-0717-E-p d f}$

Bai, Rubin, Woensel, Tomvan Kendall, Graham and Burke, Edmund K. (2006), "A New Model and a Hyper- Heuristic Approach For twoخطأ! مرجع الارتباط : Dimensional Shelf Space Allocation, available at . التثعبى غير صالح.

Benek, Justin (2011), "Toward a Better Understanding of Private Label Brand Image- how Consumers Respond to in- Store Extrinsic Cues and Brand Familiarity," available at: Bai-conference.org/BAI 2011/papers /2marketing/2195.pdf.

Borin, N., Forris, P.W and Freeland, J. R. (1994), "A Model for Determining Product Category Assortment and Shelf Space Allocation," Decision Sciences, 30 (3), 359 - 384.

Breugelmans, Els, Katia Campo and ELS Gijsbrechts (2007), " Shelf Sequence and Proximity Effects in Online Stores," Marketing Letters, 18 (1-2), 117-33.

Broekmeulen, R.A.C.M., J.C. Fransoo, K.H. Van Donselaar T. and Van Woensel (2007), "Shelf Space Excesses and Shortages in Grocery Retail Stores." Tech. rep., Einthoven University Technology, The Netherlands.

Buttz, A. and Naert, p. (1988), SH. A. R. P. "Shelf Allocations For Retailers' Profit," Marketing Science, 7 (3), 211-231.

Cairns, J. P (1963), "Allocate Space for Maximum Profits", Journal of Retailing, 39 (2), 43 ff.

Chandn, Pierre, J. Welson Hutchinson, Eric T. Bradlow and Scotte Young (2007), "Measuring the Value of Point - of - Purchase Marketing with Commercial Eye - Tracking- Data", In Visual Marketing: From Attention To Action, ed. Michel Wedel and Rik Pieters, Mahwah, new-Jersey: Lawrence Elbaum Associates.

Chen, H., Daugherty, P.J. and Roath, A. (2009b), "Supply Chain Process Integration: a Theoretical Framework," Journal of Business Logistics, 30 (2), 27-46.

Chen, H., Daugherty, PJ. and Roath, A. (2009a), "Defining and Operationalizing Supply Chain Process Integration," Journal of Business Logistics, 30 (1), 63-84.

Chen, W. C. and Yang, M. H. (1999), "A Study on Shelf Space Allocation and Management," Expert systems with Applications, 32, 976986. 
Chrhan, R. C., (1972), "The Relationship Between Shelf Space and Unit Sales in Supermarkets," Journal of Marketing Research, 9, 406412.

Christenfeld, N. (1995), "Choices from Identical Options," Psychological Science. 6 (1), 50-55.

Corstjens, M., Doyle, p. (1981), “A Model For Optimizing Retail Space Allocations," Management Science, 27 (7), 822-833.

Cross, V. (2011), "Vertical \& Horizontal Merchandising Techniques," available at: http://www.ehow.com/info_8369087_Vertical_ Horizontal-merchandising-Techniques.ht.

Curhan, R.C. (1973), "Shelf Space Allocation and Profit Maximization in Mass Retailing," Journal of Marketing, (37), 54-60.

Desmet, Pierre and Valérie Renaudin (1998), "Estimation of Product Category Sales Responsiveness to All Allocated Shelf Space "International Journal of Research in Marketing", 15(5), 443457.

Drezé, X, Stephen J. Hoch and Mary E. Purk (1994), "Shelf Management and Space Elasticity," Journal of Retailing, 70 (4), 301-326.

Eroglu, Cuneyt, Brent D. Williams, Matthew A. Waller (2011), "Consumer Driven Retail Operations: The Moderating Effects of Consumer Demand and Case Pack Quantity," International Journal of physical Distribution \& Logistics management, 41 (5), 420-434.

Ettouzaui, Younis, Yales, Nicala and Mena, Carlos (2012), "Examining retail on shelf availability: Promotional Impact and a call for research," International Journal of Physical Distributional \& Logistics Management, 42 (3), 213-243.

Fanscher, L.A., (1991), "Computerized Space Management A strategic Weapon," Discount Merchandiser, 31(3), 64-65.

Fazio, Russell H., Marthc. C. Powell and Carol J. Williams (1989)," The Role of Attitude Accessibility in the Attitude- to Behavior Process," Journal of Consumer Research, 16, (3), 28-88.

Foster, J. (2002), "The Hidden Cost of Shelf Space," Business Week, April, 15.

Frank, Ronald, E. and William F. Massy (1970), "Shelf Position and Space Effects on Sales," Journal of Marketing Research, 7(1), 59-66.

Gajjor, Hasmukh and Adil, Gajendrak. (2010) "Heuristics for retail shelf space allocation problem with linear profit function," International Journal of retail \& Distribution management, 39 (2), 144-155.

Gaukler, Gary M. (2010), "Preventing available Stock out: the impact of item- level RFID in retail," Journal of Business \& Industrial Marketing, 25 (8), 572-581. 
Goldson, T.R. (1989)," Retail Shelf Space Management," The Nielsen Researcher, 2 (1), 20-24.

Grant, David B and Fernie, John (2008), "Exploring out-of-stock and onshelf availability in non-grocery, high street retailing," International Journal of retail \& Distribution Management, 36 (8), 661-672.

Gwin, Card F. (2009), "The Brand Preference to Search Relationship: An Empirical Study," available at: www.swdsi.org/swdsi2009/paper/ 902pdf.

Hansen, Jared M., Sumit Raut and Swami, Sanjeev (2010), "Retail Shelf Allocation: A Comparative Analysis Heuristic and Meta-Heuristic Approaches," Journal of Retailing, 86 (91), 94-105.

Helms, N.M., Hagnes, D.J. and Capple, S.D. (1992), "Competitive Strategies and Business Performance within the Retailing Industry," International Journal of Retail and Distribution Management., 10, 353-373.

Inman, J. Jeffrey, Leigh Mcalister and Wayne D. Hoyer (1990), "Promotion Signal: Proxy for a Price Cut?," Journal of Consumer Research, 17 (June) 74-81.

Irion, J- C, FAAL-Khayyal and Y-Ctsao (2011), "A hierarchical decomposition Approach to retail shelf space Management and assortment decisions," Journal of the Operational Research Society, 62 (October) 1861-1870.

Khan, Adeel, A and Mudassar Asghar (2010) "Impact of Shelf Space and Other Products Cues on the Selection of FMCG Products in Grocerg Store". Unpuplished Dissertation School of Management, Blekinge Institute, of Technology, Karlskrona.

Koschat, M.A. (2008), "Store Inventory Can Affect Demand: Empirical Evidence from Magazine retailing," Journal of retailing, 84 (2), $165-179$.

Lefebure, Joanna (2007), “Food Management”, Ups and Down of Visual Merchandising, (Nov.) 27, 2007.

Levy, M., and Weitz, B. (1995), "Retailing Management", Irwin, Chicago. Lim, A, B. Rodrigues and X. Zhang, (2003), "Meta- Heuristics with Local Search Techniques for Retail Shelf space Optimization," available at: Acadepedia.com/Andrew/ mages/course/PAPERS/MS2003 al.pdf.

Lindblom, A. and Olkkonen, R. (2006), "Category Management Tactics: An Analysis of Manufactures Control," International Journal of Retail \& Distribution Management, 34 (6), 482-496.

Mckinsey - General Food Study (1963), The Economics of Food Distribution, New York: General Food. 
Murry, Chase C., Talukdar, D. and Gosavi, A. (2010), "Joint Optimization of Product Price, Display Orientation and Shelf-Space Allocation in Retail Category Management." Journal of Retailing, $(\times \times$, 2010,), doi: 10.1016/J. Jretai.2010..20.008.

Nachmann, it. Jwaller, M.A. and Rieske, D. (2010), "The Impact of pointof-sale data inaccuracy and inventory record data errors," Journal of Business Logistics, 31 (1), 194-158.

Nelson, E. and Ellision, S. (2005), "Shelf Promotion: in a Shift, Marketers Beef up ad Spending Inside Stores," The Wall Street Journal, 21 (1), A. 1.

Nierop, Erjen Van, Fok, Dennis and Franses, Hans (2008), "Interaction Between Shelf Layout and Marketing Effectiveness and its Impact on Optimizing Shelf Arrangements," Marketing Science, 1 - 19.

Nisbett, R.E and T.D mission (1977), "Telling More Than we Can Know: Verbal Reports on Mental Processes," Psychological Review, 84 (3), 231-259

Raghubir, priya and Ana Valenzuela (2006)," Center of Inattention: Position Biases in Decision Making," Organizational Behavior and Human Decision Processes, 99 (1), 66-80.

Ratchford, B. T. (2003), "Has the Productivity of Retail Food Stores Really Declined," Journal of Retailing, 79 (3), 171-182.

Rettie, Ruth, and Carol Brewer (2000), "The Verbal and Visual Components of Package Design," Journal of product and Brand Management, 9 (1), 1-21.

Richey, G.R.Jr, Roath, A.S., Whipple, J.M. AND FAW CETT, S.E (2010),"Exploring a Governance Theory of Supply Chain Management: Barriers and Facilitators to Integration", Journal of Business Logistics, 31 (1), 237-56

Rouse, Margaret (2010), "Planogram definition", available at: what is techtarget.com/definition/planogram.

Schubert, Thomas (2005), "Your Highness: Vertical Position as Perceptual Symbols of Power," Journal of Personality and Social Psychology, 89 (1), 1-21.

Schubert, Thomas (2005). "Your Highness: Vertical Positions as Perceptual Symptoms of Power," Journal of personality and Social Psychology, 9 (1), 1-21.

Shaw, J. I. (2000). "Centrality preferences. In Choices Among Similar Options," Journal of General Psychology, 127, (2), 157-164.

Simonson, Itamar and Amos Tversky (1992), "Choice in Context: Tradeaff Contrast and Extremeness Aversion", Journal of Marketing research, 29 (August), 281-295. 
Simonson, J. (1993), "Get Closer to your consumer by Understanding How They Make Choices," California Management Review, 35 (4), 227-229.

Smith, (2011), "Improving your planogram quality," available at:

Suarez, Monica, G. (2005), "Shelf Space Assigned to Store and National Brands: A Neural Network Analysis," International Journal of Retail \& Distribution Management, 33 (11), 858-878.

Tull, G., and Hawkins, D. (1993), "Marketing research: Measurement and Methods," New York: McMillan Publishing Company.

Urban, T.L. (1998), "An Inventory - Theoretic Approach to Product Assortment and Shelf Space Allocation," Journal of Retailing, 74 (1), 15-35.

Valenzuela, Ana and Priya Raghubir, (2009), "Position Based Schemas: The Center- Stage Effect", Journal of Consumer Psychology, 9 (2), 185-196.

Valenzuela, Ana and Raghubir, Priya (2010), "Are Consumer Aware of Top-Bottom But Not of Left-Right Inferences?," Implications for

Shelf Space Positions, available at: /www.econ.upf.edu/ dos/seminois/ Valenzuela.PDF

Valenzuela, Ana, Raghubir, Priua and C.Mitakakis (2012), "Shelf Space Schemas: Myth or Reality?," Journal of Business of Realty, available at: http://www.sciencedirect.com/science/article/pii/ soi4829 6311004139.

Walters, R.G., Bommer, W. (1996), "Measuring The Impact of Product and Promotion- Related Factors on Product Category Price Elasticties," Journal of Business research, (36), 203- 216.

Woensel, R.A.C.M Broekmeuten, K.H. Van Donselaar, J.C. Franasoo (2006), "Planogram Integrity: a Serious Issue". Accepted by ECR Journal, available at: www.asap.cs.nott.ac.uk/?q=bibliography \&page $=8 \&$ sort=title.

Yang, M. (2001), "An Efficient Algorithm to allocate shelf space," European Journal of Operations Research, 131 (1), 107-118.

Yang, M. H, W. - C. Chen (1999), "A Study on Shelf Space Allocation and Management," Production Economic, 60, 309-317.

Zeithaml, V.A. (1988), "Consumer Perception of Price, Quality and Value: A Means-end Model and Synthesis of Evidence," Journal of Marketing, 52 (July), 2-22.

Zufryden, F. (1986), "A Dynamic Programming Approach for Product Selection and Supermarket Shelf - Space Allocation," Journal of the Operational Research Society, 37 (4), 413 - 422. 


\section{Appendixes}

\subsection{Appendix A.1}

A List of the names, address, and phone numbers of the coop and Al makhazen Company branches

\begin{tabular}{|c|c|c|}
\hline Number Phone & Address & Branches \\
\hline 01-852801 & Sabra, Al Mufti Hassan Khaled, Beirut & Sabra \\
\hline $01-801597$ & White Sand junction Oger Lebanon building sand & Ramlet \\
\hline $01-310114$ & $\begin{array}{c}\text { Tower Abu Abd al-Ghani Haidarstreet Aerysi pharmacy Almaoi } \\
\text { near Beirut }\end{array}$ & Burj Abi Haidar \\
\hline $01-376510$ & $\begin{array}{c}\text { Abu Bakr al-Siddiq Street, last sorties Mareliass, near the oven } \\
\text { Shami, building Gager }\end{array}$ & Mussaitbeh \\
\hline $01-348465$ & $\begin{array}{c}\text { Hamra Street - Jerusalem, building bayoud, compared with } \\
\text { Marble Tower Hotel, Beirut }\end{array}$ & Hamra \\
\hline $01-559075$ & Street Asaad Al-Assad, building Hebron, the southern suburbs & Chiah \\
\hline $01-365821$ & Alottoat Street, Alottoat, Tower Building the future, Beirut & Watwet \\
\hline $01-662761$ & Basta, near the police station & Basta \\
\hline $01-365324$ & Remarkably, near a school Lycee Abdel Kader & Zarif \\
\hline 05-801140/1 & Khaldeh, public highway, by Ben Matouk, building cooperative & Khaldeh \\
\hline $05-410227$ & $\begin{array}{c}\text { Square Cyprhmon, towards the Bank of Beirut and the Arab } \\
\text { countries, building Ayash, Cyprhmon }\end{array}$ & Quabr Shmoun \\
\hline $07-530915$ & $\begin{array}{c}\text { Of al-road, near the junction Habbush, King Mohammed } \\
\text { Mantash }\end{array}$ & Nabatieh \\
\hline $07-971223$ & $\begin{array}{c}\text { Katrmaya Street, Friesen, along with sweets Jubouri, the } \\
\text { province of carob }\end{array}$ & Ketermaya \\
\hline $05-720493$ & Al-Shouf - Damit - Road - Almsalbip & Manassef \\
\hline $05-500420$ & The public highway, Choice center & Simkanieh \\
\hline $\begin{array}{l}05-551246 \\
05-559920\end{array}$ & $\begin{array}{c}\text { High near the municipal stadium, neighborhood elders, Mount } \\
\text { Lebanon }\end{array}$ & Alay/Malaab \\
\hline $05-553158$ & King Street Albesen "Ziad Talhouq" & Alay/Piscine \\
\hline $05-811869$ & $\begin{array}{c}\text { Aramoun Alcouba - the main street by the Bank of Lebanon and } \\
\text { the Diaspora }\end{array}$ & Doha Aramoun \\
\hline 05-813826-7 & Bshmoun-Main Street-Facing AL Zaaini Factory & Bsmoun \\
\hline $05-530894$ & $\begin{array}{c}\text { Castle, through the year Hamana - Karnayel, Salah al-Masri } \\
\text { building near a bank of resources, Mount Lebanon }\end{array}$ & Falougha \\
\hline $08-544227 / 8$ & $\begin{array}{c}\text { Chtaura, Center Shramoul, compared to junction Kab Elias, } \\
\text { Bekaa }\end{array}$ & Chtoura \\
\hline $08-950527$ & Fourzol, public highway, near the ovens Piper, the Bekaa & Forzol \\
\hline $08-372955$ & $\begin{array}{l}\text { Baalbek, a neighborhood Sharawna, building Hanadi Wehbe, } \\
\text { the Bekaa }\end{array}$ & Baalback \\
\hline 08-663010 & $\begin{array}{c}\text { Junction Jeb Jenin / opaque almonds - King Rahal - as opposed } \\
\text { to the return of Bank }\end{array}$ & Jeb jenin \\
\hline 04-541982 & Awkar, Metn North / Mount Lebanon & Awkar \\
\hline \multirow[t]{2}{*}{$04-860312$} & Broumana, the Mar Chaaya, Mount Lebanon & Broumana \\
\hline & Taalabaya -Main Street Facing Al Shaab pharmacy & sheet \\
\hline $05-430525 / 6$ & Choueifat, Altero & MainWarehouse \\
\hline $01-317378$ & Burj Abu Haidar, near the cooperative, Beirut & Maintenance \\
\hline 05-805377 & Choueifat / dome building and a good hard & Meat Warehouse \\
\hline $01-858498$ & $\begin{array}{c}\text { Round-cola, near the Engineers Association, Syrian Social } \\
\text { building and safety, Beirut }\end{array}$ & $\begin{array}{c}\text { Madina } \\
\text { Warehouse }\end{array}$ \\
\hline $\begin{array}{c}03-731831 \\
01-450226 / 7 / 8\end{array}$ & Old Airport Road - near Heritage School & Head Office \\
\hline
\end{tabular}




\section{Appendix A.2}

Customers, sales value TVA; basket + TVA for the Coop Stores in Lebanon

Periodical Sales Comparison from 01/01/2010 to 31/12/2010

\begin{tabular}{|c|c|c|c|c|c|c|c|c|c|c|c|c|c|}
\hline GR Total & $6,523,892$ & $6,902,6$ & & 114,246 & ,887,502 & 5,895 & 4.21 & 17,597 & 17,303 & $-1.67 \%$ & $, 749,887,609-9,698$ & $8,901,714$ & $-7.53 \%$ \\
\hline Branch & Prev-Cust\# & Cur-Cust\#\# & Variance & Prev-Y-Sales & Cur-Y-Sales & ¿ Sales & Variance & Prev-Basket & Cur-Easket & Variance & Budget & Diff & variance \\
\hline $\begin{array}{l}\text { SABRA } \\
\text { RART }\end{array}$ & 433,978 & 427.448 & -1.508 & $8,844,162,320$ & $8,551,207,029$ & $\begin{array}{l}7.19 \% \\
5.46 \%\end{array}$ & $-3.20 \%$ & 20,416 & 20,057 & $-1.76 \%$ & $9.594,526.873$ & $-1,033,319,849$ & $-10.77 \%$ \\
\hline $\begin{array}{l}\text { RANILET } \\
\text { VERDUN }\end{array}$ & $\begin{array}{l}331,919 \\
183,537\end{array}$ & $\begin{array}{l}315,939 \\
170,355\end{array}$ & $\begin{array}{r}-4.80 \% \\
-10.12 \%\end{array}$ & $7,144,059,538$ & $8,499,316,218$ & $5.46 \%$ & $-9.02 s$ & 21,740 & 20,571 & $-5.38 \%$ & $7,849,569,777$ & $-1,350,253,559$ & -17.208 \\
\hline RASBEIRUT & $\begin{array}{l}189,537 \\
249,501\end{array}$ & $\begin{array}{l}170,355 \\
238,327\end{array}$ & $\begin{array}{r}-10.12 \frac{8}{6} \\
-4.438\end{array}$ & $3,240,113,244$ & $2,889,030,082$ & $2.43 \%$ & -10.818 & 17,134 & 16,959 & -1.025 & $3,527,178,278$ & $-638,147,396$ & -18.096 \\
\hline HAI DAR & 281,746 & 286,496 & $\begin{array}{r}-4.438 \\
1.69 \%\end{array}$ & $\begin{array}{l}3,296,719,153 \\
3,698,441,201\end{array}$ & $\begin{array}{l}3,250,922,412 \\
3,738,718,046\end{array}$ & $\begin{array}{l}2.738 \\
3.148\end{array}$ & $-1.39 \%$ & 13,295 & 13,641 & 2.608 & $3,550,452,348$ & $-299,529,936$ & $\begin{array}{l}-8.44 \% \\
-7.55 \%\end{array}$ \\
\hline MSEITBEH & 213,442 & $195,38 \mathrm{~B}$ & -8.468 & $3,024,047,029$ & $2,743,063,219$ & $\begin{array}{l}3.148 \\
2.308\end{array}$ & $1.09 \%$ & 13,135 & 13,050 & $-.65 \%$ & $4,048,487,060$ & $-309,769,014$ & $-7.65 \%$ \\
\hline HAMRA & 580,164 & 593.399 & $2.28 \%$ & $\varepsilon, 016,806,936$ & $8,080,784,170$ & $\begin{array}{l}2.308 \\
6.798\end{array}$ & $\begin{array}{r}-11.068 \\
.80 \%\end{array}$ & $\begin{array}{l}14,449 \\
13,062\end{array}$ & $\begin{array}{l}14,039 \\
13,613\end{array}$ & -2.843 & $3,380,935,918$ & $-637,872,699$ & $\begin{array}{r}-18.87 \% \\
-7.34 \%\end{array}$ \\
\hline $\mathrm{Z} \cdot \mathrm{RIF}$ & 238,140 & 255,242 & $7.18 \%$ & $2,928,129,623$ & $3,130,703,878$ & $2.63 \%$ & $6.92 \%$ & $\begin{array}{l}13,362 \\
12,296\end{array}$ & $\begin{array}{l}13,613 \\
12,266\end{array}$ & $-1.75 \%$ & $8,721,231,353$ & $-640,447,183$ & $\begin{array}{r}-7.34 \% \\
-.76 \%\end{array}$ \\
\hline BASTA & 312,016 & 331,322 & $6.19 \%$ & $3,132,743,425$ & $3,166,891,038$ & $2.66 \%$ & $1.09 \%$ & 10,040 & $\begin{array}{r}12,266 \\
9,559\end{array}$ & $-.25 \%$ & $3,154,701,985$ & $-23,998,107$ & $-.76 \%$ \\
\hline MARLIAS & 288,307 & 301,988 & $4.75 \%$ & $2,649,512,400$ & $2,583,738,308$ & $2.17 \%$ & $-2.48 \%$ & 9,190 & $\begin{array}{l}9,556 \\
8,556\end{array}$ & -4.803 & $3,345,848,959$ & $-178,957,921$ & $-5.35 \%$ \\
\hline CHIAH & 233,756 & 240,665 & $2.96 \%$ & $2,792,353,153$ & $2,764,223,558$ & $2.32 ?$ & $-1.01 \%$ & 11,946 & $\begin{array}{r}8,556 \\
11,456\end{array}$ & $-6.90 \%$ & $2,882,247,291$ & $-293,448,983$ & $-10.35 \%$ \\
\hline WETWAT & 151,929 & 142,320 & $-6.32 \%$ & $1,709,174,358$ & $1,590,392,207$ & & & 11,250 & 11,456 & $-3.85=$ & $3,014,405,823$ & $-250,177,325$ & -8.309 \\
\hline BEIRUT & $3,504,435$ & $3,498,939$ & -.168 & $\overline{50,536,262,383}$ & $48,999,055,965$ & 41.348 & -6.958 & $\begin{array}{l}11,250 \\
14,462\end{array}$ & 11,175 & -.678 & $2,379,627,181$ & $-739,234,974$ & $-33.17 \%$ \\
\hline & & & & & & 41.168 & $-3.04:$ & & 14,008 & $-3.14 \%$ & $55,449,212,911$ & $-6,450,150,946$ & $-11.63 \%$ \\
\hline Branch & Prev-Cust\# & Cur-Cust\# & Variance & Prev-Y-Sales & Cur-Y-Sales & 8 Sales & Variance & Prev-Basket & Cur-Basket & Variance & Budget & Diff & Variance \\
\hline ALEY & 192,004 & 194,438 & $1.27 \%$ & $5,390,059,974$ & $5,274,530,203$ & 4.438 & $-2.14 \%$ & 23,124 & 27,186 & $-3.34 \mathrm{z}$ & $5,945,908,939$ & $-671,376,736$ & $-11.29 \%$ \\
\hline FFLOUGHA & 172,312 & 179,403 & $4.12 \%$ & $4,533,356,402$ & $\begin{array}{l}4,726,073,551 \\
1,333,017,864\end{array}$ & $3.97 \%$ & 4.258 & 26,309 & 26,343 & $.13 \frac{2}{8}$ & $4,934,455,091$ & $-208,411,540$ & $-4.22 \%$ \\
\hline BHAMDOUN & & 54,273 & $\%$ & & $1,333,617,864$ & 1.128 & & & 24,895 & \% & $1,130,619,720$ & $202,998,135$ & $17.95 \%$ \\
\hline AWKAR & 231,696 & 225,453 & -2.698 & $3,036,017,077$ & $2,977,393,671$ & 2.508 & -3.528 & 13.319 & 13,206 & -.858 & $3,370,424,845$ & $-393,031,174$ & $-11.66 \%$ \\
\hline BAZLEAK & 79,292 & 76,947 & $-2.96 \%$ & $1,434,762,111$ & $1,416,534,190$ & $1.19:$ & -1.278 & 18,095 & 18,409 & $1.74 \%$ & $1,567,599,958$ & $-151,065,768$ & $-9.61 \%$ \\
\hline BROUMANA. & 197,654 & 200,373 & $1.38 \%$ & $3,972,650,132$ & $4,039,494,916$ & 3.390 & $1.68 \%$ & 20,099 & 20,160 & $.30 \%$ & $4,322,971,877$ & $-283,476,961$ & -6.568 \\
\hline JEBJ NINE & 71,05 & 102,472 & 44.219 & $1,413,725,380$ & $2,101,508,445$ & $1.77 \hat{\mathrm{y}}$ & 42.658 & 19,895 & 20,508 & 3.088 & $2,279,921,322$ & $-178,412,877$ & -7.839 \\
\hline ZLEY-NEW & 15,263 & 124,184 & $682.85 \%$ & $264,082,714$ & $1,904,306,051$ & $1.60 \%$ & $621.10 \%$ & 16,0 & 15,335 & $-7.89 \%$ & $1,130,620,673$ & $773,685,378$ & $63.43 \%$ \\
\hline FOURZOL & 145,174 & 153,115 & $5.47 \varepsilon$ & $2,547,518,989$ & $2,774,565,750$ & $2.33=$ & $8.91 \%$ & 17,548 & 13,121 & 3.268 & $2,7 € 2,805,244$ & $11,760,516$ & .438 \\
\hline SHTOUEA & 161,887 & 168,641 & 4.178 & $5,135,610,528$ & $4,979,118,318$ & $4.1 \leq 8$ & -3.053 & $31,72.3$ & 29,525 & -6.938 & $5,829,595,287$ & $-850,476,969$ & -14.598 \\
\hline BEKAA \& & $1,266,940$ & $1,479,290$ & $16.76 \%$ & $27,777,793,307$ & $31,527,142,968$ & $26.48 \overline{6}$ & $13 . \overline{50 \%}$ & 21,033 & $21,3 \overline{32}$ & -2.748 & $33,274,952,964-$ & $-1,747,809,996$ & $-5.25 \%$ \\
\hline Branch & Prev-Cust\# & Cur-Cust\# & Variance & Prev-Y-Sales & Cur-Y-Sales & $\because$ Sales & Variance & Prer-Basket & Cur-Basket & Variance & Budget & Diff & Variance \\
\hline TRIFO_MARD & $194, \overline{361}$ & 181,502 & -6.628 & $2,956,305,904$ & $2,738,711,136$ & 2.305 & -7.678 & 15,262 & 15,089 & $-1.13 \%$ & $3,221,631,502$ & $-482,920,466$ & -14.993 \\
\hline TRIPO_COND & & 50,539 & \& & & $637,857,439$ & .528 & & & 12,621 & 3 & & $637,857,439$ & \\
\hline TRIPO_IAINA & & 11,575 & 3 & & $124,259,341$ & .108 & & & 10,735 & 8 & & $124,25 ?, 341$ & \\
\hline TRIEO_SAKA & & 2,453 & 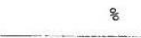 & & $23,615,017$ & $.02 \%$ & & & 9,627 & 흥 & & $23,615,017$ & \\
\hline NORTH & 194.361 & $246, \overline{063}$ & 26.608 & $2,966,305,904$ & $3,524,442,932$ & 2.968 & 18.828 & 15,262 & 14,523 & -6.158 & $3,221,631,602$ & $302,811,330$ & 9.108 \\
\hline Branch & Prev-Cust\# & Cur-Cust\# & Variance & Prev-Y-Eales & Cur-Y-Sales & S Sales & Variance & Prev-Basket & Cur-Basket & Variance & Budget & Diff & Variance \\
\hline KHALDE & 479,008 & 447,272 & -6.633 & $13,924,020,754$ & $12,897,717,716$ & 10.838 & $-7.37 \%$ & 29,903 & 29,593 & -1.048 & $15,079,910,939-$ & $-2,132,193,223$ & -14.478 \\
\hline HENASSEF & 154,993 & 158,091 & $2.00 \%$ & $2,791,256,415$ & $2,875,884,354$ & 2.428 & 3.128 & 13,009 & 13,217 & $1.15 \mathrm{~s}$ & $3,035,090,525$ & $-155,206,171$ & $-5.11 \mathrm{~s}$ \\
\hline SHHOUN & 225,788 & 230,501 & $2.09 \%$ & $3,489,193,5 \div 1$ & $3,882,749,083$ & $3.26 \%$ & 11.288 & 15,453 & 16,852 & 3.058 & $3,862,084,682$ & $20,661,401$ & $.54 \%$ \\
\hline NAEATIEH & 137,946 & 4,079 & $-2.80 \%$ & $3,626,439,585$ & $3,340,131,281$ & $2.81 \mathrm{~s}$ & -7.908 & 26,289 & 24,912 & $-5.24 \%$ & $3,935,197,775$ & $-595,066,494$ & $-15.12 \%$ \\
\hline SEMKANIEH & 140,320 & 144,696 & $3.12 \mathrm{~s}$ & $2,399,521,100$ & $2,585,092,237$ & $2.17 \%$ & 7.868 & 17,100 & 17,886 & 4.608 & $2,587,233,331$ & 858,846 & .038 \\
\hline KETERHAYA & 208,571 & 3,171 & 2.218 & $3,483,778,559$ & $3,789,555,773$ & $3.18 \%$ & $3.78 \$$ & 16,703 & 17,777 & $6.43 \%$ & $3,697,829,154$ & $91,726,619$ & 2.408 \\
\hline DARAYA & 105,310 & 119,032 & $13.03 \%$ & $1,577,712,165$ & $1,725,544,860$ & $1.45 \mathrm{~s}$ & 9.378 & & 14,496 & -3.248 & $1,708,467,358$ & $17,077,002$ & 18 \\
\hline $\begin{array}{l}\text { BARJA } \\
\text { ARIIIOUN }\end{array}$ & 106,220 & $\begin{array}{l}108,133 \\
123,332\end{array}$ & $\begin{array}{r}1.80 \% \\
8\end{array}$ & $574,603,769$ & $\begin{array}{l}1,567,070,413 \\
2,329,598,314\end{array}$ & $\begin{array}{l}1.32 \% \\
1.96 \%\end{array}$ & -6.428 & 15,765 & 14,492 & -8.088 & $1,767,656,080$ & $-200,585,567$ & -11.358 \\
\hline
\end{tabular}


Periodical Sales Comparison from 01/01/2011 to 31/12/2011

\begin{tabular}{|c|c|c|c|c|c|c|c|c|c|c|c|c|c|}
\hline Branch & Prev-Cust\# & Cur-Cust\# & Variance & Prev-y-Sales & Cur-Y-Sales & 8 Sales & Variance & Prev-Basket & Cur-Basket & Variance & Budget & Diff & Variance \\
\hline SABRA & 360,046 & 337,849 & -6.178 & $7,177,786,107$ & $7,131,252,174$ & $6.98 \mathrm{z}$ & $-.65 \%$ & 19,965 & 21,138 & $5.88 \%$ & $7,671,191,499$ & $-539,939,325$ & -7.048 \\
\hline RAMLET & 266,488 & 249,429 & $-6.40=$ & $5,470,097,791$ & $5,306,397,218$ & $5.20 \%$ & -2.993 & 20,530 & 21,274 & $3.63 \%$ & $5,712,564,892$ & $-406,167,674$ & -7.118 \\
\hline VERDUN & 144,347 & 132.376 & -8.298 & $2,426,334,091$ & $2,408,653,525$ & 2.368 & -.738 & 16,809 & 18,196 & $8.25 \%$ & $2,532,998,198$ & $-124,344,673$ & $-4.91 \%$ \\
\hline RASBEIRUT & 204,961 & 169,355 & -17.375 & $2,775,526,634$ & $2,455,668,101$ & $2.40 \%$ & $-11.52 \%$ & 13,542 & 14,500 & $7.08 \%$ & $2,099,420,281$ & $-4: 3,752,180$ & $-15.30 \%$ \\
\hline HAI DAR & 237,949 & 242,464 & $1.90 \%$ & $3,091,541,694$ & $3,275,178,516$ & $3.21 \%$ & $5.94 \%$ & 12,992 & $13,50 ?$ & 3.978 & $3,623,265,513$ & $-349,086,997$ & -9.618 \\
\hline MSEITBEH & 164,859 & 145,360 & -11.835 & $2,298,057,981$ & $2,121,786,039$ & $2.08 \%$ & -7.678 & 13,940 & 14,597 & 4.718 & $2,399,219,747$ & $-277,433,700$ & $-11.56 \%$ \\
\hline HAMRA & 494,003 & 524,672 & $6.21 \%$ & $6,704,006,215$ & $7,399,479,636$ & $7.24 \%$ & $10.37 \%$ & 13,571 & 14,103 & 3.928 & $7,063,304,496$ & $336,175,140$ & $4.76 \%$ \\
\hline ZARIF & 211,793 & 240,013 & 13.325 & $2,585,700,907$ & $3,064,249,264$ & $3.00 \%$ & 18.518 & 12,209 & 12,767 & $4.57 \mathrm{~s}$ & $2,770,117,646$ & $294,131,618$ & 10.628 \\
\hline EASTA & 277.876 & 269,772 & $-2.92 \%$ & $2,641,953,773$ & $2,686,355,376$ & $2.63 \%$ & $1.6 \mathrm{Bs}$ & 9,508 & 9,958 & $4.74 \%$ & $2,757,341,428$ & $-71,496,052$ & $-2.59 \%$ \\
\hline MARLIAS & 251,416 & 257,448 & $2.40 \%$ & $2,129,478,533$ & $2,391,748,593$ & $2.34 \%$ & $12.32 \%$ & 8,470 & 9,290 & $9.68 \%$ & $2,220,261,079$ & $171,437,514$ & 7.725 \\
\hline СHIAH & 203,745 & 188,462 & -7.508 & $2,325,540,166$ & $2,256,888,750$ & $2.21 \mathrm{~s}$ & $-2.95 \%$ & 11,414 & 11,975 & 4.925 & $2,325,246,075$ & $-68,357,325$ & $-2.94 \%$ \\
\hline WETWAT & 122,747 & 75,993 & -38.098 & $1,365,685,656$ & $778,778,816$ & $.76 \%$ & -42.968 & 11,126 & 10,248 & -7.898 & $1,461,650,426$ & $-682,871,610$ & $-46.72 \%$ \\
\hline BEIRUT & $2,940,230$ & $2,833,193$ & $-3.64 \%$ & $40,991,709,550$ & $41,27 \overline{6,436,008}$ & 40.418 & $.69 \%$ & 13,946 & 14,572 & 4.508 & \multicolumn{2}{|c|}{$43,437,081,280-2,160,645,272$} & -4.97 \\
\hline Branch & Prev-Cust\# & Cur-Cust\# & Variance & Prev-Y-Sales & Cur-Y-sales & : Sales & Variance & Prev-Basket & Cur-Basket & variance & Budget & Diff & Variance \\
\hline ALEY & 156,747 & 156,631 & -6.078 & $4,564,059,113$ & $4,434,511,483$ & $4.34 \%$ & $-2.84 \%$ & 27,431 & 28,368 & 3.428 & $4,545,516,239$ & $-111,004,756$ & $-2.44 \%$ \\
\hline FALOUGHA & 158,293 & 136,371 & -13.858 & $4,200,669,934$ & $3,604,203,338$ & 3.598 & $-12.77 \%$ & 26,537 & 20,369 & 1.258 & $4,375,954,036$ & $-711,750,648$ & $-16.27 \%$ \\
\hline BHFHLOUN & 49,861 & 45,158 & -9.438 & $1,251,053,923$ & $1,152,563,255$ & $1.13 \%$ & -7.879 & 25,442 & 25,639 & .788 & $2,720,395,000$ & $-1,567,831,745$ & -57.638 \\
\hline AWKAR & 190,012 & 175,571 & -7.608 & $2,480,844,647$ & $2,575,090,584$ & $2.52 \%$ & $3.80 \%$ & 13,056 & 14,667 & 12.348 & $2,480,805,707$ & $94,234,877$ & 3.808 \\
\hline BAALBAK & 65,302 & $6 i, 389$ & $-1.40 \mathrm{~s}$ & $1,202,895,558$ & $1,190,457,025$ & $1.17 \%$ & $-1.03 \%$ & 18,421 & 18,499 & $.37 i$ & $1,202,644,531$ & $-12,187,506$ & $-1.01 \%$ \\
\hline EROUMFANA & 169,755 & 165,260 & $-2.65 \%$ & $3,411,311,684$ & $3,313,515,340$ & $3.24 \%$ & $-2.87 \%$ & 20,096 & 20,050 & -.228 & $3,410,528,292$ & $-97,012,952$ & -2.848 \\
\hline JEBJANINE & 87,167 & 93,705 & $7.50 \%$ & $1,759,998,157$ & $2,206,295,362$ & $2.16 \%$ & 25.368 & 20,191 & 23,545 & 16.618 & $1,832,009,438$ & $374,285,924$ & $20.43=$ \\
\hline ALEY-NEW & 105,922 & 107,412 & 1.413 & $1,624,187,054$ & $1,663,957,643$ & $1.63 \%$ & $2.45 \%$ & 15,334 & 15,491 & $1.03 \%$ & $1,693,655,579$ & $-29,697,936$ & $-1.75 \%$ \\
\hline FOURZOL & 131,883 & $125,4 \varepsilon 2$ & -4.85 & $=, 342,177,678$ & $2,406,574,153$ & 2.363 & $2.75 \%$ & 17,760 & 19,179 & 7.995 & $2,442,550,042$ & $-35,975,839$ & $-1.47 \%$ \\
\hline SHTOUR: & 143,112 & 132,986 & $-7.08:$ & $4,231,374,607$ & $3,935,255,327$ & $3.85 \%$ & -7.008 & $29,5 \in 7$ & 29,592 & .088 & $4,411,319,043$ & $-476,063,716$ & -10.799 \\
\hline BEKAA \& & $1,268,054$ & $1,202,965$ & $-5.13:$ & $27,068,572,463$ & $26,542,423,560$ & $25.99 \%$ & -1.948 & 21,368 & 22,076 & $3.31 \%$ & \multicolumn{2}{|c|}{$29,115,377,907-2,572,954,347$} & $-8.84 \%$ \\
\hline Branch & Prev-Cust\# & Cur-Cust\# & Variance & Prev-Y-Sales & Cur-Y-Sales & sales & Variance & Prev-Basket & Cur-Basket & Variance: & Budget & Diff & Variance \\
\hline TRIPO_MARD & 153,956 & 135,499 & -11.99 & $2,316,839,127$ & $2,075,997,233$ & 2.038 & $-10.40 \%$ & 15,049 & 15,321 & 1.815 & $=, 420,100,050$ & $-344,102,857$ & -14.228 \\
\hline TEIPO_COND & 32,979 & 30,659 & $174.90 \%$ & $423,724,881$ & $1,109,960,912$ & $1.09 \%$ & $161.95 \%$ & 12,348 & 12.243 & -4.718 & $1,520,000,000$ & $-410,039,088$ & -26.989 \\
\hline TRIPO_MINA & 489 & 62,110 & 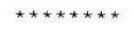 & $7,145,465$ & $687,803,806$ & $.67 \frac{\mathrm{o}}{8}$ & 9525.748 & 14,612 & 11,074 & -24.228 & $1,520,000,000$ & $-332,196,194$ & -54.758 \\
\hline TRIPO_SAKA & & 77.082 & $\frac{8}{8}$ & & $684,158,045$ & .678 & & & 8.876 & 8 & $1,21 \varepsilon, 000,000$ & $-531,841,955$ & $-43.74 \%$ \\
\hline NORTH & 187,424 & 365,350 & $94.93 \mathrm{~b}$ & $2,747,709,473$ & $4,557,919,996$ & 4.468 & $65.88 \%$ & 14,660 & $1 2 \longdiv { 4 7 5 }$ & -14.908 & \multicolumn{2}{|c|}{$6,676,100,090-2,118,180,094$} & -31.738 \\
\hline Branch & Prev-Cust\# & Cur-Cust\# & Variance & Prev-Y-Sales & Cur-Y-Sales & S sales & Variance & Prev-Basket & Cur-Basket & Variance & Budget & Diff & Variance \\
\hline KHALLDE & 381,463 & 309,304 & $-18.90 \%$ & $10,000,914,044$ & $9,530,274,522$ & 9.33 & $-12.57 \%$ & 29.322 & 31,396 & 7.072 & $11,166,002,635$ & $1,635,728,163$ & -14.658 \\
\hline MNAS $\$ E F$ & 134,250 & 126,859 & -5.518 & $2,428,984,972$ & $2,445,423,795$ & 2.398 & .608 & 12.093 & 19,277 & 6.548 & $2,535,099,030$ & $-89,675,235$ & -3.548 \\
\hline SHMOUN & 195,564 & 194.577 & $-.50 \%$ & $3,273,529,816$ & $3,390,280,360$ & 3.328 & 3.418 & 16.773 & 17,424 & $3.83 \%$ & $3,442,367,788$ & $-52,087,428$ & -1.518 \\
\hline NABATIEH & 115,300 & 95,010 & -17.603 & $2,874,172,203$ & $2,341,907,617$ & $2.29 \%$ & $-18.52 \%$ & 24,928 & 24,649 & $-1.12 \%$ & $2,994,813,383$ & $-652,905,766$ & $-21.80 €$ \\
\hline SEMKANIEH & 2,164 & 123,420 & $1.03 \%$ & $2,183,904,960$ & $2,292,186,734$ & 2.223 & $4.96 \%$ & 17.877 & $18,57=$ & 3.398 & $2,183,556,451$ & $108,6 \leq 0,283$ & $4.97 \%$ \\
\hline KETER:AAYA & 180,427 & 180,510 & .108 & $3,205,019,393$ & $3,349,040,617$ & $3.28 \%$ & 4.468 & 17,769 & 18,543 & $4.36 \%$ & $3,338,604,243$ & $10,436,374$ & .318 \\
\hline DERAYA & 100,945 & 100,391 & $\begin{array}{l}-.55= \\
-2.85=\end{array}$ & $1,463,926,890$ & $1,587,589,=98$ & $1.55 \%$ & 8.452 & 14,502 & 15,814 & $9.05 \%$ & $1,524,138,905$ & $02,450,393$ & 4.168 \\
\hline BARUS. & 92,558 & 89,922 & $-2.85 \$$ & $1,340,624,722$ & $1,270,912,529$ & $1.24 s$ & $-5.20 \%$ & 14,484 & 14,133 & -2.428 & $1,396,690,713$ & $-125,778,134$ & $-9.01 \mathrm{~s}$ \\
\hline AR:MOUN & 89,415 & 206,295 & 130.726 & $1,704,933,220$ & $3,549,315,366$ & 3.483 & $108.21 \%$ & 19,068 & 17,207 & $-9.76 \%$ & $3,524,304,064$ & $-34,488,698$ & $-.96 \%$ \\
\hline SOUTH & $1,412,086$ & $1,426,468$ & 1.028 & $29,382,009,210$ & $29,757,430,837$ & $23.14 \%$ & $1.28 \%$ & 21,010 & 20,98 & & & & \\
\hline
\end{tabular}




\subsection{Appendix B}

\section{Questionnaire}

\section{Dear Respondents}

I am conducting a study into the effect of shelf space positions on perceived Brand's Price and Quality. Kindly contribute by answering the Questions that follow as clearly as possible.

Thank you, The researcher 


\section{Section A:}

Suppose that you will visit one of the coop stores. You will find five different brands of apple Juice, with no description on them and no price tags on them either, kindly:

A.1- Specify the cell from which you prefer to choose the Juice, from the fine available brands placed on Vertically and Horizontally pangrams as follows:

\section{Veritcally:}

\begin{tabular}{|c|}
\hline Top 1 \\
\hline Top 2 \\
\hline Center \\
\hline Bottom 1 \\
\hline Bottom 2 \\
\hline
\end{tabular}

\section{Horizontally:}

\section{Bottom2}

\section{Bottom 1}

\section{Center}

Left

Left 1

A.2- Estimate each brand price from the following five response categories.

(1)2000 L.L (2) 2001-3099L.L (3) 4000 (4) 5999 L.L (5) 6000 (6)7999 L.L (5) 8000

L.L and more.

A.3- Please specify the degree to which you agree with the following states.

\section{A.3.1.Brands Positions preference:}

I prefer the following positions

\begin{tabular}{|c|c|c|c|c|c|}
\hline $\begin{array}{c}\text { Disagree } \\
\text { strongly }\end{array}$ & $\begin{array}{c}\text { Disagree } \\
\text { somewhat }\end{array}$ & $\begin{array}{c}\text { Neither } \\
\text { agree nor } \\
\text { disagree }\end{array}$ & $\begin{array}{c}\text { Agree } \\
\text { somewhat }\end{array}$ & $\begin{array}{c}\text { Agree } \\
\text { strongly }\end{array}$ & $\begin{array}{c}\text { 1-Vertical } \\
\text { Position }\end{array}$ \\
\hline & & & & & Top 1 \\
\hline & & & & & Top 2 \\
\hline & & & & & Center \\
\hline & & & & & Bottom 1 \\
\hline & & & & & Bottom 2 \\
\hline
\end{tabular}

\begin{tabular}{|c|c|c|c|c|c|}
\hline $\begin{array}{c}\text { Disagree } \\
\text { strongly }\end{array}$ & $\begin{array}{c}\text { Disagree } \\
\text { somewhat }\end{array}$ & $\begin{array}{c}\text { Neither } \\
\text { agree nor } \\
\text { disagree }\end{array}$ & $\begin{array}{c}\text { Agree } \\
\text { somewhat }\end{array}$ & $\begin{array}{c}\text { Agree } \\
\text { strongly }\end{array}$ & $\begin{array}{c}\text { 2-Horizontal } \\
\text { Position }\end{array}$ \\
\hline & & & & & Left 1 \\
\hline & & & & & Left 2 \\
\hline & & & & & Center \\
\hline & & & & & Right 1 \\
\hline & & & & & Right 2 \\
\hline
\end{tabular}


A.3.2.Brands perceived quality:

- Brands that are placed on the following positions have high quality.

\begin{tabular}{|c|c|c|c|c|c|}
\hline $\begin{array}{c}\text { Disagree } \\
\text { strongly }\end{array}$ & $\begin{array}{c}\text { Disagree } \\
\text { somewhat }\end{array}$ & $\begin{array}{c}\text { Neither } \\
\text { agree nor } \\
\text { disagree }\end{array}$ & $\begin{array}{c}\text { Agree } \\
\text { somewhat }\end{array}$ & $\begin{array}{c}\text { Agree } \\
\text { strongly }\end{array}$ & $\begin{array}{c}\text { 1-Vertical } \\
\text { Position }\end{array}$ \\
\hline & & & & & Top 1 \\
\hline & & & & & Top 2 \\
\hline & & & & & Center \\
\hline & & & & & Bottom 1 \\
\hline & & & & & Bottom 2 \\
\hline
\end{tabular}

\begin{tabular}{|c|c|c|c|c|c|}
\hline $\begin{array}{c}\text { Disagree } \\
\text { strongly }\end{array}$ & $\begin{array}{c}\text { Disagree } \\
\text { somewhat }\end{array}$ & $\begin{array}{c}\text { Neither } \\
\text { agree nor } \\
\text { disagree }\end{array}$ & $\begin{array}{c}\text { Agree } \\
\text { somewhat }\end{array}$ & $\begin{array}{c}\text { Agree } \\
\text { strongly }\end{array}$ & $\begin{array}{c}\text { 2- Horizontal } \\
\text { Position }\end{array}$ \\
\hline & & & & & Left 1 \\
\hline & & & & & Left 2 \\
\hline & & & & & Center \\
\hline & & & & & Right 1 \\
\hline & & & & & Right 2 \\
\hline
\end{tabular}

A.3.3.Brands perceived price:

Brands that are placed on the following positions have high price

\begin{tabular}{|c|c|c|c|c|c|}
\hline $\begin{array}{c}\text { Disagree } \\
\text { strongly }\end{array}$ & $\begin{array}{c}\text { Disagree } \\
\text { somewhat }\end{array}$ & $\begin{array}{c}\text { Neither } \\
\text { agree nor } \\
\text { disagree }\end{array}$ & $\begin{array}{c}\text { Agree } \\
\text { somewhat }\end{array}$ & $\begin{array}{c}\text { Agree } \\
\text { strongly }\end{array}$ & $\begin{array}{c}\text { 1-Vertical } \\
\text { Position }\end{array}$ \\
\hline & & & & & Top 1 \\
\hline & & & & & Top 2 \\
\hline & & & & & Center \\
\hline & & & & & Bottom 1 \\
\hline & & & & & Bottom 2 \\
\hline
\end{tabular}

\begin{tabular}{|c|c|c|c|c|c|}
\hline $\begin{array}{c}\text { Disagree } \\
\text { strongly }\end{array}$ & $\begin{array}{c}\text { Disagree } \\
\text { somewhat }\end{array}$ & $\begin{array}{c}\text { Neither } \\
\text { agree nor } \\
\text { disagree }\end{array}$ & $\begin{array}{c}\text { Agree } \\
\text { somewhat }\end{array}$ & $\begin{array}{c}\text { Agree } \\
\text { strongly }\end{array}$ & $\begin{array}{c}\text { 2-Horizontal } \\
\text { Position }\end{array}$ \\
\hline & & & & & Left 1 \\
\hline & & & & & Left 2 \\
\hline & & & & & Center \\
\hline & & & & & Right 1 \\
\hline
\end{tabular}




\section{Section B:}

B.1 Suppose the United company for Central markets "coop" built a new store, and there are eight brand with powder milk described using eight descriptions, the store has developed a pangram with 25 cells as follow:

\begin{tabular}{|c|c|c|c|c|}
\hline 5 & 4 & 3 & 2 & 1 \\
\hline 10 & 9 & 8 & 7 & 6 \\
\hline 15 & 14 & 13 & 12 & 11 \\
\hline 20 & 19 & 18 & 17 & 16 \\
\hline 25 & 24 & 23 & 22 & 21 \\
\hline
\end{tabular}

Kindly specify the right cell in which you will assign for the eight brands descriptions. Us the following table.

\begin{tabular}{|l|l|}
\hline Cell Number & \multicolumn{1}{c|}{ Brands' description } \\
\hline & 1- Price Leader \\
\hline & 2- Premium \\
\hline & 3- Promoted \\
\hline & 4- Popular \\
\hline & 5- Store \\
\hline & 6- Slow- moving \\
\hline & 7- Well- Known \\
\hline & 8- New \\
\hline
\end{tabular}

B.2. Kindly choose of (1) Ideal, $2^{\text {nd }}$ best and worst position from the 25 cells separately from each of the eight brands descriptions:

\begin{tabular}{|l|l|l|l|}
\hline Worst & \multicolumn{1}{|c|}{$\mathbf{2}^{\text {nd }}$ Best } & \multicolumn{1}{|c|}{ Ideal Position } & \multicolumn{1}{|c|}{ Brands' description } \\
\hline & & & 1- Price Leader \\
\hline & & & 2- Premium \\
\hline & & & 3- Promoted \\
\hline & & & 4- Popular \\
\hline & & & 5- Store \\
\hline & & & 6- Slow- moving \\
\hline & & & 7- Well- Known \\
\hline & & & 8- New \\
\hline & & &
\end{tabular}


B.3.Kindly specify the degree to which you prefer each of the 25 cells for the placement of one or more of the eight brands.

Key: Select 5 for strongly prefer, 4 for prefer, 3 for neutral, 2 for do not prefer, 1 for strongly do not prefer.

\begin{tabular}{|c|c|c|c|c|c|c|c|c|c|c|c|c|c|c|c|c|c|c|c|c|c|c|c|c|c|}
\hline \multicolumn{25}{|c|}{ Cells } & \multirow{2}{*}{ Brand Categories } \\
\hline 25 & 24 & 23 & 22 & 21 & 20 & 19 & 18 & 17 & 16 & 15 & 14 & 13 & 12 & 11 & 10 & 9 & 8 & 7 & 6 & 5 & 4 & 3 & 2 & 1 & \\
\hline & & & & & & & & & & & & & & & & & & & & & & & & & 1- Price Leader \\
\hline & & & & & & & & & & & & & & & & & & & & & & & & & 2- Premium \\
\hline & & & & & & & & & & & & & & & & & & & & & & & & & 3- Promoted \\
\hline & & & & & & & & & & & & & & & & & & & & & & & & & 4- Popular \\
\hline & & & & & & & & & & & & & & & & & & & & & & & & & 5- Store \\
\hline & & & & & & & & & & & & & & & & & & & & & & & & & 6- Slow- moving \\
\hline & & & & & & & & & & & & & & & & & & & & & & & & & 7- Well- Known \\
\hline & & & & & & & & & & & & & & & & & & & & & & & & & 8- New \\
\hline
\end{tabular}




\subsection{Appendix $C$ \\ The results of hypotheses test}

1.The results of the ANOVA test for H. 1

Table 1: The results of the ANOVA tests.

Customers preference of Vertical shelf space positions

\begin{tabular}{|c|c|c|c|c|c|c|c|}
\hline P- Value & F- Value & Bottom 2 & Bottom 1 & Center & Top 2 & Top 1 & $\begin{array}{c}\text { Vertical } \\
\text { Positions }\end{array}$ \\
\hline 0,000 & 2642,58 & 1,6094 & 1,6715 & 3,0313 & 4,2786 & 4,4635 & Mean \\
& 0,5196 & 0,5177 & 0,5177 & 0,4560 & 0,5190 & 0,5298 & St. Dev \\
\hline
\end{tabular}

Table 2: The results of the ANOVA tests

Operations \& commercial department managers' preference of Vertical shelf space positions

\begin{tabular}{|c|c|c|c|c|c|c|c|}
\hline P- Value & F- Value & Bottom 2 & Bottom 1 & Center & Top 2 & Top 1 & $\begin{array}{c}\text { Vertical } \\
\text { Positions }\end{array}$ \\
\hline 0,000 & 372,66 & 1,5366 & 1,7317 & 3,0244 & 4,3171 & 4,4878 & Mean \\
& & 0,5049 & 0,4486 & 0,2727 & 0,5215 & 0,5061 & St.Dev \\
\hline
\end{tabular}

Table 3: The results of the ANOVA tests

Store managers' preferences of Vertical shelf space positions

\begin{tabular}{|c|c|c|c|c|c|c|c|}
\hline P- Value & \multirow{2}{*}{ F- Value } & Bottom 2 & Bottom 1 & Center & Top 2 & Top 1 & $\begin{array}{c}\text { Vertical } \\
\text { Positions }\end{array}$ \\
\hline \multirow{2}{*}{0,000} & \multirow{2}{*}{459,59} & 1,7059 & 1,6863 & 2,9216 & 4,3137 & 4,4902 & $\begin{array}{c}\text { Mean } \\
\end{array}$ \\
\hline
\end{tabular}

2.The results of the ANOVA test for $H .2$

Table 4: The results of the ANOVA Tests

Vertical shelf space positions' preferences

\begin{tabular}{|c|c|c|c|c|}
\hline P-Value & F- Value & St.Dev & Mean & Vertical Positions \\
\hline 0,915 & 0,09 & $\begin{array}{l}0,5298 \\
0,5061 \\
0,5049\end{array}$ & $\begin{array}{l}4,4635 \\
4,4878 \\
4,4902\end{array}$ & $\begin{array}{l}\text { Top 1 } \\
\text { - Customers } \\
\text { - Operations \&Commercial department Managers } \\
\text { - Store managers }\end{array}$ \\
\hline 0,831 & 0,19 & $\begin{array}{l}0,5190 \\
0,5215 \\
0,5095\end{array}$ & $\begin{array}{l}4,2786 \\
4,3171 \\
4,3137\end{array}$ & $\begin{array}{l}\text { Top 2 } \\
\text { - Customers } \\
\text { - Operations \&Commercial department Managers } \\
\text { - Store managers }\end{array}$ \\
\hline 0,227 & 1,49 & $\begin{array}{l}0,4560 \\
0,2727 \\
0,2715\end{array}$ & $\begin{array}{l}3,0313 \\
3,0244 \\
2,9216\end{array}$ & $\begin{array}{l}\text { Central } \\
\text { - Customers } \\
\text { - Operations \& Commercial department managers } \\
\text { - Store managers }\end{array}$ \\
\hline 0,768 & 0,26 & $\begin{array}{l}0,5177 \\
0,4486 \\
0,4686\end{array}$ & $\begin{array}{l}1,6719 \\
1,7317 \\
1,6867\end{array}$ & $\begin{array}{l}\text { - Customers } \\
\text { - Operations \& commercial department managers } \\
\text { - Store managers }\end{array}$ \\
\hline 0,273 & 1,30 & $\begin{array}{l}0,5196 \\
0,5049 \\
0,4602\end{array}$ & $\begin{array}{l}1,6094 \\
1,5366 \\
1,7059\end{array}$ & $\begin{array}{l}\text { Bottom 2 } \\
\text { - Customers } \\
\text { - Operations \& Commercial department managers } \\
\text { - Store managers }\end{array}$ \\
\hline
\end{tabular}




\section{The results of the ANOVA test for $\mathrm{H} .3$}

Table 5: The results of the AVONA tests.

Customers perceived price for different shelf space positions

\begin{tabular}{|c|c|c|c|c|c|c|c|}
\hline P- Value & F- Value & Bottom 2 & Bottom 1 & Center & Top 2 & Top 1 & $\begin{array}{c}\text { Vertical } \\
\text { Positions }\end{array}$ \\
\hline 0,000 & 277,58 & 1,6466 & 1,6589 & 2,9479 & 4,2969 & 4,3828 & Mean \\
& & 0,4858 & 0,4802 & 0,4540 & 0,5450 & 0,5328 & St.Dev \\
\hline
\end{tabular}

Table 6: The results of the AVONA tests.

Operations \& Commercial department managers' perceived Price for different Vertical shelf space positions

\begin{tabular}{|c|c|c|c|c|c|c|c|}
\hline P- Value & F- Value & Bottom 2 & Bottom 1 & Central & Top 2 & Top 1 & $\begin{array}{c}\text { Vertical } \\
\text { Positions }\end{array}$ \\
\hline 0,000 & 399,46 & 1,6585 & 1,5616 & 2,924 & 4,5366 & 4,4878 & Mean \\
& 0,4801 & 0,5024 & 0,3004 & 0,5049 & 0,5061 & St.Dev \\
\hline
\end{tabular}

Table 7: The results of the AVONA tests.

Store managers' perceived price for different Vertical shelf Space positions

\begin{tabular}{|c|c|c|c|c|c|c|c|}
\hline P- Value & F- Value & Bottom 2 & Bottom 1 & Center & Top 2 & Top 1 & $\begin{array}{c}\text { Vertical } \\
\text { Positions }\end{array}$ \\
\hline & & 1,7059 & 1,6863 & 2,9216 & 4,3137 & 4,4902 & Mean \\
0,000 & 459,59 & 0,4602 & 0,4686 & 0,2715 & 0,5095 & 0,549 & St.Dev \\
\hline
\end{tabular}

\section{The results of the ANOVA test for $\mathrm{H} .4$}

Table 8: The results of the ANOVA Tests

Vertical shelf space Perceived prices

\begin{tabular}{|c|c|c|c|c|}
\hline P-Value & F- Value & St. Dev & Mean & Vertical Positions perceived price \\
\hline 0,223 & 1,51 & $\begin{array}{l}0,5328 \\
0,5061 \\
0,5049\end{array}$ & $\begin{array}{l}4,3828 \\
4,4878 \\
4,4902\end{array}$ & $\begin{array}{l}\text { Top 1 } \\
\text { - Customers } \\
\text { - Operations \& Commercial department Managers } \\
\text { - Store managers }\end{array}$ \\
\hline 0,026 & 3,67 & $\begin{array}{l}0,5495 \\
0,5049 \\
0,5095\end{array}$ & $\begin{array}{l}4,2969 \\
4,5366 \\
4,3137\end{array}$ & $\begin{array}{l}\text { Top 2 } \\
\text { - Customers } \\
\text { - Operations \& Commercial department Managers } \\
\text { - Store managers }\end{array}$ \\
\hline 0,765 & 0,27 & $\begin{array}{l}0,4540 \\
0,3004 \\
0,2715\end{array}$ & $\begin{array}{l}2,9479 \\
2,9024 \\
2,9216\end{array}$ & $\begin{array}{l}\text { - Central customers } \\
\text { - Operations \& Commercial department Managers } \\
\text { - Store managers }\end{array}$ \\
\hline 0,407 & 0,90 & $\begin{array}{l}0.4802 \\
0.5024 \\
0.4686\end{array}$ & $\begin{array}{l}1,6589 \\
1,5616 \\
1,6863\end{array}$ & $\begin{array}{l}\text { Bottom1 } \\
\text { - Customers } \\
\text { - Operations \& Commercial department Managers } \\
\text { - Store managers }\end{array}$ \\
\hline 0,657 & 0,42 & $\begin{array}{l}0,4858 \\
0,4801 \\
0,4602\end{array}$ & $\begin{array}{c}1,6406 \\
1,65851, \\
7059\end{array}$ & $\begin{array}{l}\text { - Customers } \quad \text { Bottom 2 } \\
\text { - Operations \& Commercial department Managers } \\
\text { - Store managers }\end{array}$ \\
\hline
\end{tabular}


5.The results of the ANOVA test for $\mathrm{H} .5$

Table 9: The results of the ANOVA Tests

Customers perceived quality for $\mathbf{H} .5$

\begin{tabular}{|c|c|c|c|c|c|c|c|}
\hline P- Value & F- Value & Bottom 2 & Bottom 1 & Central & Top 2 & Top 1 & $\begin{array}{c}\text { Vertical } \\
\text { Positions }\end{array}$ \\
\hline \multirow{2}{*}{0,000} & \multirow{2}{*}{1071,20} & 2,0391 & 2,0365 & 4,3880 & 3,9505 & 3,9583 & Mean \\
& & 0,6901 & 0,6959 & 0,5190 & 0,7511 & 0,7393 & St.Dev \\
\hline
\end{tabular}

Table 10: The results of the ANOVA Tests

Operation \& Commercial department managers'

Perceived quality

\begin{tabular}{|c|c|c|c|c|c|c|c|}
\hline P- Value & F- Value & Bottom 2 & Bottom 1 & Center & Top 2 & Top 1 & $\begin{array}{c}\text { Vertical } \\
\text { Positions }\end{array}$ \\
\hline & & 2,0732 & 1,9756 & 4,3415 & 4,0244 & 3,9756 & Mean \\
& & 0,7208 & 0,6888 & 0,4801 & 0,7241 & 0,7241 & St.Dev \\
\hline
\end{tabular}

Table 11: The results of the ANOVA Tests

Store managers' perceived Quality

\begin{tabular}{|c|c|c|c|c|c|c|c|}
\hline P- Value & F- Value & Bottom 2 & Bottom 1 & Center & Top 2 & Top 1 & $\begin{array}{c}\text { Vertical } \\
\text { Positions }\end{array}$ \\
\hline & & 1,7059 & 1,6863 & 2,5216 & 4,3137 & 4,4092 & Mean \\
& & 0,4602 & 0,4686 & 0,2715 & 0,5095 & 0,5049 & St.Dev \\
\hline
\end{tabular}

6. The results of the ANOVA test for H. 6

Table 12: The results of the ANOVA tests Vertical shelf space positions perceived quality

\begin{tabular}{|c|c|c|c|c|}
\hline P-Value & F- Value & St. Dev & Mean & Vertical Positions \\
\hline 0.000 & 12,47 & $\begin{array}{l}0,7393 \\
0,7241 \\
0,5645\end{array}$ & $\begin{array}{l}3,9586 \\
3,9756 \\
4,4902\end{array}$ & $\begin{array}{l}\text { Top 1 } \\
\text { - Customers } \\
\text { - Operations \&Commercial department Managers } \\
\text { - Store managers }\end{array}$ \\
\hline 0,004 & 5,65 & $\begin{array}{l}0,7511 \\
0,7241 \\
0,5095\end{array}$ & $\begin{array}{l}3,9505 \\
4,0249 \\
4,3137\end{array}$ & $\begin{array}{l}\text { - Customers } \\
\text { - Top 2 } \\
\text { - Operations \&Commercial department Managers } \\
\text { - Store managers }\end{array}$ \\
\hline 0,000 & 198,43 & $\begin{array}{l}0,5190 \\
0,4801 \\
0,2715\end{array}$ & $\begin{array}{l}4,3880 \\
4,3415 \\
2,9216\end{array}$ & $\begin{array}{l}\text { - Customers } \\
\text { - Operations \&Commercial department Managers } \\
\text { - Store managers }\end{array}$ \\
\hline 0,002 & 6,08 & $\begin{array}{l}0,6959 \\
0,6888 \\
0,4686\end{array}$ & $\begin{array}{l}2,0365 \\
1,9756 \\
1,6863\end{array}$ & $\begin{array}{l}\text { - Customers } \\
\text { - Bottom 1: } \\
\text { - Operations \&Commercial department Managers } \\
\text { - Store managers }\end{array}$ \\
\hline 0,003 & 5,75 & $\begin{array}{l}0,6901 \\
0,7208 \\
0,4602\end{array}$ & $\begin{array}{l}2,0391 \\
2,0732 \\
1,7059\end{array}$ & $\begin{array}{l}\text { - Bottom 2: } \\
\text { - Customers } \\
\text { - Operations \&Commercial department Managers } \\
\text { - Store managers }\end{array}$ \\
\hline
\end{tabular}




\section{The results of the ANOVA test for $\mathrm{H}: 7$}

Table 13: The results of the ANOVA test

Customers preferences of the Horizontal shelf space positions

\begin{tabular}{|c|c|c|c|c|c|c|c|}
\hline P-value & F-value & Left 2 & Left 1 & Central & Right 2 & Right 1 & $\begin{array}{c}\text { Horizontal } \\
\text { Positions }\end{array}$ \\
\hline \multirow{2}{*}{$\mathbf{0 0 0 0}$} & \multirow{2}{*}{$\mathbf{3 2 3 3 , 0 7}$} & 1,6563 & 1,6979 & 2,8984 & 4,3411 & 4,4375 & Mean \\
& 0,4756 & 0,4873 & 0,3578 & 0,4962 & 0,5071 & St.Dev \\
\hline
\end{tabular}

Table 14: The results of the ANOVA test

Operations \& commercial department managers' preferences of the Horizontal shelf space positions

\begin{tabular}{|c|c|c|c|c|c|c|c|}
\hline P- Value & F-Value & Left 2 & Left 1 & Center & Right 2 & Right 1 & $\begin{array}{c}\text { Horizontal } \\
\text { Positions }\end{array}$ \\
\hline & & 1,6341 & 1,5854 & 2,9268 & 4,4390 & 4,4634 & Mean \\
0.000 & 389.60 & 0,4877 & 0,4988 & 0,2637 & 0,5024 & 0,5049 & St.Dev \\
\hline
\end{tabular}

Table 15: The results of the ANOVA Test

Store managers' preferences of the Horizontal shelf space positions

\begin{tabular}{|c|c|c|c|c|c|c|c|}
\hline P- Value & F-Value & Left 2 & Left 1 & Center & Right 2 & Right 1 & $\begin{array}{c}\text { Horizonta } \\
\text { Positions }\end{array}$ \\
\hline 0.000 & 443,28 & $\begin{array}{l}1,6471 \\
0,4826\end{array}$ & $\begin{array}{l}1,6078 \\
0,5321\end{array}$ & $\begin{array}{l}2,8235 \\
0,3850\end{array}$ & $\begin{array}{l}4,3922 \\
0,4931\end{array}$ & $\begin{array}{l}4,5294 \\
0,5041\end{array}$ & $\begin{array}{c}\text { Mean } \\
\text { St. Dev }\end{array}$ \\
\hline
\end{tabular}

8.The results of the ANOVA test for H. 8

Table 16: The results of the ANOVA

Horizontal shelf space positions

\begin{tabular}{|c|c|c|c|c|}
\hline P- Value & F-Value & St. Dev & Mean & Horizontal Positions \\
\hline 0,479 & 0,74 & $\begin{array}{l}0,5073 \\
0,5049 \\
0,5041\end{array}$ & $\begin{array}{l}4,4386 \\
4,4634 \\
4,5294\end{array}$ & $\begin{array}{l}\text { Right 1 } \\
\text { - Customers } \\
\text { - Operations \& Commercial department Managers } \\
\text { - Store managers }\end{array}$ \\
\hline 0,400 & 0,92 & $\begin{array}{l}0,4957 \\
0,5024 \\
0,4931\end{array}$ & $\begin{array}{l}4,3394 \\
4,4390 \\
4,3922\end{array}$ & $\begin{array}{l}\text { Right } 2 \\
\text { - Customers } \\
\text { - Operations \& Commercial department Managers } \\
\text { - Store managers }\end{array}$ \\
\hline 0,300 & 1,21 & $\begin{array}{l}0,3583 \\
0,2637 \\
0,3850\end{array}$ & $\begin{array}{l}2,8982 \\
2,9268 \\
2,8239\end{array}$ & $\begin{array}{l}\text { Center } \\
\text { - Customers } \\
\text { - Operations \& Commercial department Managers } \\
\text { - Store managers }\end{array}$ \\
\hline 0,215 & 1,53 & $\begin{array}{l}0,4877 \\
0,4988 \\
0,5321\end{array}$ & $\begin{array}{l}1,6971 \\
1,5854 \\
1,6078\end{array}$ & $\begin{array}{l}\text { Left } 1 \\
\text { - Customers } \\
\text { - Operations \& Commercial department Managers } \\
\text { - Store managers }\end{array}$ \\
\hline 0,948 & 0,05 & $\begin{array}{l}0,4750 \\
0,4877 \\
0,4826\end{array}$ & $\begin{array}{l}1,6580 \\
1,6341 \\
1,6471\end{array}$ & $\begin{array}{l}\text { - Customers } \\
\text { - Operations \& Commercial department Managers } \\
\text { - Store managers }\end{array}$ \\
\hline
\end{tabular}




\section{The results of the ANOVA test For H. 9}

Table 17: The results of the ANOVA Test

Customers perceived Price for the different Horizontal shelf space positions

\begin{tabular}{|c|c|c|c|c|c|c|c|}
\hline P- Value & F-Value & Left 2 & Left 1 & Center & Right 2 & Right 1 & $\begin{array}{c}\text { Horizontal } \\
\text { Positions }\end{array}$ \\
\hline 0.000 & 137,78 & 1,5512 & 2,000 & 4,4878 & 4,1220 & 4,000 & Mean \\
& & 0,6690 & 0,707 & 0,5061 & 0,7482 & 07071 & St.Dev \\
\hline
\end{tabular}

Table 18: The results of the ANOVA Test

Operations \& commercial department mangers' perceived price for different Horizontal shelf space positions

\begin{tabular}{|c|c|c|c|c|c|c|c|}
\hline P- Value & F-Value & Left 2 & Left 1 & Center & Right 2 & Right 1 & $\begin{array}{c}\text { Horizontal } \\
\text { Positions }\end{array}$ \\
\hline 0.000 & 2544,6 & 1,7500 & 1,7266 & 2,9089 & 4,4010 & 4,3464 & Mean \\
& & 0,5503 & 0,5604 & 0,4017 & 0,5167 & 0,5184 & St. Dev \\
\hline
\end{tabular}

Table 19: The results of the ANOVA Test Store managers' perceived price for different Horizontal Shelf space positions

\begin{tabular}{|c|c|c|c|c|c|c|c|}
\hline P- Value & F-Value & Left 2 & Left 1 & Center & Right 2 & Right 1 & $\begin{array}{c}\text { Horizontal } \\
\text { Positions }\end{array}$ \\
\hline 0,000 & 311,39 & 1,7451 & 1,7255 & 2,9216 & 4,3922 & 4,5294 & Mean \\
& & 0,5947 & 0,6026 & 0,5601 & 0,4931 & 0,5041 & St.Dev \\
\hline
\end{tabular}

10. the results of the $\triangle$ NOVA Test for $\mathrm{H}: 10$

Table 20: The results of the ANOVA Test

Horizontal shelf space perceived price

\begin{tabular}{|c|c|c|c|c|}
\hline P- Value & F- Value & St. Dev & Mean & Horizontal Positions \\
\hline 0,000 & 11,47 & $\begin{array}{l}0,5184 \\
0,7071 \\
0,5041\end{array}$ & $\begin{array}{l}4,3464 \\
4,000 \\
4,5294\end{array}$ & $\begin{array}{l}\text { Right } 1 \\
\text { - Customers } \\
\text { - Operations \&Commercial department Managers } \\
\text { - Store managers }\end{array}$ \\
\hline 0,007 & 5,01 & $\begin{array}{l}0,5167 \\
0,7482 \\
0,4931\end{array}$ & $\begin{array}{l}4,4010 \\
4,1220 \\
4,3922\end{array}$ & $\begin{array}{l}\text { - Customers } \\
\text { Right } 2 \\
\text { - Operations \&Commercial department Managers } \\
\text { - Store managers }\end{array}$ \\
\hline 0,000 & 251,33 & $\begin{array}{l}0,4017 \\
0,5061 \\
0,5601\end{array}$ & $\begin{array}{l}2,9089 \\
4,4878 \\
2,9216\end{array}$ & $\begin{array}{l}\text { Center } \\
\text { - Customers } \\
\text { - Operations \&Commercial department Managers } \\
\text { - Store managers }\end{array}$ \\
\hline 0,16 & 4,19 & $\begin{array}{l}0,5604 \\
0,7071 \\
0,6026\end{array}$ & $\begin{array}{c}1,7266 \\
2,000 \\
1,7255\end{array}$ & $\begin{array}{l}\text { - Customers } \\
\text { - Operations \&Commercial department Managers } \\
\text { - Store managers }\end{array}$ \\
\hline 0,093 & 2,38 & $\begin{array}{l}0,5503 \\
0,6690 \\
0,5947\end{array}$ & $\begin{array}{c}1,75000 \\
1,9512 \\
1,7451\end{array}$ & $\begin{array}{l}\text { Left } 2 \\
\text { - Customers } \\
\text { - Operations \&Commercial department Managers } \\
\text { - Store managers }\end{array}$ \\
\hline
\end{tabular}




\section{1 .The results of the ANOVA test for H.11}

Table 21: The results of the ANOVA test.

Customers perceived quality of the products that are placed on different Horizontal shelf space positions

\begin{tabular}{|c|c|c|c|c|c|c|c|}
\hline P- Value & F- Value & Left 2 & Left 1 & Center & Right 2 & Right 1 & $\begin{array}{c}\text { Horizontal } \\
\text { Positions }\end{array}$ \\
\hline 0,000 & 1006,7 & 2,0599 & 2,0147 & 4,3854 & 3,9661 & 3,9427 & Mean \\
& & 0,7256 & 0,6994 & 0,5573 & 0,7379 & 0,7660 & St. Dev \\
\hline
\end{tabular}

Table 22: The results of the ANOVA Test

Operations \& commercial department managers' perceived quality of the products that are placed on different Horizontal shelf space positions

\begin{tabular}{|c|c|c|c|c|c|c|c|}
\hline P- Value & F- Value & Left 2 & Left 1 & Center & Right 2 & Right 1 & $\begin{array}{c}\text { Horizontal } \\
\text { Positions }\end{array}$ \\
\hline \multirow{2}{*}{0,000} & \multirow{2}{*}{118,85} & 2,000 & 2,000 & 4,61634 & 3,9024 & 3,8537 & Mean \\
& & 0,6708 & 0,7071 & 0,5049 & 0,7350 & 0,7603 & St. Dev \\
\hline
\end{tabular}

Table 23: The results of the ANOVA Test Store managers' perceived quality of the products that are placed on different Horizontal shelf space positions

\begin{tabular}{|c|c|c|c|c|c|c|c|}
\hline P- Value & F- Value & Left 2 & Left 1 & Center & Right 2 & Right 1 & $\begin{array}{c}\text { Horizontal } \\
\text { Positions }\end{array}$ \\
\hline \multirow{2}{*}{0.0000} & 219,53 & 1,8235 & 1,8639 & 2,7647 & 4,3922 & 4,5294 & Mean \\
& & 0,6843 & 0,7217 & 0,7639 & 0,4931 & 0,5041 & St.Dev \\
\hline
\end{tabular}

12. the results of the $\triangle$ NOVA test for $H .11$

Table 24: The results of the AVONA tests.

Horizontal shelf space perceived quality

\begin{tabular}{|c|c|c|c|c|}
\hline P- Value & F- Value & St.Dev & Mean & Horizontal Positions \\
\hline 0,000 & 14,91 & $\begin{array}{l}0,7660 \\
0,7603 \\
6,5641\end{array}$ & $\begin{array}{l}3,9427 \\
3,8537 \\
4,5294\end{array}$ & $\begin{array}{l}\text { Right } 1 \\
\text { - Customers } \\
\text { - Operations \& commercial department Managers } \\
\text { - Store managers }\end{array}$ \\
\hline 0,000 & 8,45 & $\begin{array}{l}0,7379 \\
0,7350 \\
0,4931\end{array}$ & $\begin{array}{l}3,9661 \\
3,9024 \\
4,3922\end{array}$ & $\begin{array}{l}\text { Right } 2 \\
\text { - Customers } \\
\text { - Operations \& commercial department Managers } \\
\text { - Store managers }\end{array}$ \\
\hline 0,000 & 180,66 & $\begin{array}{l}0,5573 \\
0,5049 \\
0,7639\end{array}$ & $\begin{array}{l}4,3854 \\
4,4634 \\
2,7647\end{array}$ & $\begin{array}{l}\text { Center } \\
\text { - Customers } \\
\text { - Operations \& commercial department Managers } \\
\text { - Store managers }\end{array}$ \\
\hline 0,076 & 2,29 & $\begin{array}{l}0,6994 \\
0,7071 \\
0,7217\end{array}$ & $\begin{array}{c}3,0417 \\
2,000 \\
1,8039\end{array}$ & $\begin{array}{l}\text { Left } 1 \\
\text { - Customers } \\
\text { - Operations \& commercial department Managers } \\
\text { - Store managers }\end{array}$ \\
\hline 0,084 & 2,49 & $\begin{array}{l}0,7256 \\
0,6708 \\
0,6843\end{array}$ & $\begin{array}{c}2,0595 \\
2,000 \\
1,8235\end{array}$ & $\begin{array}{l}\text { Left } 2 \\
\text { - Customers } \\
\text { - Operations \& commercial department Managers } \\
\text { - Store managers }\end{array}$ \\
\hline
\end{tabular}




\section{3.the Results of the tests for $H .12$}

13.1 Placement choices by brand as a percentage of frequencies of these choices

Table 25: Placement choices for a brand among 25 positions

\begin{tabular}{|c|c|c|c|c|c|c|c|c|c|}
\hline \multicolumn{3}{|c|}{$\begin{array}{c}\text { Operations \& Commercial } \\
\text { department managers }\end{array}$} & \multicolumn{3}{|c|}{ Store Managers } & \multicolumn{3}{|c|}{ Customers } & \multirow[b]{2}{*}{ Brands } \\
\hline Worst & $2^{\text {nd }}$ Best & Ideal & Worst & $2^{\text {nd }}$ Best & Ideal & Worst & $2^{\text {nd }}$ Best & Ideal & \\
\hline $25(24 \%)$ & $16(31 \%)$ & $18(36,6 \%)$ & $3(23,5 \%)$ & $11(17,6 \%)$ & $23(25,5 \%)$ & $3(15,6 \%)$ & $10(14,3 \%)$ & $12(13,3 \%)$ & - Cheapest \\
\hline $\mathrm{B}_{2 .} \cdot \mathrm{L}_{2}$ & $\mathrm{~B}_{1} \cdot \mathrm{R}_{1}$ & $\mathrm{~B}_{1} . \mathrm{C}$ & $\mathrm{T}_{1} . \mathrm{C}$ & C. $\mathrm{R}_{1}$ & $\mathrm{~B}_{2} . \mathrm{C}$ & $\mathrm{T}_{1} . \mathrm{C}$ & $\mathrm{T}_{2} \cdot \mathrm{L}_{2}$ & C. $\mathrm{R}_{2}$ & \\
\hline $10(29 \%)$ & $23(29 \%)$ & $16(31 \%)$ & $22(27,5 \%)$ & $2(17,6 \%)$ & $13(25,5 \%)$ & $22(12 \%)$ & $3(17,4 \%)$ & $8(19,8 \%)$ & - Premium \\
\hline $\mathrm{T}_{2 .} \mathrm{L}_{2}$ & $\mathrm{~B}_{2} . \mathrm{C}$ & $\mathrm{B}_{1} \cdot \mathrm{R}_{1}$ & $\mathrm{~B}_{2} \cdot \mathrm{R}_{2}$ & $\mathrm{~T}_{1} \cdot \mathrm{R}_{2}$ & C.C & $\mathrm{B}_{2 .} \mathrm{R}_{2}$ & $\mathrm{~T}_{1} . \mathrm{C}$ & $\mathrm{T}_{2} . \mathrm{C}$ & \\
\hline $1(19 \%)$ & $18(19 \%)$ & $20(26 \%)$ & $10(17,6 \%)$ & $2(17,6 \%)$ & $8(25,5 \%)$ & $17(9,9 \%)$ & $1(14,6 \%)$ & $13(14,8 \%)$ & - Popular \\
\hline $\mathrm{T}_{1} . \mathrm{R}_{1}$ & $\mathrm{~B}_{1} . \mathrm{C}$ & $\mathrm{B}_{1} . \mathrm{L}_{2}$ & $\mathrm{~T}_{2 .} \mathrm{L}_{2}$ & $\mathrm{~T}_{1} \mathrm{R}_{2}$ & $\mathrm{~T}_{2} . \mathrm{C}$ & $\mathrm{B}_{2 .} \mathrm{R}_{2}$ & $\mathrm{~T}_{1} \mathrm{R}_{1}$ & C.C & \\
\hline $5(41 \%)$ & $23(29,3 \%)$ & $16(26,6 \%)$ & $2(15,7 \%)$ & $14(23.3 \%)$ & $8(25,5 \%)$ & $6(10,7 \%)$ & $13(11,7 \%)$ & $9(11,7 \%)$ & - Promoted \\
\hline $\mathrm{T}_{1} . \mathrm{L}_{2}$ & $\mathrm{~B}_{2} \cdot \mathrm{R}_{2}$ & $\mathrm{~B}_{1} \cdot \mathrm{R}_{1}$ & $\mathrm{~T}_{1} \cdot \mathrm{R}_{2}$ & C. $\mathrm{L}_{1}$ & $\mathrm{~T}_{2} . \mathrm{C}$ & $\mathrm{T}_{2} \cdot \mathrm{R}_{1}$ & C.C & $\mathrm{T}_{2} \mathrm{~L}_{1}$ & \\
\hline $2(34.1 \%)$ & $15(24.4 \%)$ & $18(31 \%)$ & $1(29.4 \%)$ & $23(19.6 \%)$ & $20(27.5 \%)$ & $1(19,3 \%)$ & $9(11,5 \%)$ & $14(10,9 \%)$ & - Store \\
\hline $\mathrm{T}_{1} . \mathrm{R}_{2}$ & C. $\mathrm{L}_{2}$ & $\mathrm{~B}_{1} . \mathrm{C}$ & $\mathrm{T}_{1} \cdot \mathrm{R}_{1}$ & $\mathrm{~B}_{2} . \mathrm{C}$ & $\mathrm{B}_{1} . \mathrm{L}_{2}$ & $\mathrm{~T}_{1} \cdot \mathrm{R}_{1}$ & $\mathrm{~T}_{2} \cdot \mathrm{L}_{1}$ & C. $\mathrm{L}_{1}$ & \\
\hline $7(26.8 \%)$ & $5(41 \%)$ & $18(39 \%)$ & $2(19.6 \%)$ & $25(16.7 \%)$ & $13(27.5 \%)$ & $11(11.5 \%)$ & $25(14.6 \%)$ & $4(15.6 \%)$ & - Well- Known \\
\hline $\mathrm{T}_{2} \cdot \mathrm{R}_{2}$ & $\mathrm{~T}_{1} . \mathrm{L} 2$ & $\mathrm{~B}_{1} . \mathrm{C}$ & $\mathrm{T}_{1} \cdot \mathrm{R}_{2}$ & $\mathrm{~B}_{2 .} \mathrm{L}_{2}$ & C.C & C. $\mathrm{R}_{1}$ & $\mathrm{~B}_{2 .} \mathrm{L}_{2}$ & $\mathrm{~T}_{1} . \mathrm{L}_{1}$ & \\
\hline $7(26.8)$ & $18(26.8 \%)$ & $3(39 \%)$ & $12(21.6 \%)$ & $25(31.4 \%)$ & $5(25.5 \%)$ & $19(18.8 \%)$ & $15(18.2 \%)$ & $8(20.6 \%)$ & - New \\
\hline $\mathrm{T}_{2} \cdot \mathrm{R}_{2}$ & $\mathrm{~B}_{1} . \mathrm{C}$ & $\mathrm{T}_{1} . \mathrm{C}$ & C. $\mathrm{R}_{2}$ & $\mathrm{~B}_{2} \cdot \mathrm{L}_{2}$ & $\mathrm{~T}_{1} . \mathrm{L}_{1}$ & $\mathrm{~B}_{1} . \mathrm{L}_{1}$ & $\mathrm{~B}_{2 .} \mathrm{L}_{2}$ & $\mathrm{~T}_{2} . \mathrm{C}$ & \\
\hline $3(36 \%)$ & $19(26 \%)$ & $18(22 \%)$ & $15(62.7 \%)$ & $22(29.4 \%)$ & $8(25.5 \%)$ & $10(14.8 \%)$ & $5(16.4 \%)$ & $18(15.6 \%)$ & - Show moving \\
\hline $\mathrm{T}_{1} . \mathrm{C}$ & $\mathrm{B}_{1 . \mathrm{L} 1}$ & $\mathrm{~B}_{1} . \mathrm{C}$ & C. $\mathrm{L}_{2}$ & $\mathrm{~B}_{2} . \mathrm{R}_{2}$ & $\mathrm{~T}_{2} \cdot \mathrm{C}$ & $\mathrm{T}_{2} . \mathrm{L}_{2}$ & $\mathrm{~T}_{1} . \mathrm{L}_{2}$ & $\mathrm{~B}_{1} . \mathrm{C}$ & \\
\hline
\end{tabular}

Right 1: R1 Top $1=\mathrm{T} 1$

Right 2: R2 Top 2= T2

Center $=\mathrm{C} \quad$ Bottom $1=\mathrm{B} 1$

Left $1=\mathrm{L} 1 \quad$ Bottom $2=\mathrm{B} 2$

Left $2=\mathrm{L} 2$ 
13.2 comparison among the three groups of respondents with regard to the 1 ideal, $2^{\text {nd }}$ best and worst position for the eight brands

Table 26: Comparison among customers

Operations \& Commercial department managers and store managers

with regard to the ideal, $2^{\text {nd }}$ best and the worst positions for each brand in the brand category

\begin{tabular}{|c|c|c|c|c|c|c|c|c|c|}
\hline \multicolumn{3}{|c|}{ Worst } & \multicolumn{3}{|c|}{$2^{\text {nd }}$ Best } & \multicolumn{3}{|c|}{ Ideal } & \multirow[b]{2}{*}{ Brand } \\
\hline $\begin{array}{c}\text { Operations \& } \\
\text { Commercial } \\
\text { department Managers }\end{array}$ & $\begin{array}{c}\text { Store } \\
\text { managers }\end{array}$ & Customers & $\begin{array}{c}\text { Operations \& } \\
\text { Commercial } \\
\text { department } \\
\text { Managers } \\
\end{array}$ & $\begin{array}{c}\text { Store } \\
\text { managers }\end{array}$ & Customers & $\begin{array}{c}\text { Operations \& } \\
\text { Commercial } \\
\text { department } \\
\text { Managers }\end{array}$ & $\begin{array}{c}\text { Store } \\
\text { managers }\end{array}$ & Customers & \\
\hline $\begin{array}{c}21 \\
\mathrm{~B}_{2} . \mathrm{L}_{1} \\
\end{array}$ & $\begin{array}{c}21 \\
\mathrm{~B}_{2} . \mathrm{L}_{1} \\
\end{array}$ & $\begin{array}{c}25 \\
\mathrm{R}_{2} \cdot \mathrm{B}_{2} \\
\end{array}$ & $\begin{array}{c}13 \\
\text { C.C } \\
\end{array}$ & $\begin{array}{c}22 \\
\mathrm{~L}_{2} \mathrm{~B}_{2} \\
\end{array}$ & $\begin{array}{c}22 \\
\mathrm{~L}_{2} \mathrm{~B}_{2} \\
\end{array}$ & $\begin{array}{c}25 \\
\mathrm{~B}_{2} \mathrm{R}_{2} \\
\end{array}$ & $\begin{array}{c}20 \\
\mathrm{R}_{1} \mathrm{~B}_{1} \\
\end{array}$ & $\begin{array}{c}21 \\
\mathrm{~L}_{1} \mathrm{~B}_{1} \\
\end{array}$ & - Cheapest \\
\hline $\begin{array}{c}24 \\
\mathrm{~B}_{2} \cdot \mathrm{R}_{1} \\
\end{array}$ & $\begin{array}{c}22 \\
\mathrm{~B}_{2} \cdot \mathrm{L}_{2} \\
\end{array}$ & $\begin{array}{c}25 \\
\mathrm{R}_{2} \cdot \mathrm{B}_{2} \\
\end{array}$ & $\begin{array}{c}14 \\
\mathrm{R}_{1} . \mathrm{C} \\
\end{array}$ & $\begin{array}{c}3 \\
\mathrm{~T}_{1} . \mathrm{C} \\
\end{array}$ & $\begin{array}{c}12 \\
\mathrm{~L}_{2} \cdot \mathrm{C} \\
\end{array}$ & $\begin{array}{c}13 \\
\text { C.C } \\
\end{array}$ & $\begin{array}{c}4 \\
\mathrm{~T}_{1} \cdot \mathrm{R}_{1} \\
\end{array}$ & $\begin{array}{c}11 \\
\mathrm{~L}_{1} . \mathrm{C} \\
\end{array}$ & - Premium \\
\hline $\begin{array}{c}22 \\
\mathrm{~B}_{2} \cdot \mathrm{L}_{2}\end{array}$ & $\begin{array}{c}23 \\
\mathrm{~B}_{2} . \mathrm{C}\end{array}$ & $\begin{array}{c}25 \\
\mathrm{R}_{2} \cdot \mathrm{B}_{2}\end{array}$ & $\begin{array}{c}9 \\
\mathrm{R}_{1} \cdot \mathrm{T}_{2}\end{array}$ & $\begin{array}{c}2 \\
\mathrm{~L}_{2} \cdot \mathrm{T}_{1}\end{array}$ & $\begin{array}{c}12 \\
\mathrm{~L}_{2} \cdot \mathrm{C}\end{array}$ & $\begin{array}{c}8 \\
\mathrm{~T}_{2} \cdot \mathrm{C}\end{array}$ & $\begin{array}{c}3 \\
\mathrm{~T}_{1} \mathrm{C}\end{array}$ & $\begin{array}{c}11 \\
\mathrm{~L}_{1} \cdot \mathrm{C}\end{array}$ & - Popular \\
\hline $\begin{array}{c}25 \\
\mathrm{R}_{2} \cdot \mathrm{B}_{2}\end{array}$ & $\begin{array}{c}22 \\
\mathrm{~B}_{2} \cdot \mathrm{C}_{2}\end{array}$ & $\begin{array}{c}23 \\
\mathrm{~B}_{2} . \mathrm{C}\end{array}$ & $\begin{array}{c}6 \\
\mathrm{~L}_{1} . \mathrm{T}_{2}\end{array}$ & $\begin{array}{c}6.8 \\
\mathrm{~T}_{2} . \mathrm{C}\end{array}$ & $\begin{array}{c}7 \\
\mathrm{~T}_{2} \cdot \mathrm{L}_{2}\end{array}$ & $\begin{array}{c}11 \\
\mathrm{~L}_{1} . \mathrm{C}\end{array}$ & $\begin{array}{c}7 \\
\mathrm{~T}_{2} \mathrm{~L}_{2}\end{array}$ & $\begin{array}{c}6 \\
\mathrm{~L}_{1} \mathrm{~T}_{2}\end{array}$ & - Promoted \\
\hline $\begin{array}{c}13 \\
\text { C.C }\end{array}$ & $\begin{array}{c}25 \\
\mathrm{~B}_{2} \cdot \mathrm{R}_{2}\end{array}$ & $\begin{array}{c}23 \\
\mathrm{~B}_{2} \cdot \mathrm{C}\end{array}$ & $\begin{array}{c}11 \\
\text { L.C }\end{array}$ & $\begin{array}{c}7.9 \\
\mathrm{~T}_{2} . \mathrm{L}_{2}\end{array}$ & $\begin{array}{c}9 \\
\mathrm{R}_{1} \mathrm{~T}_{2}\end{array}$ & $\begin{array}{c}23 \\
\mathrm{~B}_{2} \cdot \mathrm{C}\end{array}$ & $\begin{array}{c}11 \\
\mathrm{~L}_{1} . \mathrm{C}\end{array}$ & $\begin{array}{c}13 \\
\text { C.C }\end{array}$ & - Store \\
\hline $\begin{array}{c}12 \\
\mathrm{~L}_{2} \cdot \mathrm{C}\end{array}$ & $\begin{array}{c}25 \\
\mathrm{~B}_{2} \cdot \mathrm{R}_{2} \\
\end{array}$ & $\begin{array}{c}23 \\
\mathrm{~B}_{2} . \mathrm{C}\end{array}$ & $\begin{array}{c}13 \\
\text { C.C }\end{array}$ & $\begin{array}{c}15 \\
\mathrm{R}_{2} . \mathrm{C} \\
\end{array}$ & $\begin{array}{c}12 \\
\mathrm{~L}_{2} \cdot \mathrm{C}\end{array}$ & $\begin{array}{c}23 \\
\mathrm{~B}_{2} . \mathrm{C}\end{array}$ & $\begin{array}{c}12 \\
\mathrm{~L}_{2} \cdot \mathrm{C}\end{array}$ & $\begin{array}{c}10 \\
\mathrm{R}_{1} \mathrm{~T}_{2} \\
\end{array}$ & - Well- Known \\
\hline $\begin{array}{r}17.9 \\
\mathrm{R}_{1} . \mathrm{T}_{2}\end{array}$ & $\begin{array}{c}25 \\
\mathrm{~B}_{2} \cdot \mathrm{R}_{2}\end{array}$ & $\begin{array}{c}25 \\
\mathrm{R}_{2} \cdot \mathrm{B}_{2}\end{array}$ & $\begin{array}{c}8 \\
\mathrm{~T}_{2} \cdot \mathrm{C}\end{array}$ & $\begin{array}{c}6 \\
\mathrm{~L}_{1} \cdot \mathrm{T}_{2}\end{array}$ & $\begin{array}{c}2 \\
\mathrm{~L}_{2} \cdot \mathrm{T}_{1}\end{array}$ & $\begin{array}{c}22 \\
\mathrm{~B}_{2} \cdot \mathrm{L}_{2}\end{array}$ & $\begin{array}{c}3 \\
\mathrm{~T}_{1} \cdot \mathrm{C}\end{array}$ & $\begin{array}{c}1 \\
\mathrm{R}_{1} \mathrm{~T}_{1}\end{array}$ & - New \\
\hline $\begin{array}{c}24 \\
\mathrm{~B}_{2} \cdot \mathrm{R}_{1}\end{array}$ & $\begin{array}{c}8 \\
\mathrm{~T}_{2} \cdot \mathrm{C}\end{array}$ & $\begin{array}{c}23 \\
\mathrm{~B}_{2} \cdot \mathrm{C}\end{array}$ & $\begin{array}{c}15 \\
\mathrm{R}_{2} . \mathrm{C}\end{array}$ & $\begin{array}{c}25 \\
\mathrm{~B}_{2} \cdot \mathrm{R}_{2}\end{array}$ & $\begin{array}{c}22 \\
\mathrm{~L}_{2} \cdot \mathrm{B}_{2}\end{array}$ & $\begin{array}{c}8 \\
\mathrm{~T}_{2} \cdot \mathrm{C}\end{array}$ & $\begin{array}{c}16 \\
\mathrm{~B}_{1} \mathrm{~L}_{1}\end{array}$ & $\begin{array}{c}21 \\
\mathrm{~L}_{1} \mathrm{~B}_{2}\end{array}$ & - Show moving \\
\hline
\end{tabular}


13.3 the results of the $\triangle$ NOVA test for H.13

13.3.1 Customers Horizontal Orientation

Table 27: The results of ANOVA test

Customers Horizontal orientation

\begin{tabular}{|c|c|c|c|c|c|c|c|}
\hline P-Value & F- Value & \multicolumn{2}{|c|}{ Right } & Center & \multicolumn{2}{|c|}{ Left } & Brands \\
\hline \multirow{3}{*}{0,000} & \multirow{3}{*}{5821} & 5 & 4 & $\mathbf{3}$ & 2 & 1 & \multirow{3}{*}{$\begin{array}{c}\text { 1- Cheapest } \\
\text { Mean }\end{array}$} \\
\hline & & 4,762 & 3,1091 & 3,000 & 3,096 & 3,400 & \\
\hline & & 0,1320 & 0,1375 & 0,2146 & 0,3109 & 0,000 & \\
\hline \multirow{2}{*}{0,000} & \multirow{2}{*}{259,26} & 2.6979 & 3.2234 & 3.2490 & 3,1964 & 3,1300 & 2- Premium \\
\hline & & 0,3151 & 0,3241 & 0,2721 & 0,2536 & 0,5347 & St. Dev \\
\hline \multirow{3}{*}{0,000} & \multirow{3}{*}{322,02} & & & & & & 3- Popular \\
\hline & & 2,9026 & 3,7057 & 3,8214 & 3,3594 & 3,0762 & Mean \\
\hline & & 0,4321 & 0,6147 & 0,4320 & 0,2239 & 0,3532 & St. Dev \\
\hline \multirow{2}{*}{0.000} & \multirow{2}{*}{344,16} & 2,6473 & 3,1484 & 3,1969 & 3,5156 & 3,1138 & $\begin{array}{l}\text { 4- Promoted } \\
\text { Mean }\end{array}$ \\
\hline & & 0,2693 & 0,2439 & 0,2002 & 0,1208 & 0,5681 & St.Dev \\
\hline \multirow[b]{2}{*}{0,000} & \multirow[b]{2}{*}{24,60} & & & & & & 5- Store \\
\hline & & $\frac{3,2301}{0,6870}$ & $\begin{array}{l}2,9826 \\
07091\end{array}$ & $\frac{3,0806}{0,5932}$ & $\frac{3,3637}{05953}$ & $\begin{array}{l}3,2721 \\
07352\end{array}$ & $\begin{array}{l}\text { Mean } \\
\text { StDey }\end{array}$ \\
\hline \multirow{3}{*}{0,000} & \multirow{3}{*}{39,33} & & & & & & 6-Well- Known \\
\hline & & 3,1219 & 3,0557 & 3,1814 & 3,2951 & 3,5634 & Mean \\
\hline & & 0,7386 & 0,6599 & 0,5182 & 0,6654 & 0,4965 & St.Dev \\
\hline \multirow[b]{2}{*}{0,000} & \multirow[b]{2}{*}{419,33} & 2,5345 & 3,0776 & 3,7177 & 3,6983 & 2,9112 & $\begin{array}{l}\text { 7- New } \\
\text { Mean }\end{array}$ \\
\hline & & 0,3997 & 0,4974 & 0,6350 & 0,4192 & 0,4744 & St.Dev \\
\hline \multirow[b]{2}{*}{0,000} & \multirow[b]{2}{*}{1070} & 2.0573 & 2.9714 & 4.8609 & 46768 & 3.8816 & 8- Slow- Moving \\
\hline & & 0.3828 & 0.3940 & 0.7350 & 0.4182 & 0.4226 & St. Dev \\
\hline
\end{tabular}

13.3.2 Customer Vertical Orientation

Table 28: The results of ANOVA test

Customers Vertical orientation

\begin{tabular}{|c|c|c|c|c|c|c|c|}
\hline P- Value & F- Value & & & Center & & & Brands \\
\hline \multirow{3}{*}{0,000} & \multirow{3}{*}{1386,62} & 5 & 4 & 3 & 2 & $\mathbf{1}$ & \multirow{2}{*}{$\begin{array}{l}\text { 1- Cheapest } \\
\text { Mean }\end{array}$} \\
\hline & & 2,9911 & 3,285 & 3,882 & 3,7492 & 2,9005 & \\
\hline & & 0,396 & 0,1365 & 0,1673 & 0,2155 & 0,1334 & St. Dev \\
\hline \multirow{2}{*}{0,000} & \multirow[b]{2}{*}{453,37} & 2,9681 & 3,1060 & 3,265 & 3,7321 & 3.0789 & $\begin{array}{l}\text { 2- Premium } \\
\text { Mean }\end{array}$ \\
\hline & & 0,2484 & 0,1918 & 0,448 & 0,3206 & $\begin{array}{l}5,0 / 09 \\
0,5169\end{array}$ & St. Dev \\
\hline \multirow{2}{*}{0,000} & \multirow{2}{*}{517,22} & 3,246 & 2,736 & 3,7240 & 3,3010 & 3,5036 & $\begin{array}{l}\text { 3- Popular } \\
\text { Mean }\end{array}$ \\
\hline & & & & & & & St. Dev \\
\hline \multirow[b]{2}{*}{0,000} & \multirow[b]{2}{*}{463,69} & 3,0224 & 3,115 & 3,1182 & 3,7552 & 29536 & 4- Promoted \\
\hline & & 0,1851 & 0,1819 & 0,2713 & 0,2587 & $\begin{array}{l}2,9530 \\
0,4706 \\
\end{array}$ & St. Dev \\
\hline \multirow[b]{2}{*}{0,000} & \multirow[b]{2}{*}{79,43} & 3,0736 & 3,0114 & 3,527 & 3,396 & 30014 & 5- Store \\
\hline & & 0,420 & 0,809 & 0,443 & 0,3525 & $\begin{array}{c}5,0014 \\
0,524\end{array}$ & St. Dev \\
\hline \multirow{2}{*}{0,000} & \multirow{2}{*}{107,27} & 3,4276 & 3,1810 & 2,895 & 3,0103 & 3.6809 & 6- Well- Known \\
\hline & & 0,4039 & 0,623 & 0,6080 & 0,8062 & $\begin{array}{l}0,0007 \\
0,4023 \\
\end{array}$ & St. Dev \\
\hline \multirow{2}{*}{0,000} & \multirow{2}{*}{389,02} & 3,1479 & 2,9316 & 2,8307 & 3,8906 & 2947 & $\begin{array}{l}\text { 7- New } \\
\text { Mean }\end{array}$ \\
\hline & & 0,3604 & 0,3421 & 0,532 & 0,3638 & 0,4987 & St. Dev \\
\hline \multirow{2}{*}{0,000} & \multirow{2}{*}{45,26} & 3,720 & 3,773 & 3,680 & 3,5578 & 3.6849 & $\begin{array}{l}\text { 8- Slow- Moving } \\
\text { Mean }\end{array}$ \\
\hline & & 0,2206 & 0,1193 & 0,253 & 0,1272 & $\begin{array}{l}J, 00+7 \\
0,3059\end{array}$ & St. Dev \\
\hline
\end{tabular}


13.3.3 Store manages Horizontal Orientation

Table 29: The results of ANOVA test

Store managers Horizontal Orientation

\begin{tabular}{|c|c|c|c|c|c|c|c|}
\hline P- Value & F- Value & \multicolumn{2}{|c|}{ Right } & Center & \multicolumn{2}{|c|}{ Left } & Brands \\
\hline \multirow{3}{*}{0,000} & \multirow{3}{*}{438,45} & 5 & 4 & 3 & 2 & 1 & \multirow{2}{*}{$\begin{array}{l}\text { 1- Cheapest } \\
\text { Mean }\end{array}$} \\
\hline & & 4,6960 & 3,1240 & 2,800 & 3,1020 & 3,0760 & \\
\hline & & 0,2126 & 0,2074 & 0,2040 & 0,3023 & 0,3368 & St. Dev \\
\hline \multirow[t]{2}{*}{0,000} & \multirow[t]{2}{*}{142,72} & 3,0824 & 3.6824 & 3,9059 & 3,3961 & 3,0941 & 2- $\begin{array}{l}\text { Premium } \\
\text { Mean }\end{array}$ \\
\hline & & 0,3025 & 0,3025 & 0,1008 & 0,1766 & 0,1008 & St. Dev \\
\hline \multirow{2}{*}{0,000} & \multirow{2}{*}{83,82} & 3.7240 & 3,5520 & 3.880 & 3,2080 & 2,4840 & $\begin{array}{l}\text { 3- Popular } \\
\text { Mean }\end{array}$ \\
\hline & & 0,6751 & 0,2138 & 0,1851 & 0,2992 & 0,2745 & St. Dev \\
\hline \multirow[t]{2}{*}{0,000} & \multirow[t]{2}{*}{53,63} & 2,6300 & 3,1560 & 3,9560 & 3,5120 & 3,1280 & $\begin{array}{l}\text { 4- Promoted } \\
\text { Mean }\end{array}$ \\
\hline & & 0,2640 & 0,2376 & 0,4182 & 0,2123 & 0,5611 & St. Dev \\
\hline \multirow{2}{*}{0,000} & \multirow{2}{*}{44,88} & 2.9160 & 2,4120 & 3.0120 & 2,6200 & 3,3640 & $\begin{array}{l}\text { 5- Store } \\
\text { Mean }\end{array}$ \\
\hline & & & 0,3109 & 0,2873 & 0,4787 & 0,3659 & St. Dev \\
\hline \multirow{2}{*}{0,001} & \multirow{2}{*}{5} & 20578 & 20400 & 3775 & 32667 & 32078 & 6- Well- Known \\
\hline & & 0,7442 & 0,5540 & 0,6396 & 0,2733 & 0,7200 & St. Dev \\
\hline \multirow{2}{*}{0,000} & \multirow{2}{*}{7,61} & 3.000 & 3.0840 & 3.2691 & 3.5882 & 3,3640 & 7- New \\
\hline & & 0,7031 & 0,2915 & 0,6892 & 0,4405 & 0,7565 & St. Dev \\
\hline \multirow{2}{*}{0,000} & \multirow{2}{*}{48,42} & 3,0280 & 3,2920 & 3,8680 & 2,9525 & 2,5477 & $\begin{array}{l}\text { 8-Slow- Moving } \\
\text { Mean }\end{array}$ \\
\hline & & 0,4327 & 0,6954 & 0,2652 & 0,4637 & 0,4303 & St. Dev \\
\hline
\end{tabular}

13.3.4 Store Manager Vertical Orientation

Table 30: The results of ANOVA test

Store managers Vertical orientation

\begin{tabular}{|c|c|c|c|c|c|c|c|}
\hline P- Value & F- Value & \multicolumn{2}{|c|}{ Bottom } & Center & \multicolumn{2}{|c|}{ Top } & Brands \\
\hline \multirow{3}{*}{0,000} & \multirow{3}{*}{123,34} & 5 & 4 & $\mathbf{3}$ & 2 & 1 & \multirow{2}{*}{$\begin{array}{l}\text { 1- Cheapest } \\
\text { Mean }\end{array}$} \\
\hline & & 2,9920 & 3,2860 & 3,9280 & 3,8160 & 2,9000 & \\
\hline & & 0,3959 & 0,1414 & 0,2324 & 0,4628 & 0,1000 & St. Dev \\
\hline \multirow{2}{*}{0,000} & \multirow{2}{*}{67,92} & 2.5959 & 3.1218 & 4.1918 & 3.4939 & 3.9551 & $\begin{array}{c}\text { 2- Premium } \\
\text { Mean }\end{array}$ \\
\hline & & 0,1979 & 0,2516 & 0,1598 & 0,2969 & 0,1567 & St. Dev \\
\hline \multirow{2}{*}{0,000} & \multirow{2}{*}{59,15} & 3,2200 & 2,7720 & 4,1000 & 2,9080 & 3,3560 & $\begin{array}{l}\text { 3- Popular } \\
\text { Mean }\end{array}$ \\
\hline & & 0,6989 & 0,2227 & 0,2569 & 0,6838 & 0,3001 & St. Dev \\
\hline \multirow[t]{2}{*}{0,000} & \multirow[t]{2}{*}{65,30} & 3,6246 & 3,1120 & 3,1259 & 3,7640 & 2,9600 & $\begin{array}{l}\text { 4- Promoted } \\
\text { Mean }\end{array}$ \\
\hline & & 0,1773 & 0,1840 & 0,2674 & 0,2520 & 0,4578 & St. Dev \\
\hline \multirow{2}{*}{0,000} & \multirow{2}{*}{151,85} & 3,8000 & 2,8760 & 2,6530 & 2,5320 & 2,4600 & $\begin{array}{l}\text { 5- Store } \\
\text { Mean }\end{array}$ \\
\hline & & 0,000 & 0,4881 & 0,3288 & 0,3432 & 0,1929 & St. Dev \\
\hline \multirow[t]{2}{*}{0,000} & \multirow[t]{2}{*}{21,64} & 3,0627 & 3,0971 & 3,7020 & 3,1961 & 2,8353 & $\begin{array}{l}\text { 6- Well- Known } \\
\text { Mean }\end{array}$ \\
\hline & & 0,4907 & 0,7172 & 0,2694 & 0,2870 & 0,5516 & St. Dev \\
\hline \multirow{2}{*}{0,000} & \multirow{2}{*}{21,85} & 3,666 & 3,0147 & 2,8471 & 3,1265 & 3,7765 & $\begin{array}{c}\text { 7- New } \\
\text { Mean }\end{array}$ \\
\hline & & 0,3637 & 0,8345 & 0,7262 & 0,7352 & 0,2818 & St. Dev \\
\hline \multirow{2}{*}{0,000} & \multirow{2}{*}{31,24} & 3,1412 & 2,9451 & 2,8000 & 3,9490 & 3,014 & $\begin{array}{l}\text { 8- Slow- Moving } \\
\text { Mean }\end{array}$ \\
\hline & & 0,3694 & 0,4374 & 0,6171 & 0,5167 & 0,3345 & St. Dev \\
\hline
\end{tabular}


13.3.5 Operations \& Commercial Department Managers Horizontal Orientation Table 31: The results of ANOVA test

Operations \& Commercial Department managers' Horizontal orientation

\begin{tabular}{|c|c|c|c|c|c|c|c|}
\hline P- Value & F- Value & \multicolumn{2}{|c|}{ Right } & Center & \multicolumn{2}{|c|}{ Left } & Brands \\
\hline \multirow{3}{*}{0,000} & \multirow{3}{*}{220,57} & 5 & 4 & 3 & 2 & 1 & \multirow[b]{2}{*}{$\begin{array}{l}\text { 1- Cheapest } \\
\text { Mean }\end{array}$} \\
\hline & & 2,9550 & 3,8950 & 4,3900 & 3,0856 & 1,9238 & \\
\hline & & 0,3962 & 0,3435 & 0,5366 & 0,3373 & 0,3965 & St. Dev \\
\hline \multirow{2}{*}{0,000} & \multirow{2}{*}{684,96} & 39000 & 48000 & 47000 & 27850 & 22500 & 2- Premium \\
\hline & & 0,2530 & 0,2726 & 0,3550 & 0,2505 & 0,2480 & St. Dev \\
\hline \multirow{3}{*}{0,000} & \multirow{3}{*}{584,24} & & & & & & 3- Popular \\
\hline & & 3,8150 & 4,7650 & 4,7100 & 2,7000 & 2,1300 & Mean \\
\hline & & 0,3258 & 0,2824 & 0,3713 & 0,2720 & 0,3018 & St. Dev \\
\hline \multirow{2}{*}{0,000} & \multirow{2}{*}{519,59} & 3,7950 & 4,7250 & 4,6950 & 2.6750 & 2.1200 & 4- Promoted \\
\hline & & 0,3478 & 0,2956 & 0,3898 & 0,3023 & 0,3092 & St. Dev \\
\hline \multirow{3}{*}{0,000} & \multirow{3}{*}{106,68} & & & & & & 5- Store \\
\hline & & 2,0600 & 2,9700 & 4,8300 & 4,4950 & 3,8800 & Mean \\
\hline & & 0,1428 & 0,2027 & 0,2390 & 0,2323 & 0,2993 & St. Dev \\
\hline \multirow[t]{2}{*}{0,000} & \multirow[t]{2}{*}{1073,23} & 2,0200 & 4,000 & 4,8600 & 4,6700 & 4,005 & $\begin{array}{l}\text { 6- Well- Known } \\
\text { Mean }\end{array}$ \\
\hline & & 0,166 & 0,1949 & 0,2059 & 0,3084 & 0,1974 & St. Dev \\
\hline \multirow{2}{*}{0,000} & \multirow{2}{*}{840,38} & & 20800 & 47550 & 1550 & 48200 & 7- New \\
\hline & & $\begin{array}{l}2,1250 \\
0,2083\end{array}$ & $\begin{array}{l}2,9000 \\
0,2482\end{array}$ & $\begin{array}{l}4,7550 \\
0,3478\end{array}$ & $\begin{array}{l}4,1550 \\
0,2024\end{array}$ & $\begin{array}{l}4,8200 \\
0,2676\end{array}$ & $\begin{array}{l}\text { Mean } \\
\text { St. Dev }\end{array}$ \\
\hline \multirow{2}{*}{0,000} & \multirow{2}{*}{153113} & 30050 & & & & & 8-Slow- Moving \\
\hline & & $\frac{5,0050}{0,6205}$ & $\begin{array}{c}5,990 \\
0,2234\end{array}$ & $\frac{4,217}{0,2289}$ & $\begin{array}{l}4,0000 \\
0,3033\end{array}$ & $\frac{3,8900}{0,2681}$ & $\begin{array}{l}\text { Mean } \\
\text { St. Dev }\end{array}$ \\
\hline
\end{tabular}

13.3.6. Operations \& commercial department manger Vertical orientation

Table 32: The results of ANOVA test

Operations \& commercial department manager Vertical orientation

\begin{tabular}{|c|c|c|c|c|c|c|c|}
\hline P- Value & F- Value & & $\mathbf{m}$ & Center & 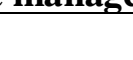 & 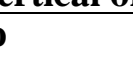 & Brands \\
\hline \multirow{3}{*}{0,000} & \multirow{3}{*}{13,86} & 5 & 4 & 3 & 2 & 1 & \multirow[b]{2}{*}{$\begin{array}{l}\text { 1- Cheapest } \\
\text { Mean }\end{array}$} \\
\hline & & 28750 & 3,4600 & 3,2838 & 342000 & 3,3800 & \\
\hline & & 0,3706 & 0,3826 & 0,4081 & 0,4285 & 0,449 & St. Dev \\
\hline \multirow{3}{*}{0,000} & \multirow{3}{*}{5,83} & & & & & & 2- Premium \\
\hline & & 3,7019 & 3,8800 & 3,6550 & 3,6050 & 3,6900 & Mean \\
\hline & & 0,1284 & 0,2561 & 0,2828 & 0,3962 & 0,2488 & St. Dev \\
\hline \multirow{2}{*}{0,509} & \multirow{2}{*}{0,83} & 36960 & 37130 & 36550 & 36250 & 3600 & 3- Popular \\
\hline & & $\begin{array}{l}5,0900 \\
0,2353\end{array}$ & $\frac{5, / 159}{0,3253}$ & $\begin{array}{l}3,0 J 30 \\
0,3193\end{array}$ & $\begin{array}{l}0,0250 \\
0,4005\end{array}$ & $\begin{array}{c}5,000 \\
0,3688\end{array}$ & St. Dev \\
\hline \multirow{2}{*}{0,874} & \multirow{2}{*}{0,31} & 36381 & 36700 & 36550 & 36250 & 3600 & 4- Promoted \\
\hline & & $\begin{array}{l}0,0501 \\
0,1567\end{array}$ & 0,2590 & $\frac{0,3193}{0,030}$ & $\frac{0,4005}{0,405}$ & 0,3688 & St. Dev \\
\hline \multirow{3}{*}{0,761} & \multirow{3}{*}{0,47} & & & & & & 5- Store \\
\hline & & 3,6160 & 3,6700 & 3,6300 & 3,6200 & 3,570 & Mean \\
\hline & & 0,1659 & 0,2590 & 0,3480 & 0,3995 & 0,3638 & St. Dev \\
\hline \multirow{2}{*}{0,001} & \multirow{2}{*}{5,20} & 36641 & 37750 & 36750 & 35600 & 36850 & 6- Well- Known \\
\hline & & $\begin{array}{l}50041 \\
0,1025\end{array}$ & $\frac{5,1130}{0,119}$ & 0,2557 & $\begin{array}{l}0,2154 \\
0,2154\end{array}$ & $\begin{array}{l}0,0030 \\
0,3062\end{array}$ & St. Dev \\
\hline \multirow{3}{*}{0,687} & \multirow{3}{*}{0,57} & & & & & & 7- New \\
\hline & & 3,9700 & 3,9267 & 3,9900 & 3,9150 & 3,9350 & Mean \\
\hline & & 0,276 & 0,1097 & 0,1718 & 0,1838 & 0,2163 & St. Dev \\
\hline \multirow{3}{*}{0,000} & \multirow{3}{*}{5,27} & & & & & & 8- Slow- Moving \\
\hline & & 3,7487 & 3,8050 & 3,600 & 3,5150 & 3,4475 & Mean \\
\hline & & 0,1256 & 0,2241 & 0,4362 & 0,5066 & 0,5987 & St. Dev \\
\hline
\end{tabular}


13.3.7 Comparison among the groups of respondents with regard to the Horizontal Shelf Space position- left side hand

Table 33: The results of the ANOVA test

For H: 13 A comparison among all groups with regard to the

Horizontal shelf space positions, left side hand

\begin{tabular}{|c|c|c|c|c|c|c|c|c|c|c|c|c|c|c|}
\hline \multirow[b]{3}{*}{ P- Value } & \multirow[b]{3}{*}{ F- Value } & \multicolumn{4}{|c|}{$\begin{array}{l}\text { Store Managers } \\
\mathrm{n}=\mathbf{5 1}\end{array}$} & \multicolumn{4}{|c|}{$\begin{array}{c}\text { Customers } \\
n=384\end{array}$} & \multicolumn{4}{|c|}{$\begin{array}{c}\text { Operations \& Commercial } \\
\text { department managers } \\
n=41\end{array}$} & \multirow{3}{*}{ Brands } \\
\hline & & \multicolumn{2}{|c|}{ Left 2} & \multicolumn{2}{|c|}{ Left 1} & \multicolumn{2}{|c|}{ Left 2} & \multicolumn{2}{|c|}{ Left 1} & \multicolumn{2}{|c|}{ Left 2} & \multicolumn{2}{|c|}{ Left 1} & \\
\hline & & St.Dev & Mean & St.Dev & Mean & St.Dev & Mean & St.Dev & Mean & St.Dev & Mean & St.Dev & Mean & \\
\hline 0,000 & 284,69 & 0,3023 & 3,1020 & 0,3368 & 3,0760 & 0,1305 & 3,0956 & 0,000 & 3,4000 & 0,3373 & 3,0850 & 0,3965 & 1,9238 & - Cheapest \\
\hline 0,000 & 106,30 & 0,1737 & 3,3959 & 0,1000 & 3,0980 & 0,2536 & 3,4964 & 0,5347 & 3,1300 & 0,2537 & 2,7850 & 0,2512 & 2,2500 & - Premium \\
\hline 0,000 & 210 & 0,2123 & 3,5120 & 0,5611 & 3,1280 & 0,2239 & 3,3594 & 0,3532 & 3,8762 & 0,2720 & 2,700 & 0,3018 & 2,1300 & - Popular \\
\hline 0,000 & 118,70 & 0,2123 & 3,5120 & 0,5611 & 3,1280 & 0,21081 & 3,5156 & 0,5681 & 3,1138 & 0,3023 & 2,6750 & 0,3092 & 2,1200 & - Promoted \\
\hline 0,000 & 83,57 & 0,4836 & 2,6200 & 0,3696 & 3,3640 & 0,5941 & 3,3678 & 0,3753 & 3,2719 & 0,2323 & 4,4950 & 0,2993 & 3,8800 & - Store \\
\hline 0,000 & 76,22 & 0,2754 & 3,2640 & 0,7273 & 3,2080 & 0,5953 & 3,3637 & 0,3753 & 3,2721 & 0,3084 & 4,6700 & 0,1974 & 4,6050 & - Well- Known \\
\hline 0,000 & 219,19 & 0,4385 & 3,5820 & 0,7494 & 3,3610 & 0,4326 & 3,6931 & 0,4743 & 2,9111 & 0,2024 & 4,1550 & 0,2676 & 4,8200 & - New \\
\hline 0,000 & 832,26 & 0,4637 & 2,9525 & 0,4303 & 2,5477 & 0,2510 & 4,6766 & 0,2729 & 3,8816 & 0,3033 & 4,6000 & 0,2681 & 3,2900 & - Slow moving \\
\hline
\end{tabular}


13.3.8 Comparison among the three groups of respondents with regard to Horizontal Central position

Table 34: The results of the ANOVA Test

For H. 13 A comparison among

The three groups of respondents with regard to

Horizontal Central positions

\begin{tabular}{|c|c|c|c|c|c|c|c|l|}
\hline & & \multicolumn{2}{|c|}{$\begin{array}{c}\text { Store Managers } \\
\mathbf{n = ~ 5 1}\end{array}$} & \multicolumn{2}{c|}{$\begin{array}{c}\text { Customers } \\
\text { n= 384 }\end{array}$} & \multicolumn{2}{c|}{$\begin{array}{c}\text { Operations \& Commercial } \\
\text { department managers } \\
\text { n= 41 }\end{array}$} & Mean \\
\hline P- Value & F-Value & St. Dev & Mean & St. Dev & Mean & St. Dev & Brands \\
\hline 0,000 & 580,95 & 0,2040 & 2,8000 & 0,2146 & 3,0000 & 0,5366 & 4,3900 & $\bullet$ Cheapest \\
\hline 0,000 & 629,72 & 0,0990 & 3,9025 & 0,2718 & 3,2489 & 0,3550 & 4,7000 & $\bullet$ Premium \\
\hline 0,000 & 125,06 & 0,1851 & 3,3880 & 0,4314 & 3,8214 & 0,3713 & 4,7100 & $\bullet$ Popular \\
\hline 0,000 & 76,63 & 0,4182 & 3,5560 & 0,2000 & 3,1969 & 0,4182 & 3,5560 & $\bullet$ Promoted \\
\hline 0,000 & 194,65 & 0,2873 & 3,0120 & 0,5924 & 3,0806 & 0,2390 & 4,8300 & $\bullet$ Store \\
\hline 0,000 & 78,61 & 0,8288 & 3,3592 & 0,6342 & 3,7177 & 0,2054 & 4,8600 & $\bullet$ Well- Known \\
\hline 0,000 & 19,40 & 0,6892 & 3,2691 & 0,6350 & 3,7177 & 0,6892 & 3,2691 & $\bullet$ New \\
\hline 0,000 & 479,46 & 0,2652 & 3,8080 & 0,2230 & 4,8609 & 0,2289 & 4,7750 & $\bullet$ Slow moving \\
\hline
\end{tabular}




\subsubsection{Comparison among the three groups of respondents with regard to the Horizontal orientation, right positions}

Table 35: The results of the ANOVA Test

For H: 13 A comparison among the three group of respondents with regard

the Horizontal orientation, right positions

\begin{tabular}{|c|c|c|c|c|c|c|c|c|c|c|c|c|c|c|}
\hline \multirow[b]{3}{*}{ P- Value } & \multirow[b]{3}{*}{ F- Value } & \multicolumn{4}{|c|}{$\begin{array}{l}\text { Store Managers } \\
\qquad \mathrm{n}=\mathbf{5 1}\end{array}$} & \multicolumn{4}{|c|}{$\begin{array}{c}\text { Customers } \\
n=384\end{array}$} & \multicolumn{4}{|c|}{$\begin{array}{c}\text { Operations \& Commercial } \\
\text { department managers } \\
n=41\end{array}$} & \multirow[b]{3}{*}{ Brands } \\
\hline & & \multicolumn{2}{|c|}{ Right 2} & \multicolumn{2}{|c|}{ Right 1} & \multicolumn{2}{|c|}{ Right 2} & \multicolumn{2}{|c|}{ Right 1} & \multicolumn{2}{|c|}{ Right 2} & \multicolumn{2}{|c|}{ Right 1} & \\
\hline & & St. Dev & Mean & St. Dev & Mean & St. Dev & Mean & St. Dev & Mean & St. Dev & Mean & St. Dev & Mean & \\
\hline 0,000 & 598 & 0462 & 3,816 & 0,1000 & 2,9000 & 0,2144 & 3,7496 & 0,133 & 2,900 & 0,4285 & 3,4200 & 0,4490 & 3,3800 & - Cheapest \\
\hline 0,000 & 85 & 0,299 & 3,4939 & 0,1685 & 3,9551 & 0,3302 & 3,7321 & 0,1516 & 3,0789 & 0,3962 & 3,650 & 0,2488 & 3,6900 & - Premium \\
\hline 0,000 & 13,44 & 06838 & 2,908 & 0,3001 & 3,3560 & 0,573 & 3,3061 & 0,4056 & 3,6250 & 0,4056 & 3,6250 & 0,3735 & 3,600 & - Popular \\
\hline 0,000 & 28,92 & 0250 & 3,76 & 0,45 & 2,9600 & 0,258 & 3,755 & 047 & 2,953 & 0,3995 & 3,62 & 3638 & 3,575 & - Promoted \\
\hline 0,000 & 106,91 & 0,343 & 2,532 & 0,1929 & 2,46 & 0,352 & 3,395 & 0,524 & 3,00 & 0,215 & 3,560 & 0,306 & 3,6856 & - Store \\
\hline 0,000 & 90,5 & 0,2870 & 3,196 & 0,513 & 2,8052 & 0,806 & 3,0103 & 0,4023 & 3,6609 & 0,806 & 3,0103 & 0,4023 & 3,6609 & - Well- Known \\
\hline 0,000 & 244,13 & 0,7177 & 3,101 & 0,267 & 3,764 & 0,498 & 2,947 & 0,4987 & 2,947 & 0,3638 & 3,889 & 0,4981 & 3,947 & - New \\
\hline 0,000 & 71,43 & 0,5162 & 3,952 & 0,815 & 2,987 & 0,516 & 3,952 & 0,8158 & 2,987 & 0,217 & 3,557 & 0,3055 & 3,684 & - Slow - moving \\
\hline
\end{tabular}


13.3.10. Comparison among the three groups of respondents with regard to the Vertical orientation, Top positions

Table 36: The results of the ANOVA Test.

For H: 13 comparison among the three groups of respondents with regard to

the Vertical orientation, Top positions

\begin{tabular}{|c|c|c|c|c|c|c|c|c|c|c|c|c|c|c|}
\hline \multirow[b]{3}{*}{ P-Value } & \multirow[b]{3}{*}{ F- Value } & \multicolumn{4}{|c|}{$\begin{array}{l}\text { Store Managers } \\
\qquad \mathrm{n}=51\end{array}$} & \multicolumn{4}{|c|}{$\begin{array}{c}\text { Customers } \\
n=384\end{array}$} & \multicolumn{4}{|c|}{$\begin{array}{c}\begin{array}{c}\text { Operations \& Commercial } \\
\text { department managers } \\
n=41\end{array} \\
\end{array}$} & \multirow[b]{3}{*}{ Brands } \\
\hline & & Top & 2 & \multicolumn{2}{|c|}{ Top } & \multicolumn{2}{|c|}{ Top } & \multicolumn{2}{|c|}{ Top } & \multicolumn{2}{|c|}{ Top 2} & \multicolumn{2}{|c|}{ Top } & \\
\hline & & St. Dev & Mean & St. Dev & Mean & St. Dev & Mean & St. Dev & Mean & St. Dev & Mean & St. Dev & Mean & \\
\hline 0,000 & 597,7 & 0,2148 & 3,7503 & 0,1302 & 2,8979 & 0,462 & 3,816 & 0,100 & 2,900 & 0,4285 & 3,4200 & 6,4490 & 3,3800 & - Cheapest \\
\hline 0,000 & 85,10 & 0,3478 & 3,4685 & 0,1593 & 3,9442 & 0,3201 & 3,733 & 0,5187 & 3,0769 & 0,3925 & 3,6096 & 0,2463 & 3,6900 & - Premium \\
\hline 0,000 & 22,32 & 0,6929 & 2,9433 & 0,3001 & 3,3560 & 0,5727 & 3,3019 & 0,2249 & 3,4998 & 0,4005 & 3,6250 & 0,3688 & 3,600 & - Popular \\
\hline 0,000 & 189,35 & 0,3140 & 3,7326 & 0,4726 & 2,9325 & 0,2631 & 3,7527 & 0,4745 & 2,9594 & 0,4024 & 3,6105 & 0,3674 & 3,5794 & - Promoted \\
\hline 0,000 & 105,81 & 0,3488 & 2,5438 & 01816 & 2,4678 & 0,3548 & 3,4035 & 0,2181 & 3,002 & 0,218 & 3,550 & 0,3096 & 3,6821 & - Store \\
\hline 0,000 & 65,16 & 0,2978 & 3,1882 & 0,5365 & 2,8366 & 0,8007 & 3,0209 & 0,4166 & 3,6442 & 0,1841 & 3,9101 & 0,217 & 3,9301 & - Well- Known \\
\hline 0,000 & 155,58 & 0,7366 & 3,1366 & 0,3110 & 3,7365 & 0,4146 & 3,8618 & 0,5120 & 2,9664 & 0,2285 & 3,6872 & 0,2888 & 3,7231 & - New \\
\hline 0,000 & 67,60 & 0,5175 & 3,9430 & 0,8222 & 2,9951 & 0,244 & 3,5849 & 0,379 & 3,6227 & 0,2669 & 4,1342 & 0,2565 & 4,0911 & - Slow moving \\
\hline
\end{tabular}


13.3.11. A comparison of the three groups of respondent with regard to Vertical Central orientation

Table 37: The results of the ANOVA Test

For $H: 13$ A comparison of the three groups of respondent

with regard to Vertical Central orientation

\begin{tabular}{|c|c|c|c|c|c|c|c|c|}
\hline \multirow[b]{2}{*}{ P-Value } & \multirow[b]{2}{*}{ F-Value } & \multicolumn{2}{|c|}{$\begin{array}{c}\text { Store Managers } \\
\qquad=\mathbf{5 1}\end{array}$} & \multicolumn{2}{|c|}{$\begin{array}{c}\text { Customers } \\
\mathbf{n}=\mathbf{3 8 4}\end{array}$} & \multicolumn{2}{|c|}{$\begin{array}{l}\text { Operations \& Commercial } \\
\text { department managers } \\
n=41\end{array}$} & \multirow[b]{2}{*}{ Brands } \\
\hline & & St. Dev & Mean & St. Dev & Mean & St. Dev & Mean & \\
\hline 0,915 & 0,09 & 0,5049 & 4,4902 & 0,5061 & 4,487 & 0,529 & 4,4635 & - Cheapest \\
\hline 0,831 & 0,19 & 0,5095 & 4,3137 & 0,5215 & 4,3171 & 0,5196 & 4,2786 & - Premium \\
\hline 0,227 & 1,49 & 0,2715 & 2,9216 & 0,2727 & 3,0244 & 0,4560 & 3,0313 & - Popular \\
\hline 0,768 & 0,26 & 0,4686 & 1,6863 & 0,448 & 1,7317 & 0,5177 & 1,6719 & - Promoted \\
\hline 0,273 & 1,30 & 0,4602 & 1,7059 & 0,5049 & 1,5366 & 0,5196 & 1,6094 & - Store \\
\hline 0,469 & 0,76 & 0,5041 & 4,5294 & 0,5049 & 4,4634 & 0,5071 & 4,4375 & - Well- Known \\
\hline 0,416 & 0,88 & 0,4931 & 4,3922 & 0,5024 & 4,4390 & 0,4962 & 4,3411 & - New \\
\hline 0,298 & 1,22 & 0,3850 & 2,8235 & 0,2637 & 2,9268 & 0,3578 & 2,8984 & - Slow moving \\
\hline
\end{tabular}


13.3.12. A comparison among the three groups of respondents with regard to Bottom shelf space positions

Table 38: The results of the ANOVA Test

for $H$ : 13 A comparison among

Among the three groups of respondents with regard

To Bottom shelf space positions

\begin{tabular}{|c|c|c|c|c|c|c|c|c|c|c|c|c|c|c|}
\hline \multirow[t]{3}{*}{ P- Value } & \multirow[t]{3}{*}{ F- Value } & \multicolumn{4}{|c|}{ Store Managers } & \multicolumn{4}{|c|}{ Customers } & \multicolumn{4}{|c|}{$\begin{array}{l}\text { Operation \& Commercial } \\
\text { department managers }\end{array}$} & \multirow{3}{*}{ Brands } \\
\hline & & \multicolumn{2}{|c|}{ Bottom 2} & \multicolumn{2}{|c|}{ Bottom 1} & \multicolumn{2}{|c|}{ Bottom 2} & \multicolumn{2}{|c|}{ Bottom 1} & \multicolumn{2}{|c|}{ Bottom 2} & \multicolumn{2}{|c|}{ Bottom 1} & \\
\hline & & St.Dev & Mean & St.Dev & Mean & St.Dev & Mean & St.Dev & Mean & St.Dev & Mean & St.Dev & Mean & \\
\hline 0,000 & 26,82 & 0,3959 & 2,9920 & 0,1414 & 3,2860 & 0,1949 & 3,1091 & 0,3957 & 2,9917 & 0,3706 & 2,8750 & 0,3826 & 3,4600 & - Cheapest \\
\hline 0,000 & 395,58 & 0,2059 & 2,6236 & 0,100 & 3,1000 & 6,1588 & 2,7385 & 0,2509 & 2,9657 & 0,1284 & 3,7019 & 2,561 & 3,88 & - Premium \\
\hline 0,000 & 93,08 & 0,6989 & 3,22 & 0,2285 & 2,7759 & 0,1840 & 3,1087 & 0,2167 & 3,2452 & 0,1570 & 3,6396 & 0,2611 & 3,6751 & - Popular \\
\hline 0,000 & 20,41 & 0,2079 & 3,0397 & 0,1880 & 3,1159 & 0,8060 & 3,0140 & 0,1850 & 3,0246 & 0,1659 & 3,6166 & 0,2590 & 3,6700 & - Promoted \\
\hline 0,000 & 41,50 & 0,0840 & 3,7882 & 0,5172 & 2,8917 & 0,6269 & 3,1747 & 0,4194 & 3,0761 & 0,1025 & 3,6641 & 0,1199 & 3,7750 & - Store \\
\hline 0,000 & 112,70 & 0,5075 & 3,0797 & 0,7001 & 3,0849 & 0,3533 & 2,9396 & 0,4065 & 34221 & 0,1107 & 3,9254 & 0,2102 & 3,9693 & - Well- Known \\
\hline 0,000 & 162,78 & 0,3606 & 3,6600 & 0,8158 & 2,9873 & 0,1843 & 3,7514 & 0,3609 & 3,1496 & 0,1335 & 3,7549 & 0,2273 & 3,7772 & - New \\
\hline 0,000 & 214,50 & 0,3370 & 3,1200 & 0,4239 & 2,9337 & 0,2372 & 3,7082 & 0,1843 & 3,7514 & 0,1700 & 4,0731 & 0,2171 & 4,0950 & - Slow moving \\
\hline
\end{tabular}

